\title{
EFEITOS DA ATMOSFERA MODIFICADA E DA IRRADIAÇÃO SOBRE AS CARACTERÍSTICAS MICROBIOLÓGICAS, FÍSICO-QUÍMICAS E SENSORIAIS DO QUEIJO MINAS FRESCAL
}

\author{
VANessa Pires Da Rosa
}

Orientador: Prof. Dr. ERNANI PORTO

\begin{abstract}
Dissertação apresentada à Escola Superior de Agricultura "Luiz de Queiroz", Universidade de São Paulo, para obtenção do título de mestre em Ciências, Área de Concentração: Ciência e Tecnologia de Alimentos.
\end{abstract}

P I R A C I C A B A

Estado de São Paulo - Brasil

Abril - 2004 


\title{
EFEITOS DA ATMOSFERA MODIFICADA E DA IRRADIAÇÃO SOBRE AS CARACTERÍSTICAS MICROBIOLÓGICAS, FÍSICO-QUÍMICAS E SENSORIAIS DO QUEIJO MINAS FRESCAL
}

\author{
VANessa PiRes Da Rosa \\ Bacharel em Química de Alimentos
}

Dissertação apresentada à Escola Superior de Agricultura "Luiz de Queiroz", Universidade de São Paulo, para obtenção do título de mestre em Ciências, Área de Concentração: Ciência e Tecnologia de Alimentos.

\author{
P I R A C I C A B A \\ Estado de São Paulo - Brasil \\ Abril - 2004
}




\section{Dados Internacionais de Catalogação na Publicação (CIP) DIVISÃO DE BIBLIOTECA E DOCUMENTAÇÃO - ESALQ/USP}

Rosa, Vanessa Pires da

Efeitos da atmosfera modificada e da irradiação sobre as características microbiológicas, físico-químicas e sensoriais do queijo Minas Frescal / Vanessa Pires da Rosa. - - Piracicaba, 2004.

$141 \mathrm{p}$.

Dissertação (mestrado) - - Escola Superior de Agricultura Luiz de Queiroz, 2004. Bibliografia.

1. Análise físico-química 2. Análise sensorial 3. Armazenagem em atmosfera modificada 4. Irradiação de alimentos 5. Microbiologia de alimentos 6. Queijo Staphylococcus I. Título

CDD 637.353 
Aos meus pais, Paulo Caldeira da Rosa e Valdeci Pires da Rosa, exemplos de vida, amor e felicidade, meus melhores amigos, a quem devo tudo que hoje sou,

\section{Dedico e Ofereço}




\section{AGRADECIMENTOS}

Ao meu orientador, Prof. Dr. Ernani Porto, pela amizade, apoio, orientação, ensinamentos, dedicação e incentivo durante toda a realização deste trabalho.

À Escola Superior de Agricultura "Luiz de Queiroz" (ESALQ/USP), em especial ao Departamento de Agroindústria, Alimentos e N Nutrição pela oportunidade para realização deste trabalho.

À Coordenadoria de Aperfeiçoamento do Pessoal de Ensino Superior (CAPES), pela bolsa de estudos concedida durante o curso de mestrado.

À Profa. Dra Marta Helena Fillet Spoto pela orientação e incentivo nas análises sensoriais. trabalho.

À Profa. Dra. Marília Oetterer, pelo apoio e incentivo na realização deste

Ao Instituto de Tecnologia de Alimentos (ITAL), em especial a pesquisadora Claire Sarantópoulos, pelo apoio na realização da atmosfera modificada.

A Companhia Brasileira de Esterilização (CBE), pela irradiação do produto.

À técnica do laboratório de laticínios Cleomar Carvalho, pela amizade, apoio e incentivo na realização deste trabalho.

Aos estagiários Mário Paiva e Débora pela amizade e apoio na realização deste trabalho. 
As grandes amigas Cláudia Marinho, Márcia D’vila e Nina Hagen, pela inesquecivel convivência durante o mestrado.

Aos colegas de mestrado Cristiane Feninam, Camila Angerami, Márcia Harada, Laurentina Perdigão e Nilo Martins, pela amizade e pelos momentos de alegria e dificuldade compartilhados.

Aos funcionários do departamento de Agroindústria, Alimentos e N Nutrição, Luis Rodrigues, Rubens Pereira, Regina Marafon e Fábio pela amizade e apoio na realização deste trabalho.

Ao Sidnei Sbizaro, à Beatriz Giongo e à Midiam Gustinelle pelo apoio na biblioteca.

A todos os participantes da análise sensorial.

Aos meus familiares pelo apoio, incentivo, amor, carinho e compreensão, principalmente de meus pais Paulo e Valdeci, milhas tias Loila e Isamara e meus padrinhos $\mathcal{N}$ eracy e Getúlio.

$\mathcal{A}$ todas as pessoas que direta ou indiretamente colaboraram para a realização deste trabalho.

E a Deus, por estar sempre comigo. 


\section{SUMÁRIO}

Página

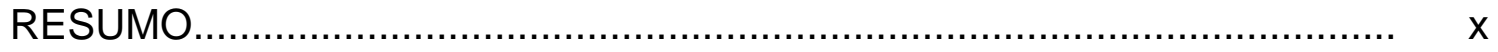

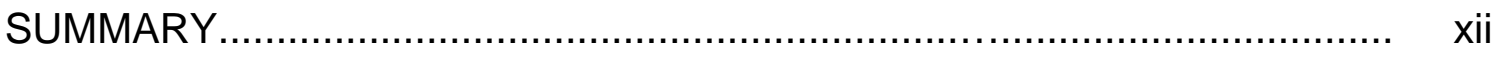

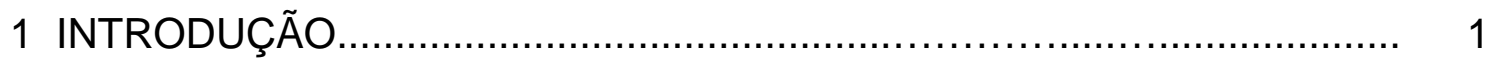

2 REVISÃO DE LITERATURA............................................................. 3

2.1 Queijo Minas Frescal................................................................. 3

2.2 Microbiologia do queijo Minas Frescal............................................. 5

2.2.1 Coliformes totais e Escherichia coli................................................ 5

2.2.2 Staphylococcus coagulase positiva............................................... 8

2.2.3 Microrganismos mesófilos aeróbios................................................ 11

2.2.4 Microrganismos psicrotróficos aeróbios......................................... 12

2.3 Atmosfera modificada..................................................................... 13

2.3.1 Atmosfera modificada em queijos................................................. 16

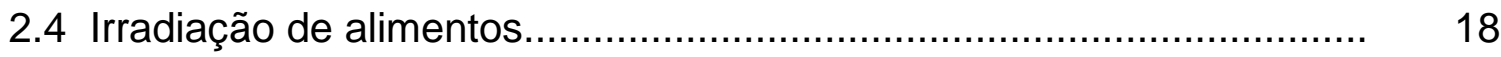

2.4.1 Irradiação em queijos................................................................ 21

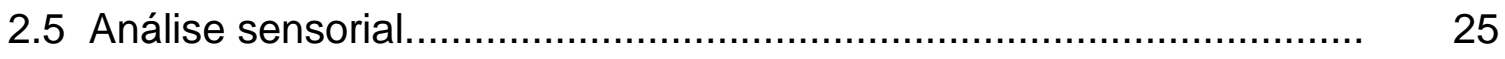

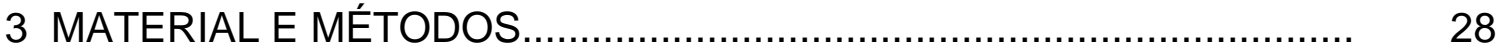

3.1 Preparação do queijo Minas Frescal sob atmosfera modificada.......... 28

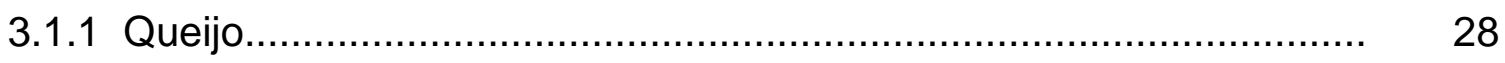

3.1.2 Fracionamento do queijo e preparação das embalagens.................. 28

3.1.3 Formação da atmosfera modificada............................................... 29

3.2 Preparação do queijo Minas Frescal sob atmosfera modificada e irradiado........................................................................ 30

3.2 .1 Queijo..................................................................... 30 
3.2.2 Fracionamento do queijo e preparação das embalagens.................. 30

3.2.3 Formação da atmosfera modificada.............................................. 31

3.2.4 Irradiação do queijo Minas Frescal sob atmosfera modificada.......... 32

3.3 Análises microbiológicas........................................................... 32

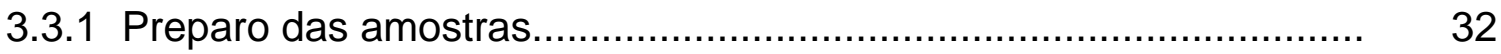

3.3.2 Staphylococcus coagulase positiva............................................ 32

3.3.3 Contagem de microrganismos mesófilos aeróbios totais................. 33

3.3.4 Contagem de microrganismos psicrotróficos aeróbios e anaeróbios

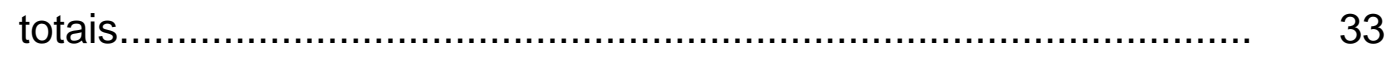

3.3.5 Contagem de coliformes totais e Escherichia coli.......................... 34

3.4 Análises físico-químicas............................................................... 34

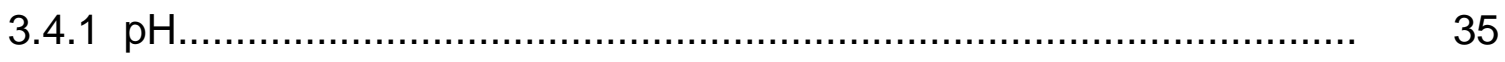

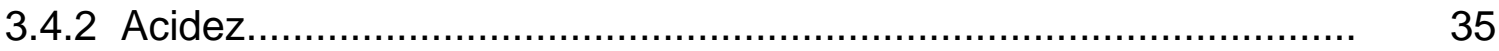

3.4.3 Extrato seco total (EST) e umidade ........................................... 35

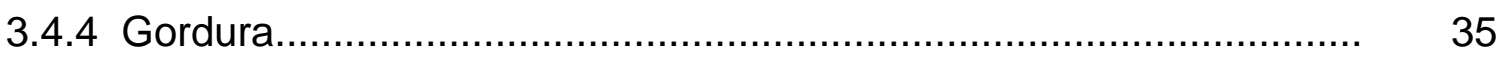

3.4.5 Gordura no extrato seco (GES) .............................................. 36

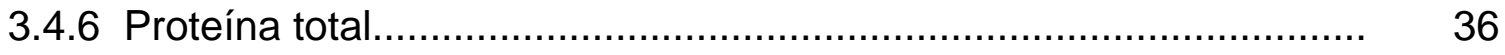

3.4.7 Resíduo mineral fixo.................................................................. 36

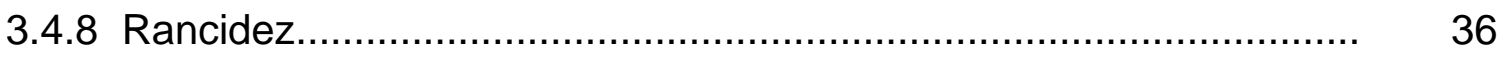

3.5 Análise de composição gasosa do espaço livre.................................. 36

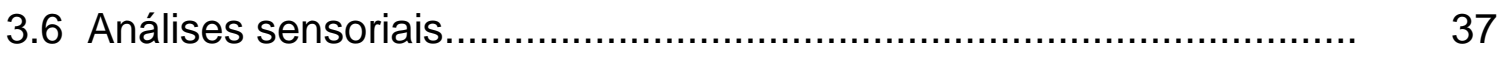

3.6.1 Análises sensoriais utilizadas para o queijo Minas Frescal sob atmosfera modificada......................................................... 37

3.6.2 Análises sensoriais utilizadas para o queijo Minas Frescal sob atmosfera modificada e irradiado................................................ $\quad 39$

3.6.2.1 Seleção de provadores............................................................ 39

3.6.2.2 Treinamento de provadores..................................................... 41

3.6.2.3 Avaliação do experimento........................................................ 44

3.6.2.4 Análise estatística................................................................... 44

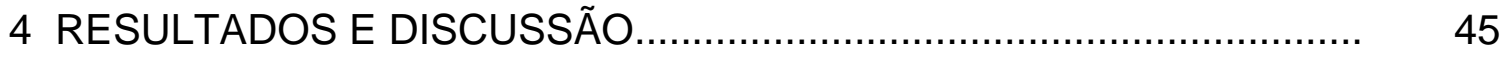


4.1 Análises microbiológicas

4.1.1 Qualidade da matéria-prima utilizada no experimento com atmosfera modificada

4.1.2 Comportamento da população bacteriana no queijo Minas Frescal sob atmosfera modificada.

4.1.2.1 Evolução da população de mesófilos aeróbios totais.................... 47

4.1.2.2 Evolução da população de psicrotróficos aeróbios totais............... 49

4.1.2.3 Evolução da população de psicrotróficos anaeróbios totais........... 52

4.1.2.4 Evolução da população de Staphylococcus coagulase positiva..... 53

4.1.2.5 Evolução da população de coliformes totais............................. 55

4.1.2.6 Evolução da população de Escherichia coli.............................. 57

4.1.3 Qualidade da matéria-prima utilizada no experimento com atmosfera modificada e irradiado.

4.1.4 Efeito da irradiação sobre a população microbiana nos queijos embalados sob ar atmosférico, ATM e Vácuo.

4.1.4.1 Contagem de mesófilos aeróbios totais.

4.1.4.2 Contagem de psicrotróficos aeróbios totais.

4.1.4.3 Contagem de psicrotróficos anaeróbios totais.

4.1.4.4 Contagem de Staphylococcus coagulase positiva.

4.1.4.5 Contagem de coliformes totais.

4.1.4.6 Contagem de Escherichia coli.

4.1.5 Comportamento da população bacteriana no queijo Minas Frescal sob atmosfera modificada e irradiado.

4.1.5.1 Evolução da população de mesófilos aeróbios totais.

4.1.5.2 Evolução da população de psicrotróficos aeróbios totais............... 71

4.1.5.3 Evolução da população de psicrotróficos anaeróbios totais........... 73

4.1.5.4 Evolução da população de Staphylococcus coagulase positiva..... 74

4.1.5.5 Evolução da população de coliformes totais............................ 76

4.1.5.6 Evolução da população de Escherichia coli............................... 78

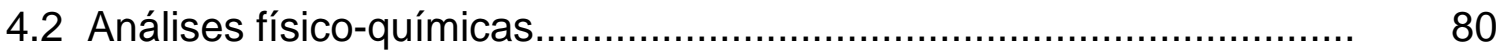


4.2.1 Resultados obtidos com o queijo Minas Frescal sob atmosfera

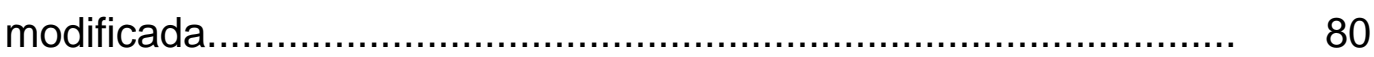

4.2.2 Resultados obtidos com o queijo Minas Frescal sob atmosfera modificada e irradiado.............................................................. 83

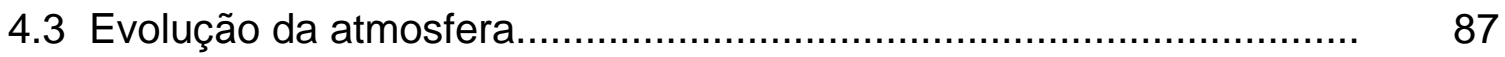

4.4 Análise sensorial.......................................................................... 90

4.4.1 Resultados obtidos com o queijo Minas Frescal sob atmosfera modificada.............................................................................. 90

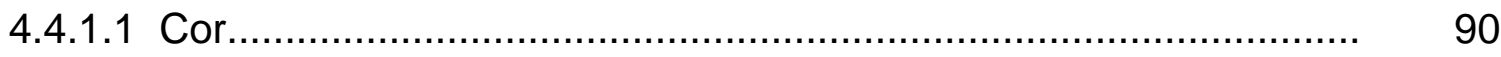

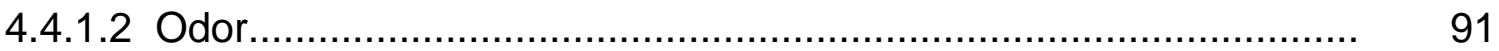

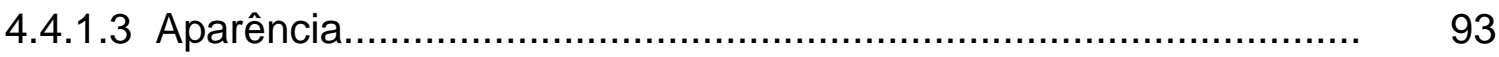

4.4.2 Resultados obtidos com o queijo Minas Frescal sob atmosfera modificada e irradiado............................................................ 96

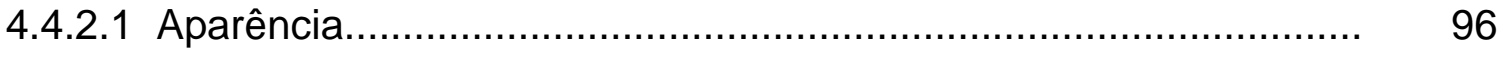

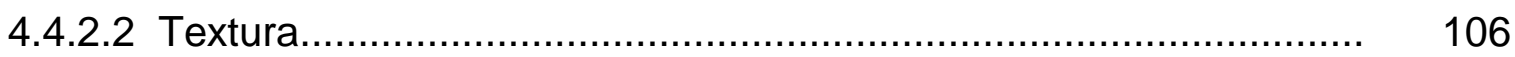

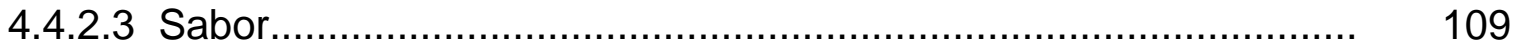

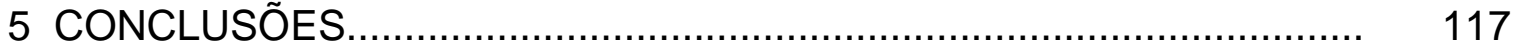

REFERÊNCIAS BIBLIOGRÁFICAS..................................................... 119 


\title{
EFEITOS DA ATMOSFERA MODIFICADA E DA IRRADIAÇÃO SOBRE AS CARACTERÍSTICAS MICROBIOLÓGICAS, FÍSICO-QUÍMICAS E SENSORIAIS DO QUEIJO MINAS FRESCAL
}

\author{
Autora: VANESSA PIRES DA ROSA \\ Orientador: Prof. Dr. ERNANI PORTO
}

\section{RESUMO}

O experimento foi dividido em duas partes, sendo que inicialmente estudou-se os queijos Minas Frescal embalados sob ar atmosférico, atmosfera modificada de $70 \% \mathrm{CO}_{2}$ e $30 \% \mathrm{~N}_{2}$ (ATM) e Vácuo e na segunda parte os queijos embalados sob os três tratamentos foram irradiados com doses de $2 \mathrm{KGy}$, sendo analisadas, nas duas partes do experimento, a evolução microbiana e as características sensoriais e físico-químicas do queijo sob os diferentes tratamentos durante o armazenamento a $4^{\circ} \mathrm{C}$. Na primeira fase do experimento verificou-se que a ATM e o Vácuo diminuíam a intensidade de crescimento da população de microrganismos mesófilos e psicrotróficos totais e reduziram a população de Staphylococcus coagulase positiva, mas não foram eficientes para o controle das populações coliformes totais e Escherichia coli, enquanto que no controle todas as populações cresceram continuamente, segundo os aspectos sensoriais de cor, odor e aparência dos queijos, mantiveram essas características durante os 40 dias de armazenamento e o controle diminuiu os 
índices de aceitabilidade progressivamente sendo rejeitado no $17^{\circ}$ dia. $\mathrm{Na}$ segunda parte do experimento observou-se que irradiação no queijo Minas frescal com 2 KGy reduziu as populações de bactérias mesófilas aeróbias, psicrotróficas aeróbias e anaeróbias, Staphylococcus coagulase positiva, coliformes totais e Escherichia coli e os tratamentos ATM e Vácuo foram muitos eficientes pois eles evitaram o crescimento destes microrganismos durante o armazenamento, enquanto que no controle a população de mesófilos e psicrotróficos aeróbios cresceu durante o armazenamento. Segundo as características sensoriais, o tratamento ATM foi o mais eficiente pois este manteve a aparência, textura e sabor por mais de 43 dias, o vácuo por 36 dias e o controle por apenas 8 dias. A utilização da irradiação com atmosfera modificada juntamente com baixas temperaturas de armazenamento aumentaram a vida útil do queijo, impedindo o desenvolvimento microbiano no produto e mantendo suas características sensoriais. 


\title{
EFFECTS OF THE MODIFIED ATMOSPHERE AND IRRADIATION ON THE MICROBIOLOGICAL, PHYSICAL-CHEMICAL AND SENSORY CHARACTERISTICS OF THE "MINAS FRESCAL" CHEESE
}

\author{
Author: VANESSA PIRES DA ROSA \\ Adviser: Prof. Dr. ERNANI PORTO
}

\section{SUMMARY}

The experiment was divided into two parts. Initially, it was studied the "Minas Frescal" cheeses packed under atmospheric air, modified atmosphere of $70 \% \mathrm{CO}_{2}$ and $30 \% \mathrm{~N}_{2}$ (ATM) and vacuum. Second the cheeses packed under these three treatments had been radiated by doses of $2 \mathrm{KGy}$. In the two parts of the experiment, it was analyzed the microbial evolution and, the sensory and physical-chemical characteristics of the cheeses under the different treatments during a $4^{\circ} \mathrm{C}$-storage. In the first phase of the experiment it was verified that the ATM and the vacuum decreased the intensity of the total population growth of aerobic mesophilic and psichorotrophs and had reduced the population of Staphylococcus positive coagulase, but they had not been efficient controlling the total coliforms and Escherichia coli, while in control all the populations had continuously grown, according to the sensory characteristics of the cheeses, color, odor and appearance. These characteristics were kept the same during the 40 days of storage, and the control decreased the acceptability levels gradually, being rejected in the $17^{\text {th }}$ day. In the second part of the experiment, it was observed that a 2KGy-irradiation over the "Minas Frescal" cheeses reduced 
the populations of aerobic mesophilic, aerobic and anaerobic psichorotrophs, Staphylococcus positive coagulase, total coliforms and Escherichia coli. The ATM and vacuum treatments were very efficient therefore they prevented the growth of these microrganisms during the storage, while in control, the aerobic mesophilic and psichrotrophs population grew during the storage. According to sensory aspects, the ATM treatment was the most efficient one, because it kept the appearance, texture and flavor for more than 43 days while the vacuum kept for 36 days and the control for only 8 days. The use of the irradiation with modified atmosphere and low temperatures of storage increased the shelflife of the cheeses, hindering the growth of the microbial populations in the product and keeping product sensory characteristics. 


\section{INTRODUÇÃo}

A elaboração de queijos constitui uma das mais importantes atividades da indústria de laticínios, sobretudo no Brasil, onde um dos tipos de maior produção e consumo é o queijo Minas Frescal, cuja produção se concentra, principalmente, em indústrias de pequeno e médio porte das regiões Sul e Sudeste (Pinto et al., 1996). Isso se deve, em parte, ao maior rendimento obtido na elaboração desses queijos, ao processamento simples que requerem e à ausência de maturação do produto final, o que possibilita um retorno rápido do investimento $\mathrm{e}$, conseqüentemente, custos menores aos consumidores (Behmer, 1984; Felício Filho, 1984 e Pinto et al., 1996).

Em muitos casos, esse produto é fabricado com deficientes práticas de higiene e com matéria-prima de má qualidade, podendo ocorrer contaminação ou recontaminação do produto por diversos microrganismos, comprometendo a sua qualidade assim como a saúde do consumidor. Além disso, é comercializado em embalagens plásticas comuns, amarradas ou fechadas com fechos metálicos, sem usar vácuo. Durante a comercialização, essa embalagem apresenta-se normalmente com um depósito de soro exsudato pelo produto. Esse dessoramento, que ocorre devido ao excesso de umidade nos queijos, além de proporcionar um aspecto pouco atraente ao produto, favorece o desenvolvimento de microrganismos contaminantes responsáveis pelo desenvolvimento de sabores e odores desagradáveis. Por essas razões, o queijo Minas Frescal apresenta, geralmente, uma vida útil muito curta, no máximo duas semanas, mesmo em temperaturas adequadas de refrigeração (Oliveira, 1986). 
O aumento da vida útil do queijo Minas Frescal pode ser possível pela modificação da atmosfera em que está envolvido. Há duas maneiras comumente usadas pela indústria alimentícia para modificar a atmosfera gasosa no interior de um produto embalado: a) aplicação de vácuo; e b) introdução de gases desejados, após evacuação e antes do fechamento da embalagem. A embalagem a vácuo consiste em envolver o produto em um filme de baixa permeabilidade ao oxigênio, com remoção do ar da embalagem e aplicação de uma selagem hermética (Smith et al., 1990). A embalagem com gás é uma extensão desse processo, envolvendo a remoção do ar da embalagem e sua substituição por gases específicos, um único gás ou uma combinação deles (Parry, 1993; Church \& Parsons, 1995).

Outro método utilizado para aumentar a vida útil desse produto é a irradiação que constitui hoje uma das formas mais modernas, seguras e eficientes para a preservação de alimentos. A irradiação reduz ou elimina a população de microrganismos presentes nos alimentos, melhorando a sua qualidade e a sua durabilidade (Wagner, 2000).

A união de múltiplas barreiras, como irradiação de alimentos com temperaturas de refrigeração em embalagens sob atmosfera modificada, atuará com mais eficiência para manter uma boa qualidade microbiológica e sensorial nos alimentos, por um período maior, quando comparados com aqueles termicamente pasteurizados ou esterilizados.

Assim, este trabalho tem como objetivo estudar o efeito da atmosfera modificada e da irradiação nas características microbiológicas, físico-químicas e sensoriais do queijo Minas Frescal e avaliar as possíveis vantagens do uso da atmosfera modificada e irradiação na conservação e extensão da vida útil do queijo Minas Frescal. 


\section{REVISÃO DE LITERATURA}

\subsection{Queijo Minas Frescal}

O queijo Minas Frescal é tradicionalmente produzido no Brasil, desde o período colonial; sua fabricação originou-se no estado de Minas Gerais, com procedimentos caseiros desenvolvidos, principalmente, na cidade do Serro (Oliveira, 1986; Behmer, 1984).

Segundo Brasil (2001), entende-se por queijo o produto fresco ou maturado que se obtém por separação parcial do soro do leite ou leite reconstituído (integral, parcial ou totalmente desnatado), ou de soros lácteos coagulados pela ação física do coalho, de enzimas específicas, de bactérias específicas, de ácidos orgânicos, isolados ou combinados, todos de qualidade apta para uso alimentar, com ou sem agregação de substâncias alimentícias e/ou especiarias e/ou condimentos, aditivos especificamente indicados, substâncias aromatizantes e matérias corantes.

De acordo com Brasil (2001), o queijo fresco obtido por coagulação enzimática do leite com coalho e/ou outras enzimas coagulantes apropriadas, complementada ou não com ação de bactérias lácteas específicas.

O processamento do queijo Minas Frescal é constituído das seguintes etapas: pasteurização do leite, coagulação, corte, dessora, enformagem, salga, embalagem e refrigeração (Vieira \& Neto, 1982).

O queijo Minas Frescal é um dos produtos mais largamente produzidos pela indústria de laticínios do País. Representou, no ano de 2000, 9,14\% da 
produção total de queijos, perdendo apenas para produção de queijo Mussarela e Prato que representaram 39,6\% e 29,57\%, respectivamente (Leite Brasil, 2003). Tem grande aceitação no mercado. Além disso, apresenta diversas vantagens sob o ponto de vista tecnológico: é um produto de fácil aceitação, apresenta elevado rendimento na fabricação e, sobretudo, não tem maturação, o que facilita grandemente o seu escoamento e distribuição no mercado (Woslfschoon-Pombo et al., 1978; Furtado \& Lourenço Neto, 1994).

Por outro lado, este queijo apresenta vários pontos críticos, durante a fabricação, que podem conduzir a alterações no produto final, dentre eles podem-se destacar: matéria-prima com alta contaminação microbiológica, recontaminação do leite pós-pasteurizado e temperatura inadequada de fabricação. Condições incorretas de manufatura e armazenagem contribuem também de forma efetiva para a má qualidade do produto (Santos et al., 1995; Mandil et al., 1982). Além disso, em geral a mão de obra é desqualificada e há deficiência de controle de higiene durante o processamento, o que pode acarretar contaminação por diversos microrganismos, comprometendo tanto sua qualidade como a segurança da saúde do consumidor (Spreer, 1991; Pereira et al., 1999 e Furtado \& Lourenço Neto, 1994). Por esse motivo, as práticas higiênicas devem ser observadas com rigor, para prevenir a contaminação ou recontaminação do produto. Além disso, por não ser maturado, é um produto perecível, devendo ser consumido rapidamente, após curta estocagem em ambiente refrigerado (Silva \& Leitão, 1980).

A bibliografia nacional revela de maneira repetitiva um quadro desfavorável da qualidade higiênica dos principais queijos consumidos no Brasil, incluindo o queijo Minas Frescal (Raimund,1992; Gomes \& Gallo, 1995; Rodrigues et al.,1995; Oliveira et al., 1998; Borelli et al., 2000; Leite Junior et al., 2000 e Silva et al. 2001). A comercialização do produto, em desacordo com os padrões de qualidade vigentes podem refletir na ocorrência de casos e surtos de enfermidades transmitidas por alimentos (ETA), o que aumenta a 
preocupação com as características microbiológicas do produto (Pelczar et al., 1981; Almeida Filho \& Nader filho, 2000).

\subsection{Microbiologia do queijo Minas Frescal}

Os microrganismos presentes no queijo Minas Frescal podem ser originários da matéria-prima de má qualidade ou por deficiências no processo de pasteurização, contaminação durante o processamento por equipamentos, utensílios e manipuladores ou durante armazenamento inadequado. Podem-se encontrar os seguintes microrganismos no queijo: Staphylococcus aureus, Bacillus cereus, Escherichia coli, Salmonella, Listeria monocytogenes, Campylobacter, Yersinia, Lactobacillus, Pseudomonas, Flavobacterium, Acinetobacter, Streptococcus, entre outros (Scott, 1991).

Os principais microrganismos ou grupo de microrganismos que têm sido sugeridos como indicadores de contaminação em queijos frescos são bactérias como coliformes, Staphylococcus e contagem total de aeróbios mesófilos e psicrotróficos (Reinbold, 1983; Carvalho, 1999).

Também estão presentes em queijos as bactérias lácticas responsáveis pela fermentação láctica, a qual influencia no sabor e aroma do produto. Fazem parte deste grupo os seguintes gêneros bacterianos: Lactobacillus, Leconostoc, Pediococcus, Streptococcus, Lactococcus, Enterococcus, Carnobacterium e Vagococcus (Pelczar et al., 1997).

\subsubsection{Coliformes Totais e Escherichia coli}

Os coliformes totais são compostos por bactérias da Família Enterobacteriaceae, capazes de fermentar lactose produzindo ácido e gás num período de $24-48$ horas a $32-37^{\circ} \mathrm{C}$. São bacilos Gram negativos, não esporulados, sendo aeróbios ou anaeróbios facultativos (Silva et al., 1997; Franco \& Landgraf, 1996). 
Fazem parte deste grupo bactérias pertencentes aos gêneros Escherichia, Klebsiella, Serratia, Hafnia e Citrobacter (Reinbold, 1983; ICMSF, 1983 e Calci et al., 1998). Destes, apenas Escherichia coli tem como habitat primário o trato intestinal do homem e animais. Os demais, além de serem encontrados nas fezes, também estão presentes em outros ambientes como vegetais e solos, onde persistem por tempo superior ao de bactérias patogênicas de origem intestinal como Salmonella e Shigella (Ribeiro et al., 1991).

As bactérias pertencentes ao gênero Escherichia são organismos largamente distribuídos na natureza. Esta foi isolada pela primeira vez em 1985 e denominada Bacillus coli e Bacterium coli (Buchanan \& Gibbons, 1994) e caracterizada em 1886 (Merchant, 1950).

Escherichia coli apresentam-se como bastonetes Gram negativos $(0,5$ por 1 a $3 \mu \mathrm{m}$ ), que podem ser móveis, dotados de flagelos peritríqueos ou imóveis, não esporulados. As bactérias crescem bem em meios de cultura artificiais e formam ácido e gás a partir da glicose e lactose. Estas bactérias apresentam antígenos somáticos $\mathrm{O}$, relacionados com polissacarídeos da membrana externa; antígenos flagelares $\mathrm{H}$ relacionados com as proteínas do flagelo, e ainda antígenos $\mathrm{K}$, relacionados com polissacarídeos moleculares (Franco \& Landgraf, 1996).

A E. coli apresenta temperatura ótima de crescimento, variando entre 35 a $40^{\circ} \mathrm{C}$, temperatura máxima de crescimento entre 44 a $46^{\circ} \mathrm{C}$. A atividade de água mínima que permite seu crescimento é de 0,95 . O pH ótimo para o seu crescimento é em torno de 6,0 a 7,0, sendo o mínimo a 4,4 e o máximo a 9,0 (ICMSF, 1998).

A presença de coliformes totais indica condições higiênicas insatisfatórias, com provável contaminação pós-processamento; deficiência nos processos de limpeza, sanificação e tratamento térmico; e multiplicação durante o processamento ou estocagem (Silva Junior et al., 2001). 
O significado da presença de E. coli em um alimento deve ser avaliado sob dois ângulos. Inicialmente, E. coli, indica uma contaminação microbiana de origem fecal, portanto está em condições sanitárias insatisfatórias. Outro aspecto a ser considerado é que diversas linhagens de $E$. coli são comprovadamente patogênicas para o homem e os animais (Silva et al., 1997; Mackey, 1980).

Com base nos fatores de virulência, manifestações clínicas e epidemiológicas, as linhagens de Escherichia coli consideradas patogênicas podem ser agrupadas nas seguintes classes: enterotoxigênica (ETEC); enteropatogênica (EPEC); enterohemorrágica (EHEC); enteroagregativa (EAggEC); enteroinvasiva (EIEC) e difusivamente adesiva (DAEC) (Franco \& Landgraf, 1996).

E. coli sorotipo O157:H7 tem sido reconhecida mundialmente como um dos microrganismos mais importantes na gênese de doenças humanas veiculadas por alimentos. A patogenecidade do microrganismo está associada a determinados fatores de virulência, destacando-se a produção de diferentes citotoxinas (Wang et al., 1996). A E. coli O157:H7 apresenta considerável resistência ao $\mathrm{pH}$ ácido, o que é fator importante para patógenos veiculados por alimentos (Lin et al., 1996). O gado bovino parece ser o principal reservatório destes microrganismos. (Wang et al., 1996; Ribeiro et al, 1999). A transmissão para humanos ocorre, principalmente, pelo consumo de alimentos contaminados, como carne crua, leite, queijo e iogurte (Ribeiro et al., 1991).

No caso de queijo, os coliformes estão relacionados com o estufamento devido à produção de gases; além disso eles, acidificam o produto, ocasionando alteração no sabor (Jay, 1994; Furtado, 1999).

O grupo coliforme é freqüentemente pesquisado em alimentos, sendo o queijo um dos principais veículos de toxinfecção alimentar, pois a presença destes microrganismos está associada às práticas de higiene e manipulação inadequadas (Raibnitz et al., 1998). 
Vários trabalhos de incidência de coliformes fecais em queijo Minas Frescal mostram uma contagem superior a $10^{2} \mathrm{UFC} / \mathrm{g}$, que é o valor máximo permitido segundo a Resolução RDC $n^{0}$ 12, de 2 de Janeiro de 2001 (Agência Nacional de Vigilância Sanitária - ANVISA, 2001). Podem ser citados os trabalhos de Colen et al. (1984); Pereira et al. (1987); Raimund (1992); Laicini (1993); Souza et al. (1993); Santos et al. (1995); Dias et al. (1995); Rodrigues et al. (1995); Carvalho et al. (1996); Oliveira et al. (1998) e Leite Junior et al. (2000).

Para prevenir a contaminação deste grupo bacteriano é necessário haver uma matéria-prima de boa qualidade, higiene durante o processamento tanto de equipamentos e utensílios quanto de manipuladores e condições adequadas de conservação (Bishop \& White, 1986). Há vários métodos para controlar essa população em queijo Minas Frescal, dentre estes podem-se destacar a refrigeração, uso de atmosferas modificadas/controladas e uso de irradiação.

\subsubsection{Staphylococcus coagulase positiva}

De acordo com o Bergey's Manual of Determinative Bacteriology (Buchanan \& Gibbons, 1994) 19 espécies fazem parte deste gênero. Destas, as seguintes apresentam interesse potencial em microbiologia de alimentos: $S$. aureus, S. hyicus, S. chromogens e S. intermedius, sendo o $S$. aureus mais importante.

Staphylococcus aureus se apresenta em forma de cocos Gram positivos não esporulados, catalase e coagulase positivos, que se dividem em mais de um plano para formar racimos tridimensionais de células, denominados "cachos de uva". S. aureus causa intoxicação provocada pela ingestão do alimento que contém a toxina pré-formada. Portanto, o agente causal não é a bactéria, mas as várias toxinas $\left(A, B, C_{1}, C_{2}, C_{3}, D, E\right)$ produzidas por estas bactérias, conhecidas como enterotoxinas (Chordash \& Potter, 1976; Bourgeois et al., 1994). 
São bactérias mesófilas apresentando temperatura para crescimento entre 7 e $48^{\circ} \mathrm{C}$, sendo $37^{\circ}$ a temperatura ótima. Para a produção de toxina é de 10 a $48^{\circ} \mathrm{C}$, sendo 40 a $45^{\circ}$ a faixa ótima. $\mathrm{O} \mathrm{pH}$ para crescimento é de 4 a 10 , sendo o ótimo 6 a 7 e para a produção de toxina 4,5 a 9,6, sendo o ótimo de 7 a 8. A atividade de água para crescimento é de 0,83 a 0,99, sendo o ótimo 0,98 e para a produção de toxina, de 0,87 a 0,99 , sendo ótimo também a 0,98 . São tolerantes a concentrações de 10 a $20 \%$ de $\mathrm{NaCl}$ e a nitratos, o que torna alimentos curados veículos potenciais para a contaminação com Staphylococcus (Speck, 1992; Holt et al., 1994 e ICMFS, 1998).

A importância de outras espécies dentro desse gênero tem aumentado, de modo que se leva em consideração a detecção também da presença de Staphylococcus coagulase positiva como S. hyicus e S. intermedius, em alimentos, pois estes também são capazes de produzir enterotoxinas que prejudicam o ser humano (Jay, 1994; Bourgeois et al., 1994 e Germano \& Germano, 2001).

Os estafilococos, sobretudo S. aureus, a partir do homem e animais de sangue quente, dispõem de fácil disseminação até os alimentos, distribuindo-se também no ambiente, ar, poeira e águas de esgoto, e passam a constituir problemas quando atingem locais específicos nos laticínios e outras indústrias de alimentos (Bryan, 1974; Jay, 1994; Eifert et al., 1996; Hobbs \& Roberts, 1997; ICMSF, 1998; Pereira et al., 1996). Os portadores nasais e os manipuladores de alimentos com mãos e braços que apresentem feridas infectadas com S. aureus são importantes fontes de contaminação no alimento. Além do homem, a maioria dos animais também é portadora ou apresenta-se contaminada pela bactéria. Exemplo típico é a mastite estafilocócica do gado leiteiro. Caso o leite infectado seja consumido ou utilizado no preparo de queijos, haverá chances de ocorrer intoxicação (Smith et al, 1983; Carvalho, 1999; Pereira et al., 1999; Trabulsi et al., 1999 e Hatakka et al., 2000). 
Uma vez ingerido o alimento, o período de incubação do surto é geralmente de 30 minutos a oito horas, sendo a média de duas a quatro horas. Os principais sintomas são náuseas, vômitos cãibras abdominais, diarréia, sudorese, dores de cabeça, calafrio, entre outros (Tibana et al., 1987; Pereira et al., 1996).

Entre os alimentos envolvidos, pode-se citar o leite e seus derivados, como queijos (Bryan, 1988). De um modo geral, todos os alimentos que requerem considerável manipulação durante o seu preparo e cuja temperatura de refrigeração é inadequada, são passíveis de causar intoxicação (Hayes, 1993; Bourgeois et al., 1994 e Germano \& Germano, 2001). O microrganismo não é bom competidor com outras bactérias e por isso, raramente causa doenças alimentares em alimentos crus. O organismo é inativado rapidamente pelo calor, mas é resistente à secagem e é tolerante a altas concentrações de sais (Hurst \& Hughes, 1983).

Vários trabalhos de incidência de $S$. aureus em queijo Minas Frescal mostram uma contagem superior a $10^{2} \mathrm{UFC} / \mathrm{g}$, que é o valor máximo permitido segundo a Resolução RDC $n^{0}$ 12, de 2 de Janeiro de 2001. Podem ser citados os trabalhos Raimund (1992); Rodrigues et al. (1995); Carmo et al. (1995); Gomes \& Gallo (1995); Santos et al. (1995); Borelli et al. (2000); Leite Junior et al. (2000) e Silva et al. (2001).

A manipulação do alimento pelo homem, um dos reservatórios desta bactéria, é causa provável de contaminação. O aquecimento do alimento logo após a sua manipulação destrói o microrganismo, ajudando a prevenir a intoxicação. O resfriamento rápido de toda a massa alimentícia é uma das medidas para a prevenção e controle desta intoxicação (Tatini et al., 1976).

Para a produção de enterotoxinas suficiente para causar surto, julga-se uma população no alimento entre $10^{5}$ e $10^{6} \mathrm{UFC} / \mathrm{g}$ de $S$. aureus. Assim, controlando fatores que afetam o crescimento de $S$. aureus, a produção de toxina também está sendo controlada e, conseqüentemente, os surtos de intoxicação ( Scheusner \& Harmon, 1973; Pereira et al., 1999). 


\subsubsection{Microrganismos mesófilos aeróbios}

Este tipo de contagem é amplamente utilizado em microbiologia de alimentos, e através dela pode-se determinar a qualidade bacteriológica do alimento analisado. A contagem de aeróbios mesófilos funciona como um indicador de qualidade de alimentos (Reinbold, 1983). A maioria das bactérias patogênicas são mesófilas, assim analisar um alimento e encontrar um elevado número de bactérias deste grupo é sinal de que podem existir bactérias patogênicas no produto (Carvalho, 1999). A contagem deste tipo de bactérias inclui os microrganismos que crescem em aerobiose e temperaturas de incubação entre 15 e $45^{\circ} \mathrm{C}$, com uma temperatura média de $35^{\circ} \mathrm{C}$ (Silva Junior, 2001).

A contagem elevada deste grupo de bactérias nos alimentos perecíveis também é indicativo do uso de matéria-prima contaminada ou processamento insatisfatório, sob o ponto de vista sanitário. Podendo, também, indicar abuso durante o armazenamento em relação ao binômio tempo/temperatura (Franco \& Landrag, 1996).

A deterioração de alimentos pode ser causada pelo crescimento microbiano que levaria as alterações sensoriais. Neste caso, números elevados são esperados e variam com o tipo de alimento e microrganismo presente. A maioria dos alimentos apresenta, quando essas alterações são detectáveis, populações superiores a $10^{6} \mathrm{UFC} / \mathrm{g}$ do alimento. Entretanto, há aqueles em que são necessários $10^{7}$ ou até mesmo $10^{8} \mathrm{UFC} / \mathrm{g}$. Os alimentos fermentados apresentam população microbiana de, aproximadamente, $10^{8} \mathrm{UFC} / \mathrm{g}$ sem, no entanto, serem considerados deteriorados (Carvalho, 1999). 


\subsubsection{Microrganismos psicrotróficos aeróbios}

A contagem total de microrganismos aeróbios psicrotróficos avaliam 0 grau de deterioração de alimentos refrigerados (Reinbold, 1983).

Dentre os gêneros presentes neste grupo estão Pseudomonas e Listeria. A espécie Psedomonas fluorescens, além de alterar os alimentos com a produção de enzimas termorresistentes estimula o crescimento de patógenos como Listeria monocytogenes e E. coli O157: H7 (Farrag \& Marth, 1989; Quinto et al., 1997 e Santos et al., 1999). A presença de um grande número de espécies de microrganismos psicrotróficos pode estar relacionado com ocorrência de toxinfecções alimentares humanas ou com deterioração e perda de qualidade organoléptica dos alimentos (Santos et al., 1999).

A introdução da armazenagem refrigerada do leite cru, antes de seu processamento, sanou o problema de alterações de sabor e desenvolvimento de acidez neste produto devido à ação das bactérias mesofílicas, mas trouxe à tona outro sério problema: a seleção de microrganismos psicrotróficos (Furtado, 1999). Algumas dessas bactérias psicrotróficas são sensíveis aos tratamentos térmicos utilizados, outras não (Santos et al., 1999). Porém, independente da bactéria ser sensível ou não aos tratamentos térmicos, muitas delas produzem enzimas lipolíticas e proteolíticas durante o seu crescimento na armazenagem refrigerada (Adams et al.,1974; Anderson et al., 1979 e Adams et al.,1981). Essas enzimas são termoressistentes e atuam no leite causando efeitos de geleificação e sabor indesejável do leite U.H.T. Também podem ocasionar diminuição do rendimento na fabricação do queijo e o desenvolvimento de sabor amargo e de ranço no produto acabado e alteram também a textura do produto, comprometendo, deste modo, a sua qualidade (Furtado, 1999; Santos et al., 1999).

Em relação à quantidade de bactérias psicrotróficas necessárias em um determinado produto, para que possa haver alterações de natureza proteolítica 
e/ou lipolítica, cita-se que os problemas aparecem quando a contagem destes microrganismos atinge $10^{7} \mathrm{UFC} / g$ (Santos et al., 1999).

Além dos microrganismos psicrotróficos que causam alterações no leite e em queijos, espécies de psicrotróficos potencialmente patogênicos (Yersinia enterocolítica e Listeria spp.) podem também estar presentes nestes produtos (Ahmed et al.,1983; Santos et al., 1999). As fontes de contaminação do leite com estas bactérias são muito variadas e incluem solo, água, forragem, alimentação do gado, a superfície externa do úbere, infecções do úbere, pessoal responsável pela ordenha, toda a linha de utensílios e equipamentos mal higienizados, transporte e processamento no laticínio (Germano \& Germano, 2001).

Para controlar estes microrganismos em queijos, deve haver boas práticas de higiene durante todo o processamento do produto. E, após, pode-se utilizar gases como $\mathrm{CO}_{2}$ que impedem o desenvolvimento deles e também adição de bactérias lácticas, que podem produzir peróxido de hidrogênio e bacteriocinas (Bourgeois et al., 1994 ).

\subsection{Atmosfera Modificada}

O processo de atmosfera modificada (ATM) começa a ganhar efetiva aplicação na conservação de alimentos em 1940. Em 1970, com os trabalhos de Kader em hortifrutículos deram significativo impulso na utilização desse processo. Em 1980, Brecht discute conceitos associados com o uso de atmosfera modificada e refrigeração, e, com isto, o respectivo efeito sinérgico resultante da interação destes dois processos sobre produtos alimentícios.

A atmosfera modificada, além de ser vista como um processo integrado alimento/gás/embalagem, ganha aplicação a partir do momento em que passa a ser vista como um processo multidisciplinar, que utiliza princípios das ciências química, física e microbiológica dos alimentos. Esse processo tem sido aplicado com considerado sucesso na Europa, desde a metade do século, e nos Estados Unidos vem ganhando espaço desde 1980 (Souza et al., 2001). 
A idéia de modificar a atmosfera ao redor de um produto alimentício, com o fim de aumentar sua vida útil, se transformou em tecnologia aplicada comercialmente na preservação de carnes, produtos lácteos, aves, pescado, produtos de confeitaria, frutas e hortaliças. A substituição do ar atmosférico por uma mistura otimizada de $\mathrm{CO}_{2}, \mathrm{~N}_{2}$ e $\mathrm{O}_{2}$ pode propiciar um aumento de vida útil, evitando a degradação de alimentos, pois estas misturas inibem o crescimento microbiano, evitam o ranço proveniente de enzimas bacterianas e oxidação e inibem a respiração de tecidos. (King \& Nagel, 1975; Sarantópoulos \& Oliveira, 1990 e Sarantópoulos \& Soler,1994).

A escolha da mistura gasosa usada é influenciada pela microbiota capaz de crescer no produto, pela sensibilidade do produto ao $\mathrm{O}_{2}$ e $\mathrm{CO}_{2}$, e estabilização do pigmento requerido. Os gases normalmente usados em embalagens com atmosfera modificada são aqueles encontrados na atmosfera: $\mathrm{O}_{2}, \mathrm{~N}_{2}$ e $\mathrm{CO}_{2}$. Para queijos de massa mole são recomendados percentuais maiores de $60 \%$ de $\mathrm{CO}_{2}$; para queijos semi-duros do tipo Prato, Edam, Gouda, Cheddar e filados como Mussarela e Provolone são utilizados percentuais maiores que $80 \%$ de $\mathrm{CO}_{2}$. $\mathrm{O}$ uso de atmosfera modificada em queijos fatiados do tipo Mussarela e Provolone, além de aumentar a vida útil, evita a compactação das fatias (Parry, 1993; Church \& Parsons, 1995).

O nitrogênio é um gás quimicamente inerte, com baixa solubilidade tanto em meio aquoso como lipídico. $\mathrm{O} \mathrm{N}_{2}$ é usado para substituir $0 \mathrm{O}_{2}$, e assim retardar a rancidez oxidativa e inibir o crescimento de microrganismos aeróbios. Devido à sua baixa solubilidade e menor permeabilidade através da embalagem em relação $\mathrm{ao}_{2}$ e $\mathrm{CO}_{2}$, é usado como um gás de enchimento para prevenir o colapso da embalagem, que pode ser um problema em atmosferas contendo altas concentrações de $\mathrm{CO}_{2}$ (Day, 1992; Church, 1993).

$\mathrm{O} \mathrm{CO}_{2}$ é solúvel tanto em meio aquoso como lipídico e é principalmente responsável pelo efeito bacteriostático e fungistático. A ação do $\mathrm{CO}_{2}$ sobre a microbiota tem sido atribuída à redução de $\mathrm{pH}$, devido à dissolução do $\mathrm{CO}_{2}$ no meio, às alterações da permeabilidade celular bacteriana e à inibição 
enzimática, resultando no prolongamento da fase de adaptação e o aumento do tempo de geração dos microrganismos, o que resulta em uma velocidade de crescimento diminuída, além de uma mudança na microflora, levando à predominância de microrganismos de menor potencial de deterioração (King \& Nagel,1975; Church, 1993; Sarantópoulos \& Soler,1994 e Brody, 1993). O CO CO $_{2}$ provoca a inibição do crescimento de bolores e bactérias psicrotróficas Gram negativas, entre elas, Pseudomonas, Acinetobacter e Moraxella, que são importantes deteriorantes de alimentos refrigerados. As bactérias lácticas, por sua vez, são estimuladas na presença de $\mathrm{CO}_{2}$ (Brody, 1993).

No entanto, a concentração de $\mathrm{CO}_{2}$ nas embalagens não apenas afeta os microrganismos, mas também pode causar alterações na cor e no sabor dos produtos. Além disso, atmosferas com altas concentrações de $\mathrm{CO}_{2}$ podem acarretar o colapso da embalagem, pois $0 \mathrm{CO}_{2}$ permeia $\mathrm{o}$ material de embalagem mais rapidamente do que o $\mathrm{O}_{2}$ e $\mathrm{N}_{2}$ e se dissolve na água e na gordura do alimento (Sarantópoulos, 1991).

Para a maioria dos alimentos, as embalagens devem conter o mínimo possível de oxigênio, com o objetivo de retardar o crescimento microbiano aeróbio e reduzir o grau de oxidação. Há, entretanto, exceções, como no caso da carne vermelha, na qual o oxigênio ajuda a preservar a forma oxigenada da mioglobina, responsável pela cor vermelha deste alimento, e no caso das frutas e legumes, torna-se necessário para garantir o processo respiratório (Godoy, 1995).

Para se obter um eficiente processo de atmosfera modificada, é necessário o monitoramento de alguns parâmetros, tais como: análise da composição gasosa no interior da embalagem, análises físico-químicas e microbiológicas e avaliação sensorial durante a vida útil do produto (Souza et al., 2001). 


\subsubsection{Atmosfera Modificada em queijos}

A vida útil e qualidade de queijos podem ser aumentadas pela utilização da atmosfera modificada, associada com refrigeração. Isso já tem sido demonstrado em diversos trabalhos encontrados na literatura.

Fandos et al (2000) estudaram queijos de leite de cabra embalados sob diferentes atmosferas (vácuo, misturas de $\mathrm{CO}_{2}$ e $\mathrm{N}_{2}$, ar atmosférico) a $4^{\circ} \mathrm{C}$, verificando que o controle, após sete dias, ficou inaceitável sensorialmente. Os queijos embalados com $50 \% \mathrm{CO}_{2}$ e $50 \% \mathrm{~N}_{2}$ e $60 \% \mathrm{CO}_{2}$ e $40 \% \mathrm{~N}_{2}$ foram os mais efetivos para o aumento da vida útil do produto, mantendo as propriedades sensoriais, estabilizando a população de mesófilos aeróbios, psicrotróficos aeróbios e coliformes.

Eliot et al (1998) estudaram a microbiologia do queijo Mussarela embalado sob 8 diferentes atmosferas modificadas (ar, vácuo e mistura de gás carbônico/nitrogênio) a $10^{\circ} \mathrm{C}$ durante oito semanas e verificaram que, em atmosferas com 50\%,75\% e $100 \%$ de $\mathrm{CO}_{2}$, houve estabilização da população de mesófilos aeróbios, de Staphylococcus e de mofos e leveduras.

Alves et al (1996) estudaram a vida útil de queijo Mussarela embalado sob três diferentes atmosferas $\left(100 \% \mathrm{CO}_{2}, 100 \% \mathrm{~N}_{2}\right.$ e $\left.50 \% \mathrm{CO}_{2} / 50 \% \mathrm{~N}_{2}\right)$. O tratamento com $100 \%$ de $\mathrm{N}_{2}$ foi satisfatório, segundo os aspectos microbiológicos e sensoriais, até 16 dias de estocagem e os demais foram 63 dias para $100 \% \mathrm{CO}_{2}$ e 45 dias para $50 \% \mathrm{CO}_{2} / 50 \% \mathrm{~N}_{2}$. O desenvolvimento de bactérias psicrotróficas aeróbias, mofos e leveduras foi inibido pelas atmosferas que continham $\mathrm{CO}_{2}$.

Sarantópoulos et al. (1993) avaliaram queijo Mussarela de leite de búfala, sob atmosfera modificada $\left(50 \% \mathrm{CO}_{2} / 50 \% \mathrm{~N}_{2}\right)$, vácuo parcial e ar atmosférico a $7^{\circ} \mathrm{C}$. Foi verificada uma redução das populações de bactérias aeróbias e dos fungos e leveduras com o uso de atmosfera modificada, sendo que a vida útil foi de 24 dias, segundo análise sensorial. O crescimento microbiano do produto 
sob vácuo parcial foi similar ao do produto sob ar atmosférico, o que limitou a vida útil do queijo em 11 e 10 dias, respectivamente.

Sarantópoulos et al. (1995) estudaram queijo parmesão ralado sob atmosfera com alta concentração de $\mathrm{CO}_{2}\left(1,5\right.$ litros $\mathrm{CO}_{2} / \mathrm{Kg}$ produto) a $25^{\circ} \mathrm{C}$. Não houve alterações físico-químicas no produto durante 124 dias de estocagem, sendo que após esse período, as contagens de mesófilos e de bolores e leveduras foram de $4,2 \times 10^{5}$ e 5,1 × $10^{6} \mathrm{UFC} / \mathrm{g}$, respectivamente. $\mathrm{O}$ produto teve uma vida útil de 98 dias, limitada pelas alterações de sabor, cor e aparência.

Maniar et al. (1994) também avaliaram queijo Cottage sob diversas atmosferas (100\% CO $\mathrm{CO}_{2}, 100 \% \mathrm{~N}_{2}$ e $\left.75 \% \mathrm{CO}_{2} / 25 \% \mathrm{~N}_{2}\right)$, sendo a atmosfera com $100 \% \mathrm{CO}_{2}$ a que melhor preservou as características sensoriais do queijo por 28 dias a $4^{\circ} \mathrm{C}$. As contagens de microrganismos psicrotróficos e bactérias lácticas permaneceram sem alterações no produto sob as diversas atmosferas modificas, mas aumentaram em torno de um ciclo nas amostras sob ar atmosférico durante a estocagem.

Moir et al (1993) inocularam Psedomonas fluorescens, Pseudomonas putida e Listeria monocytogenes em queijo Cottage acondicionado em potes de PS (poliestireno), em que a concentração de $\mathrm{CO}_{2}$ no espaço livre foi de $40 \%$ estocados a $5^{\circ}$ e $15^{\circ} \mathrm{C}$. Foi observado aumento na duração da fase de latência e redução na velocidade de crescimento da Pseudomonas, sendo a inibição maior no produto a $5^{\circ} \mathrm{C}$. A população de Listeria monocytogenes manteve-se estável.

Chen \& Hotchkiss $(1991,1993)$ inocularam uma população mista de $10^{3}$ UFC/g de três bactérias deterioradoras Gram negativas (Pseudomonas fluorescens, Pseudomonas aeroginosa e Pseudomonas marginata) em queijo Cottage, que foi posteriormente, acondicionado em potes de vidro contendo tampa metálica, com atmosfera de $35-40 \%$ de $\mathrm{CO}_{2}$. Verificaram que a atmosfera inibia o crescimento dessas bactérias no queijo. Posteriormente, esses mesmos autores inocularam linhagens de Listeria monocytogenes e 
Clostridium sporogenes em queijo Cottage acondicionado em tubos de PS com atmosfera de $35 \%$ de $\mathrm{CO}_{2}$ e no controle sob ar atmosférico. Os produtos foram estocados a $4^{\circ}$ e a $7^{\circ} \mathrm{C}$. Observou-se crescimento de Listeria no controle de $10^{4}$ para $10^{7} \mathrm{UFC} / \mathrm{g}$ após 28 dias a $4^{\circ} \mathrm{C}$ e 7 dias a $7^{\circ} \mathrm{C}$. As contagens de Clostridium sporogenes a 4 e $7^{\circ} \mathrm{C}$ e Listeria monocytogenes a $4^{\circ} \mathrm{C}$ tiveram uma redução no queijo em atmosfera de $\mathrm{CO}_{2}$, durante 63 dias de armazenamento.

Kosikowski \& Brown (1973) injetaram $\mathrm{CO}_{2}$ e $\mathrm{N}_{2}$ em potes de PVC contendo queijo tipo Cottage e selaram com tampa de alumínio. Após, verificaram que o produto continha melhor sabor, odor e textura após 45 dias a $4^{\circ} \mathrm{C}$ nas duas atmosferas modificadas, em relação ao controle. Depois desse período, ocorreram alterações sensoriais devido ao desenvolvimento de um sabor azedo, fermentado e alterações na textura.

\subsection{Irradiação de alimentos}

A irradiação como um processo para a conservação de alimentos tem sido muito estudado, e o seu emprego na conservação de alimentos tem passado da fase experimental à escala comercial em alguns países.

Alimentos irradiados são alimentos que foram tratados por um determinado tipo de radiação, em condições de segurança controladas, para a obtenção de alguns efeitos, tais como inibir bactérias, além de manter a qualidade do alimento por mais tempo.

A irradiação de alimentos é um tratamento que consiste em submeter os alimentos já embalados, ou a granel, a uma dose controlada de radiação ionizante, por um tempo prefixado com objetivos bem determinados. O processo não altera a radioatividade normal dos alimentos. Poderão ser utilizadas, nos alimentos as irradiações ionizantes, cuja energia seja inferior ao limiar das reações nucleares que poderiam induzir radioatividade no material irradiado. A irradiação pode impedir a divisão das células vivas, tais como 
bactérias e células de organismos superiores, ao alterar suas estruturas moleculares (Diehl, 1996).

Nos processos industriais por irradiação, é fundamental que se conheça a quantidade de energia absorvida pelo material, quando ele é exposto à radiação ionizante. A dose absorvida, ou simplesmente a dose, é a quantidade de energia absorvida. A unidade que mede a dose absorvida é o Gray (Gy), e 1 Gray = 1 Joule/Kg, cuja equivalência com rad (unidade usada anteriormente) é: $100 \mathrm{rad}=1 \mathrm{~Gy}$. A taxa de dose é a energia absorvida por unidade de tempo, assim, os irradiadores gama diferem dos aceleradores por possuírem uma baixa taxa de dose, levando mais tempo de irradiação, enquanto os aceleradores, com sua alta taxa de dose, podem ser muito mais rápidos (Diehl, 1996).

Segundo as doses de radiação aplicada pode-se distinguir em três processos: radapertização, ou esterilização comercial, que é a aplicação de doses de radiação suficientes para eliminar todos os microrganismos vivos de forma que não possam ser detectados por nenhum método microbiológico, usase com doses elevadas (10 a 70 kGy); a radicidação ou radiopasteurização, que é um processo de pasteurização que elimina totalmente apenas os microrganismos patogênicos, usando doses intermediárias (de 1 a 10 kGy). Já a radurização é a aplicação de doses ionizantes que não alteram o produto, mas reduzem sensivelmente sua carga microbiana, usando doses baixas (em média de 0,5 a 1 KGy) (Jay, 1994; Franco \& Landgraf, 1996).

As radiações ionizantes são assim chamadas porque a energia emitida é suficiente para desalojar os elétrons dos átomos e moléculas, e assim convertelos em partículas carregadas eletricamente. Radiações ionizantes provenientes de raios gama, raios $-X$ e procedentes de aceleradores de elétrons dos átomos e moléculas são utilizados industrialmente no tratamento de diversos tipos de materiais (Jay, 1994).

Só poderão ser utilizadas nos alimentos as radiações ionizantes, cuja energia seja inferior ao limiar das reações moleculares, o que poderia induzir 
radioatividade no material irradiado. Por essa razão, somente cinco fontes são permitidas: ${ }^{60} \mathrm{Co},{ }^{137} \mathrm{Cs}$, Raios - $\mathrm{X}$, Raios $\mathrm{X}$ com fótons de energia não superiores a $5 \mathrm{Mev}$ (Mega elétron volt) e feixes de elétrons acelerados com energia máxima de $10 \mathrm{Mev}$. Todas essas fontes produzem radiação com níveis de energia abaixo da necessária para induzir radioativiadade (WHO, 1994). O nível de energia produzido pelo ${ }^{60} \mathrm{Co}$ e ${ }^{137} \mathrm{Cs}$ (Diehl, 1996) não é suficientemente alto para causar radioatividade. No processo de radiação o produto munca entra em contanto com a fonte de radiação (WHO, 1994).

As vantagens de cobalto-60 como fonte de radiação são: alto poder de penetração e boa uniformidade de dose; estão comercialmente disponíveis e com baixo risco ambiental (cobalto-60 decai para formar níquel não radiativo). Como desvantagem apresenta meia-vida de 5,3 anos, e por isso $12 \%$ da fonte deve ser reposta anualmente para manter o potencial original (Jarret, 1987).

Em contraste aos isótopos como fonte de radiação gama, as radiações de feixes de elétrons acelerados e raios-X são produzidas eletricamente, resultando em um considerável consumo de energia. A principal vantagem é que são máquinas que se ligam e desligam conforme a necessidade, não precisam de reposição como cobalto-60, mas seu poder de penetração é muito pequeno. A principal diferença entre elétrons acelerados e Raio-x é que este último tem maior poder de aceleração (WHO, 1994).

No Brasil, a legislação de alimentos irradiados foi revisada e atualizada pela resolução RDC n. 21 de janeiro de 2001 da Diretoria Colegiada da Agência Nacional de Vigilância Sanitária, publicada no D.O.U. de 29 de janeiro de 2001. Trata-se de um "Regulamento técnico para irradiação de alimentos". Segundo a RDC n.21 de janeiro de 2001 fica liberada a irradiação de qualquer tipo de alimento, observadas as seguintes condições: a dose mínima absorvida deve ser suficiente para alcançar a finalidade pretendida; a dose mínima absorvida deve ser inferior àquela que comprometeria as propriedades funcionais e ou os atributos sensoriais do alimento. As fontes de radiações permitidas são aquelas autorizadas pela Comissão de Energia Nuclear (CNEN) quais sejam: Cobalto 
60 e Césio 137, Raios X gerados por máquinas que trabalham com energia até $5 \mathrm{MeV}$ e elétrons acelerados gerados por máquinas que trabalham com energias de até $10 \mathrm{Mev}$.

A irradiação pode ser utilizada juntamente com outros métodos de conservação de alimentos como refrigeração, tratamento térmico, cura e adição de substâncias químicas, a fim de prolongar, consideravelmente, a vida útil de alguns alimentos durante o período de armazenamento, refrigerados ou não, sendo necessário um envase perfeito que não permita uma nova contaminação, uma vez que o alimento estará estéril (FAO, 1996).

Um tratamento com radiações ionizantes aplicado a um alimento a fim de conservá-lo, deve apresentar eficácia em destruir todos os microrganismos causadores de alterações e patógenos, bem como atuar reduzindo o número de microrganismos viáveis em geral, com melhora na conservação do mesmo. Todavia, a dose necessária para conseguir um objetivo determinado, depende não somente do tipo de microrganismo, como também, do número de microrganismos presentes no alimento, antes da irradiação e do número de microrganismos viáveis toleráveis ao tratamento, ou seja, quanto maior o número de microrganismos presentes no alimento antes da irradiação, maior será a dose a ser empregada (FAO, 1966).

\subsubsection{Irradiação em queijos}

A tecnologia de produtos lácteos desempenha importante papel na indústria de alimentos. No leite, a dose máxima para não ocorrer efeitos indesejáveis (alteração de cor e sabor) é por volta de 0,5 KGy. Para a preservação de queijo é possível utilizar-se uma dose de até 2,0 KGy sem o aparecimento de sabores estranhos.

Gurgel (2000) inoculou S. aureus ( $10^{6} \mathrm{UFC} / \mathrm{mL}$ ) em queijo Minas Frescal irradiado com doses de 0 (controle); 1; 2; 3 e 4 KGy armazenados sob refrigeração $\left(5^{\circ} \mathrm{C}\right)$. As amostras foram analisadas nos períodos de 1,7 e 14 
dias, concluindo que doses entre 2 e 3 são indicadas para a destruição do S. aureus, não interferindo nas propriedades físico-químicas e sensoriais do produto.

Lalaguma (2003) estudou os efeitos sobre as propriedades sensoriais de baixas doses (1-5KGy) de radiação em queijo Palmita, um tipo de queijo branco, popular na Venezuela. As amostras foram analisadas imediatamente após a irradiação e após 21 dias do armazenamento a $12^{\circ} \mathrm{C}$. Nenhuma propriedade sensorial desagradável foi desenvolvida após a irradiação. Após 21 dias do armazenamento, as amostras não irradiadas foram rejeitadas sensorialmente, enquanto que as amostras irradiadas mantiveram o frescor do produto.

No trabalho realizado por Ewais et al (1990), com queijo Roquefort irradiado com 2,5 KGy em fonte de cobalto-60, durante as 8 semanas de maturação a $9^{\circ} \mathrm{C}$ e $90 \%$ UR, verificaram que a contagem total de bactérias diminui do começo ao fim da maturação. O efeito da irradiação diminui os índices de proteólise e lipólise bacteriana durante a maturação; já para a contagem de mofos e leveduras houve um aumento desta população. A irradiação reduziu a umidade e o conteúdo de gordura e aumentou a porcentagem de sal e $\mathrm{pH}$ do queijo.

Odegov et al (1974) verificaram o efeito da radiação gama com doses de 0,06 Kgray a 49,68 KGy sobre as características bacteriológicas e organolépticas do queijo Rossiiski durante a maturação. Os resultados mostraram que doses maiores que $10 \mathrm{KGy}$ esterilizaram o produto. Os queijos irradiados com doses maiores que 0,5 KGy, após 70 dias, apresentaram sabor estranho, e aqueles com doses maiores que 2,0 KGy, apresentaram sabor amargo e azedo e alteração na consistência.

Em trabalho realizado sobre as características microbiológicas e sensoriais com queijos Cammembert, Cottage e Cottage de soro irradiados com baixas doses, com 0,75 KGy foi observado que houve diminuição da população microbiana em 96\%, 99\% e 50\% da população microbiana, respectivamente. 
Nos queijos Cottage, as mudanças de sabor começaram a ser notadas a partir de 0,75 KGy e tornaram-se mais intensas com o aumento da dose de radiação. Com 0,75 KGy o sabor foi descrito como amargo, cozido e estranho. Com 2,0 KGy, um pronunciado sabor de queimado foi detectado. Para os queijos Cottage de soro, irradiados com dose de 0,30 KGy, já foi notada mudança no sabor. O sabor descrito após doses maiores (1,20 e 2,00 KGy) foi de estragado e queimado e para 0, $75 \mathrm{KGy}$ como adocicado, quando comparado com 0,30 KGy e controle. No queijo Cammembert, as mudanças foram detectadas com 0,30 KGy e tornaram-se mais pronunciadas com o aumento da dose. O sabor foi descrito como queimado ou mofado (Jones \& Jelen, 1988).

Bougle \& Stahl (1994a) verificaram que queijos Cammembert fabricados com leite cru e irradiados com dose de 2,6 KGy não sofreram alterações nas propriedades organolépticas.

Bougle \& Sthal (1994b) estudaram L. monocytogens inoculada em queijos Cammembert irradiados. A dose de 2,6 kGy não alterou as propriedades sensoriais do Cammembert, permitido uma destruição completa da população de $10^{4} \mathrm{UFC} / g$ de L. monocytogenes. Quando $10^{5} \mathrm{UFC} / \mathrm{g}$ foram inoculados no queijo, alguns eram viáveis após a irradiação e armazenamento de 45 dias a $12^{\circ} \mathrm{C}$; e as bactérias que sobreviveram eram incapazes de multiplicar-se no produto.

Um estudo foi realizado com queijo Kaseri (queijo de pasta filada) e Baski (queijo não processado), durante 4 meses, irradiados com as doses de 1 a 58 KGy em fonte de cobalto 60 . Os resultados mostraram que os microrganismos foram satisfatoriamente destruídos, e o período de maturação do queijo Kaseri pôde ser reduzido de 15 para 12 dias (Vosniakos \& Hatziioannou, 1997).

El-Batawy et al (1988) estudaram queijo Kareish irradiado com 2,5 KGy em fonte de cobalto-60, durante quatro semanas de maturação a $6^{\circ}$ e $30^{\circ} \mathrm{C}$. As contagens totais de bactérias, coliformes, leveduras e fungos, foram reduzidas significativamente pela irradiação e diminuíram gradativamente durante o armazenamento, exceto para a contagem bacteriana total em queijos 
armazenados a $30^{\circ} \mathrm{C}$ que, após as quatro semanas, se encontraram inaceitáveis para o consumo. A radiação teve um ligeiro efeito no conteúdo de umidade e $\mathrm{pH}$.

Ibrahim et al. (1987) estudaram o queijo Ras (produzido a partir do leite fresco de cabra), irradiado com 2,5 KGy após maturação por 15, 30, 60, e 90 dias a $15^{\circ} \mathrm{C}$. A contagem total de microrganismos, a contagem de fungos e leveduras e coliformes diminuíram durante a maturação. $\mathrm{O}$ pH diminuiu durante os 30 primeiros dias e depois aumentou.

Em outro estudo foi comparado a qualidade microbiológica do queijo Ras feito com leite irradiado com $5 \mathrm{KGy}$ e com leite tratado termicamente. A irradiação gama do leite reduziu a contagem total de bactérias e esporos em 98,98\% e 95,77\%, respectivamente, e eliminou coliformes e bactérias patogênicas. Este tratamento aumentou ligeiramente a acidez e estimulou a ação proteolítica e lipolítica bacteriana durante a maturação (Abdel Baky et al., 1986).

Yüceer \& Gündüz (1980) estudaram a preservação de queijo Kashar turco com baixas doses de radiação e concluíram que doses abaixo de 1,5 KGy não causaram diferenças no sabor entre as amostras irradiadas e não irradiadas. A condição ótima para este queijo foi de dose total de 0,2-0,4 KGy, taxa de dose de 0,025 - 0,05 KGy/min e tempo de radiação de 8 minutos.

Segundo Rosenthal et al. (1983), a irradiação do queijo Gouda com dose de 0,6 KGy, reduziu a contagem total de bactérias, psicrotróficos, coliformes, fungos e leveduras, sem afetar o sabor.

Krcal et al. (1978) estudaram queijos Bryndza irradiado com 0,75 a 5,0 KG em fonte de cobalto-60. O tratamento com dose maior que $1 \mathrm{KGy}$ apresentou uma redução substancial na contagem de microrganismos, mas causou alteração no sabor (queimado, estranho, estragado). A irradiação com 0,75 KGy reduziu substancialmente a contagem (mais de 90\% da contagem total, coliformes e leveduras), mas não teve efeito nos esporos de bactérias aeróbias e anaeróbias. 
Cechi et al (1996) inocularam microrganismos patogênicos em queijos de Crescenza, Crosta Fiorita, Gorgonzola, Itálico, Mascarpone, Mussarela, Robiola e Taleggio, irradiados com diferentes doses (2, 2,5, 3, 5, 6, $10 \mathrm{kGy}$ ) com fonte de cobalto-60. Cada um foi inoculado com Escherichia coli, Salmonella typhimurium, Listeria monocytogenes, Staphylococcus aureus e Bacillus cereus individualmente. Com 3 kGy, uma redução significativa nos números dos patógenos foi observada, sem nenhum efeito prejudicial sobre organismos benéficos como bactérias lácticas e alguns fungos. E. coli, S. typhimurium e S. aureus foram eliminados com $2 \mathrm{kGy}$; com $3 \mathrm{kGy}$, os coliformes e $L$. monocytogenes.

Hashisaka et al. (1989) estudaram a sobrevivência Listeria monocytogenes inoculada em sorvete e queijo Mussarela antes do tratamento de radiação gama. As amostras foram mantidas em $-78^{\circ} \mathrm{C}$ e expostas às doses de 2 , de 4 , de 8 , de 16 , e de $32 \mathrm{kGy}$. Os valores $D_{10}$ calculados eram 1,4 kGy para o queijo do Mussarela e 2,0 kGy para o sorvete. A dose eficaz da radiação (12D) para inativação de L. monocytogenes foi de $16,8 \mathrm{kGy}$ para o queijo do Mussarela e 24,4 kGy para o sorvete.

Lamb et al (2002) estudaram o efeito da radiação gama em sanduíches de presunto e queijo inoculados com $10^{6}$ ou $10^{7} \mathrm{UFC} / \mathrm{g}$ de $\mathrm{S}$. aureus, que foram analisados após 1, 13, 27 e 39 dias do armazenamento a $4^{\circ} \mathrm{C}$. Os sanduíches irradiados com 5,9 kGy não mostraram nenhum crescimento do $S$. aureus, os sanduíches irradiados com 3,85 kGy, após 13 dias, mostraram uma redução de 6 log, e os não irradiados mostraram um aumento de 0.53 log, após 39 dias.

\subsection{Análise sensorial}

Através da análise sensorial pode-se determinar a aceitabilidade e a qualidade dos alimentos, com auxílio dos sentidos humanos como paladar e olfato. Para avaliar a qualidade; deve-se levar em conta as propriedades 
sensoriais aceitáveis, como essenciais no momento da venda e consumo do produto (Morales, 1997).

A avaliação sensorial é efetuada de maneira científica, através de métodos sensoriais, que são utilizados para medir a qualidade dos alimentos através dos sentidos humanos de uma equipe de avaliação, especialmente treinadas para analisar os diferentes atributos destes (Monteiro, 1984; Duccosky, 1996).

Os métodos sensoriais classificam-se em: métodos de diferença, métodos analíticos, métodos de sensibilidade e métodos de preferência e aceitabilidade.

O teste de aceitabilidade é utilizado principalmente para testar novos produtos, bem como para controlar a qualidade e testar o tempo de armazenamento adequado para cada tipo de produto. Nestes métodos, duas ou mais amostras são comparadas, e os valores são expressos através de uma escala de pontos (vertical ou horizontal), na qual cada ponto representa um adjetivo correspondente. Os tipos de escalas mais utilizados: escala hedônica, escala hedônica facial, escala numérica e escala estruturada. Estes testes dão a grandeza (intensidade da sensação) e a direção das diferenças entre as amostras. Através das escalas, é possível descobrir o quanto as amostras diferem entre si, e qual a amostra que apresenta maior intensidade do atributo sensorial que está sendo medido (Chaves, 1993; Mori, 1992).

Os métodos descritivos têm por objetivo descrever as propriedades sensoriais dos produtos, medindo a intensidade percebida de cada atributo por cada provador (Chaves, 1990). Os métodos de testes descritivos são usados para detectar e quantificar as características sensoriais de um produto (Mori, 1992). Esta técnica requer um painel de 5 a 10 provadores treinados, familiarizados com as características sensoriais dos produtos. Neste teste é desenvolvido um registro permanente de um produto ou dos componentes sensoriais de seus ingredientes. O perfil de características requer do julgador muita habilidade, intenso treinamento, interesse e perspicácia para poder 
distinguir características de cada amostra. Este teste faz uso de um tipo multidimensional de representação visual para mostrar diferenças e similaridades (Damásio \& Costell, 1991).

Segundo Stone \& Sidel (1985), a análise descritiva quantitativa (ADQ) é uma técnica que treina indivíduos a identificar e quantificar, em ordem de ocorrência, propriedades sensoriais dos produtos e ingredientes. O procedimento é o seguinte: inicialmente é realizado treinamento com testes de sensibilidade com gostos primários, reconhecimento, percepção, limiar, reconhecimento de odores, etc. (Lyon et al., 1992). Com auxílio de um líder, os julgadores desenvolvem a lista de atributos sensoriais que caracterizam o produto, definem, por escrito, cada termo descritivo. Após os termos definidos pela equipe de provadores devem ser agrupados com a supervisão de um coordenador. Podem-se utilizar escalas de 0-5 ou 0-10 pontos, em que os provadores situam sua avaliação (Harper, 1984). Para se caracterizar o produto, não existe o número mínimo e máximo de termos que serão utilizados na avaliação, porém, é importante que todos os termos propostos pela equipe, durante o treinamento, sejam considerados. 


\section{MATERIAL E MÉTODOS}

\subsection{Preparação do queijo Minas Frescal sob atmosfera modificada}

\subsubsection{Queijo}

Foram adquiridos $35 \mathrm{~kg}$ de queijo Minas Frescal industrializado (60 peças com aproximadamente 500-600 gramas) de um laticínio da região de Piracicaba-SP com Inspeção Federal (SIF).

\subsubsection{Fracionamento do queijo e preparação das embalagens}

Com auxílio de faca e utensílios previamente flambados, as peças de queijo foram subdividas em 3 porções de aproximadamente $200 \mathrm{~g}$ para montar as embalagens. O trabalho foi conduzido dentro de câmara de fluxo laminar. Foram preparadas amostras para três tratamentos: Controle, Vácuo e atmosfera modificada (ATM: $70 \% \mathrm{CO}_{2}$ e $30 \% \mathrm{~N}_{2}$ ). Para os tratamentos com Vácuo e ATM, as amostras foram acondicionadas em embalagens PEAD (poliestireno de alta densidade). No total foram preparadas 50 amostras para o tratamento com Vácuo, 70 para ATM e 50 em embalagem plástica comum, sob ar atmosférico, constituindo este o Controle. As amostras foram acondicionadas a $4^{\circ} \mathrm{C}$ em estufa BOD modelo 347 Fanem.

Um dia após as amostras dos tratamentos com Vácuo e ATM foram transportadas em caixas de isopor com gelo até o Instituto de Tecnologia de Alimentos (ITAL) em Campinas, onde foi realizada a formação das atmosferas 
desejadas e a selagem das embalagens, permanecendo após o tratamento em câmara frigorífica $\left(4^{\circ} \mathrm{C}\right)$ até o dia seguinte, quando foram transportadas para o laboratório de laticínios ESALQ-USP, em caixas de isopor com gelo e então armazenadas sob temperatura controlada de $4^{\circ} \mathrm{C}$ em estufa BOD.

Foram retiradas amostras para as análises microbiológicas, físicoquímicas, composição gasosa da embalagem com ATM e sensoriais, nos seguintes dias de estocagem: $1^{\circ}, 6^{\circ}, 13^{\circ}, 17^{\circ}, 21^{\circ}, 24^{\circ}, 28^{\circ}, 31^{\circ}, 35^{\circ}$ e $40^{\circ}$. Até que as amostras fossem rejeitadas sensorialmente. Em cada período, eram retiradas 5 embalagens do Controle, 5 com Vácuo e 7 com ATM. Duas embalagens de cada tratamento foram utilizadas para análises microbiológicas e físico-química, três para análise sensorial e duas, no caso do ATM, enviadas ao CETEA/ITAL em caixas de isopor com gelo para determinar a composição gasosa dentro da embalagem no mesmo dia.

\subsubsection{Formação da atmosfera modificada}

Foi realizada no Centro de Tecnologia de Embalagens (CETEA) do Instituto de Tecnologia de Alimentos (ITAL), Campinas/SP.

A composição gasosa utilizada no estudo, $70 \%$ gás carbônico $\left(\mathrm{CO}_{2}\right)$ e $30 \%$ nitrogênio $\left(\mathrm{N}_{2}\right)$ foi adquirida da empresa White Martins Gases Industriais S.A., linha alimentícia.

No acondicionamento do queijo Minas Frescal, para atmosfera modificada a Vácuo, utilizou-se uma máquina com câmara de vácuo marca Selovac, modelo CV-18, com dois bicos de injeção de gás na embalagem dotada de um vacuômetro de contato.

Nos acondicionamentos com atmosfera modificada, o vácuo aplicado inicialmente na câmara foi de 27 pol Hg. Este teor de Vácuo não causou danos ao produto, nem à embalagem e reduziu o $\mathrm{O}_{2}$ residual no espaço-livre a teores inferiores a $2 \%$. A pressão de atmosfera gasosa injetada posteriormente no interior da embalagem foi regulada $2,0 \mathrm{Kgf} / \mathrm{cm}^{2}$ na máquina e o tempo de 
injeção na embalagem de 4 segundos. Essas condições possibilitaram a obtenção de uma quantidade de gás no espaço-livre que atendia a relação de 1 a 3 litros gás/Kg de produto, recomendada por Day (1992).

As condições de termossoldagem foram: pressão nas mandíbulas de selagem de $1,8 \mathrm{Kgf} / \mathrm{cm}^{2}$ na máquina e o selador de tempo em 4 segundos. Com essas condições obteve-se uma solda com boa fusão entre os materiais internos da embalagem e boa aparência visual.

\subsection{Preparação do queijo Minas Frescal sob atmosfera modifica e irradiado}

\subsubsection{Queijo}

Também foram adquiridos $35 \mathrm{~kg}$ de queijo Minas Frescal industrializado (60 peças com aproximadamente 500-600 g.) de outro laticínio da região de Piracicaba-SP com Inspeção Federal (SIF).

\subsubsection{Fracionamento do queijo e preparação das embalagens}

O fracionamento do produto e preparação das embalagens foram conforme 0 item 3.1.2. No total foram preparadas 40 amostras para 0 tratamento Vácuo, 56 para ATM e 40 em embalagem plástica comum, sob ar

atmosférico, constituindo este o Controle. As amostras foram acondicionadas a $4^{\circ} \mathrm{C}$ em estufa BOD modelo 347 Fanem.

Um dia após, as amostras foram transportados em caixas de isopor com gelo até Instituto de Tecnologia de Alimentos (ITAL) em Campinas onde foi realizado a formação das atmosferas desejadas e a selagem das embalagens, permanecendo após isso em refrigeração $\left(4^{\circ} \mathrm{C}\right)$ até o dia seguinte, quando foram transportados para a Companhia Brasileira de Esterilização (CBE) em Jarinú, São Paulo, para a aplicação da irradiação. 
No dia seguinte, as amostras retornaram para o laboratório de laticínios da ESALQ-USP, sob gelo e então armazenados sob temperatura controlada de $4^{\circ} \mathrm{C}$ em estufa BOD.

Foram retiradas amostras para as análises microbiológicas, físicoquímicas, composição gasosa da embalagem do ATM, nos seguintes dias de estocagem, após a irradiação: $1^{\circ}, 5^{\circ}, 12^{\circ}, 19^{\circ}, 26^{\circ}, 33^{\circ}, 40^{\circ}$ e $47^{\circ}$. E as análises sensoriais eram feitas após serem obtidos os resultados das análises microbiológicas; sendo realizadas nos seguintes dias de estocagem: $5^{\circ}, 8^{\circ}, 15^{\circ}$, $22^{\circ}, 29^{\circ}, 36^{\circ}, 43^{\circ}$. As análises eram feitas até que o produto fosse rejeitado sensorial ou microbiologicamente.

Em cada semana eram retiradas 5 embalagens do Controle irradiado, 5 com Vácuo irradiado e 7 com ATM irradiado. Duas embalagens de cada tratamento foram utilizadas para análises microbiológicas e físico-química, três para análise sensorial e duas, no caso do ATM, enviadas ao CETEA/ITAL em caixas de isopor com gelo para determinar a composição gasosa dentro da embalagem.

\subsubsection{Formação da atmosfera modificada}

Foi realizada no Cento de Tecnologia de Embalagens (CETEA) do Instituto de Tecnologia de Alimentos (ITAL), Campinas/SP.

A composição gasosa foi a mesma descrita em 3.1.3.

$\mathrm{O}$ acondicionamento do queijo Minas Frescal, na atmosfera modificada e a Vácuo, foi realizado segundo o item 3.1.3.

As condições de termossoldagem foram as mesmas descritas no item 3.1.3. 


\subsubsection{Irradiação do queijo Minas Frescal sob atmosfera modificada}

Foi realizada na Companhia Brasileira de Esterilização (CBE) em Jarinú, São Paulo. Os queijos, já embalados à Vácuo, sob ATM e ar atmosférico, foram colocadas em caixa de isopor com gelos e assim mantidas durante todo o processo de irradiação.

Os queijos foram irradiados com doses de $2 \mathrm{KGy}$, no irradiador de Cobalto-60, a uma taxa de dose de $4 \mathrm{KGy} / \mathrm{h}$. A irradiação foi monitorada por dosímetros do tipo amber Batch $\mathrm{N}$ da marca Harwell.

\subsection{Análises microbiológicas}

\subsubsection{Preparo das Amostras}

Para ambos os estudos a metodologia foi a mesma.

As embalagens foram desinfetadas com etanol $70 \%$, antes de serem abertas. A unidade analítica utilizada para a análise de queijo foi de $25 \mathrm{~g}$, retirada assepticamente da amostra e transferida para um agitador estéril com $225 \mathrm{~mL}$ de água peptonada 0,1\%, utilizada para fazer as diluições decimais seriadas subseqüentes tantas quantas necessárias para a obtenção das contagens bacterianas desejadas.

\subsubsection{Staphylococcus coagulase positiva}

Para a contagem da população de Staphylococcus foi utilizado o método de semeadura em superfície no ágar Baird-Parker (MERCK) previamente adicionado de solução de gema de ovo $50 \%+0,1 \%$ telurito (LABORCLIN), a partir das diluições decimais obtidas em 3.3.1. Foi semeada uma alíquota de 1 $\mathrm{mL}$ da diluição $10^{-1}$, subdividida em 10 placas $(0,1 \mathrm{~mL} /$ placa) e espalhadas sobre a superfície do ágar com auxílio de alça de Drigalsky. Este procedimento 
foi feito para facilitar a leitura devido à elevada contaminação presente nas placas. Também foram semeadas alíquotas de $0,1 \mathrm{~mL}$, em triplicata, das diluições $10^{-2}$ a $10^{-4}$. As placas assim inoculadas foram incubadas a $35^{\circ} \mathrm{C}$ por 48 h. Após este período fez-se a contagem das colônias típicas (circulares, pretas, pequenas, rodeadas pelo uma zona opaca e um halo transparente). Estas colônias típicas foram inoculadas em caldo BHI - Brain Heart Infusion (MERCK) e incubados a 37\%/24h, para posteriores provas de confirmação de coloração de Gram, provas catalase e coagulase. Os resultados foram expressos em UFC/g (Vanderzant \& Splittstoesser, 1992).

\subsubsection{Contagem de microrganismos mesófilos aeróbios totais}

Foi utilizada a técnica de semeadura por profundidade em PCA - Ágar Padrão de Contagem (MERCK). Alíquotas de $1 \mathrm{~mL}$ das diluições decimais obtidas em 3.3.1 foram inoculadas em triplicata, sendo utilizadas 4 diluições consideradas mais apropriadas, variando-as conforme a evolução da população. Após a solidificação do ágar as placas foram incubadas a $35^{\circ} \mathrm{C}$ por 48 horas. Para contagem foram selecionadas as placas com 25-250 colônias e os resultados foram expressos em UFC/g (Vanderzant \& Splittstoesser, 1992).

\subsubsection{Contagem de microrganismos psicrotróficos aeróbios e anaeróbios totais}

Foi realizada a técnica de semeadura por profundidade em PCA - Ágar Padrão de Contagem (MERCK), conforme o descrito em 3.3.3. Neste caso, para a contagem de microrganismos psicrotróficos aeróbios, as placas foram incubadas a $7^{\circ} \mathrm{C}$ por 10 dias. Para os psicrotróficos anaeróbios a incubação foi feita em jarras de anaerobiose com o reativo de anaerobiose Anaerogen (OXOID) e incubadas também a $7^{\circ} \mathrm{C}$ por 10 dias. Para a contagem foram 
selecionadas as placas com 25-250 colônias e os resultados foram expressos em UFC/g (Vanderzant \& Splittstoesser, 1992).

\subsubsection{Contagem de coliformes totais e Escherichia coli}

Para a contagem de coliformes totais e E. coli foi utilizada a técnica de tubos múltiplos, série de três tubos. A partir das diluições decimais obtidas em 3.3.1 foi inoculado $1 \mathrm{~mL}$ das diluições $10^{-1}$ a $10^{-6}$ numa série de três tubos contendo o meio Caldo Lauril Sulfato Triptose suplementado com 50mg/L de 4metil-umbeliferil - $\beta$-D- glucuronídeo LST-MUG (MERCK), com tubos de Durham invertidos no interior. Foram incubados a $35^{\circ} \mathrm{C}$ por 24 horas e foi feita leitura sob lâmpada de luz ultravioleta ( $6 \mathrm{w}$ e $\lambda=365 \mathrm{~nm}$ ) em cabine escura. Foram considerados positivos para E. coli, todos os tubos que apresentaram fluorescência azul. O número mais provável por mililitro $(\mathrm{NMP} / \mathrm{mL})$ foi obtido numa tabela NMP apropriada às diluições inoculadas, sendo o resultado expresso em NMP/g (Vanderzant \& Splittstoesser, 1992).

Para confirmação de coliformes totais, o conteúdo dos tubos suspeitos do LST-MUG (formação de gás), foi transferido com alça microbiológica para tubos com caldo Verde Brilhante Bile (VB, MERCK) e incubados a $35^{\circ} \mathrm{C}$ por 24/48h. Foram considerados positivos os tubos que apresentaram crescimento e formação de gás. O número mais provável por mililitro $(\mathrm{MNP} / \mathrm{mL})$ foi obtido em tabela NMP apropriada às diluições inoculadas, sendo o resultado expresso em NMP/g (Vanderzant \& Splittstoesser, 1992).

\subsection{Análises físico-químicas}

No experimento com queijo sob atmosfera modificada inicialmente foram feitas análises físico-químicas de $\mathrm{pH}$, acidez, gordura, extrato seco total, umidade, cinzas, gordura total e rancidez. E durante o período de estocagem 
eram apenas realizadas as análises de $\mathrm{pH}$, acidez e rancidez, nos três tratamentos (ATM, Vácuo e Controle).

No experimento com queijo sob atmosfera modificada e irradiado inicialmente foram feitas análises físico-químicas de $\mathrm{pH}$, acidez, gordura, extrato seco total, umidade, cinzas, gordura total e rancidez, no queijo antes e depois de ser irradiado. Durante o período de armazenamento eram apenas realizadas as análises de $\mathrm{pH}$, acidez e rancidez nos queijos irradiados sob ATM, Vácuo e do Controle.

\subsection{1 pH}

Foi determinado segundo Lanara, utilizando uma mistura de $10 \mathrm{~g}$ de queijo com $50 \mathrm{~mL}$ de água a $25^{\circ} \mathrm{C}$ e leitura foi efetuada após 30 minutos em potenciômetro digital (Brasil, 1981).

\subsubsection{Acidez}

Foi determinada por titulação com $\mathrm{NaOH}$ através do método descrito pela A.O.A.C. (1995), e expressos em \% de ácido láctico.

\subsubsection{Extrato seco total (EST) e umidade}

Foi realizada segundo o método de secagem das amostras até peso constante, em estufa a $105^{\circ} \mathrm{C}$ (A.O.A.C., 1995).

\subsubsection{Gordura}

O teor de gordura foi determinado pelo método volumétrico de Gerber segundo as Normas Analíticas do Instituto Adolfo Lutz (Pregnolatto \& Pregnolatto, 1985). 


\subsubsection{Gordura no extrato seco (GES)}

Esta foi calculada pela fórmula da A.O.A.C. (1995):

$$
\text { GES }=\frac{\% \text { de gordura } \times 100}{\% \text { de extrato seco total }}
$$

\subsubsection{Proteína total}

A quantidade de nitrogênio total nas amostras, foi determinada, pelo método oficial de Kjedahl, e multiplicando-se por 6,38 para obter o teor de proteína total segundo a A.O.A.C. (1995).

\subsubsection{Resíduo mineral fixo (cinzas):}

Foi determinado segundo as Normas Analíticas do Instituto Adolfo Lutz (Pregnolatto \& Pregnolatto, 1985).

\subsubsection{Rancidez}

Foi feita através da Reação de Kreiss segundo as Normas Analíticas do Instituto Adolfo Lutz (Pregnolatto \& Pregnolatto, 1985).

\subsection{Análises de composição gasosa do espaço-livre}

A técnica utilizada na determinação da composição gasosa do interior das embalagens consistiu na coleta de alíquotas de $300 \mu \mathrm{l}$ de gás do espaçolivre com seringa hermética, através de um septo colado na embalagem, e posterior identificação e quantificação dos gases em cromatógrafo a gás Shimadzu, modelo $14 A$, operando com detector de condutividade térmica a 
$150^{\circ} \mathrm{C}$, colunas (Peneira Molecular $13 \mathrm{X}$ e Porapak $N$ ) a $50^{\circ} \mathrm{C}$ e injetor a $70^{\circ} \mathrm{C}$. Os resultados de cromatografia foram analisados por um integrador Shimadzu, modelo $C R 4 A$, com base em curvas padrões feitas com gases de calibração. Os resultados foram expressos em termos de porcentagem em volume de gás. Esta análise foi realizada pela equipe do CETEA/ITAL.

\subsection{Análises sensoriais}

\subsubsection{Análises sensoriais utilizadas para o queijo Minas Frescal sob atmosfera modifica}

Foi realizado teste de aceitabilidade com 30 julgadores não treinados, utilizando escala hedônica de 9 pontos tendo como extremidades gostei (9) e desgostei extremamente (1) (Dutcosky, 1996). Através da análise sensorial foi medido o atributo de cor, aparência geral, odor das amostras e aparência geral do produto dentro da embalagem. As três amostras foram apresentadas aos provadores, em formatos de cubos, de forma monódica e seqüencial. As análises foram realizadas em cabines individuais com luz branca e as amostras foram codificadas com três dígitos (Morales, 1997). O modelo de ficha apresentado aos provadores para a avaliação sensorial pode ser observado na Figura 1. 


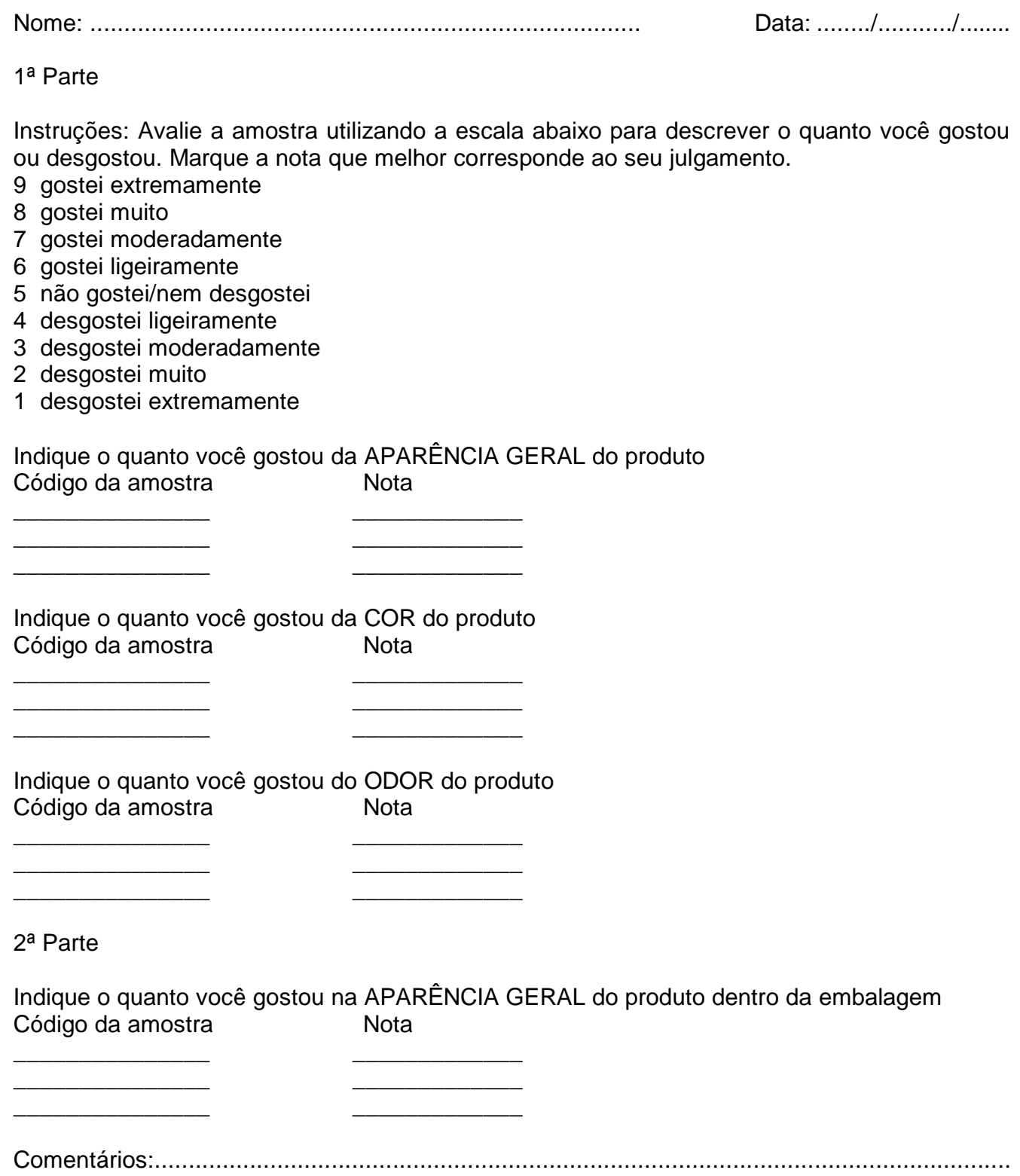

Figura 1 - Ficha de avaliação sensorial apresentada aos provadores. 


\subsubsection{Análises sensoriais utilizadas para o queijo Minas Frescal sob atmosfera modifica e irradiado}

As análises sensoriais foram desenvolvidas em duas etapas distintas, sendo que na $1^{\circ}$ etapa, realizou-se a seleção e treinamento dos provadores, e na $2^{\circ}$ etapa, a avaliação sensorial dos atributos do queijo de diferentes tratamentos, através da "Análise Sensorial Descritiva" (A.D.Q.), usando uma escala não estruturada de 0 a $10 \mathrm{~cm}$ (Stone et al., 1976).

\subsubsection{Seleção dos provadores}

$\mathrm{Na}$ seleção dos provadores aplicou-se dois métodos analíticos de diferença, inicialmente fez-se teste de reconhecimento de sabores e após teste de sensibilidades para gosto.

No teste de conhecimentos de sabores utilizou-se, como material, soluções quimicamente puras de gostos básicos: doce (2\% de sacarose), ácido ( $0,07 \%$ de ácido cítrico), salgado ( $0,2 \%$ de cloreto de sódio) e amargo (0,07\% de cafeína) (Gurgel et al., 2000). Essas soluções e mais água mineral foram oferecidas aos provadores em copos plásticos arranjados aleatoriamente em bandejas. Através de um tabela de números aleatórios de três algarismos, foram identificadas alíquotas de $25 \mathrm{~mL}$ para cada um dos estímulos.

Este teste foi realizado em cabines individuais, com luz vermelha. Cada cabine continha as amostras, ficha de avaliação (Figura 2), copo com e água e bolacha água e sal para limpeza da boca entre as avaliações. 


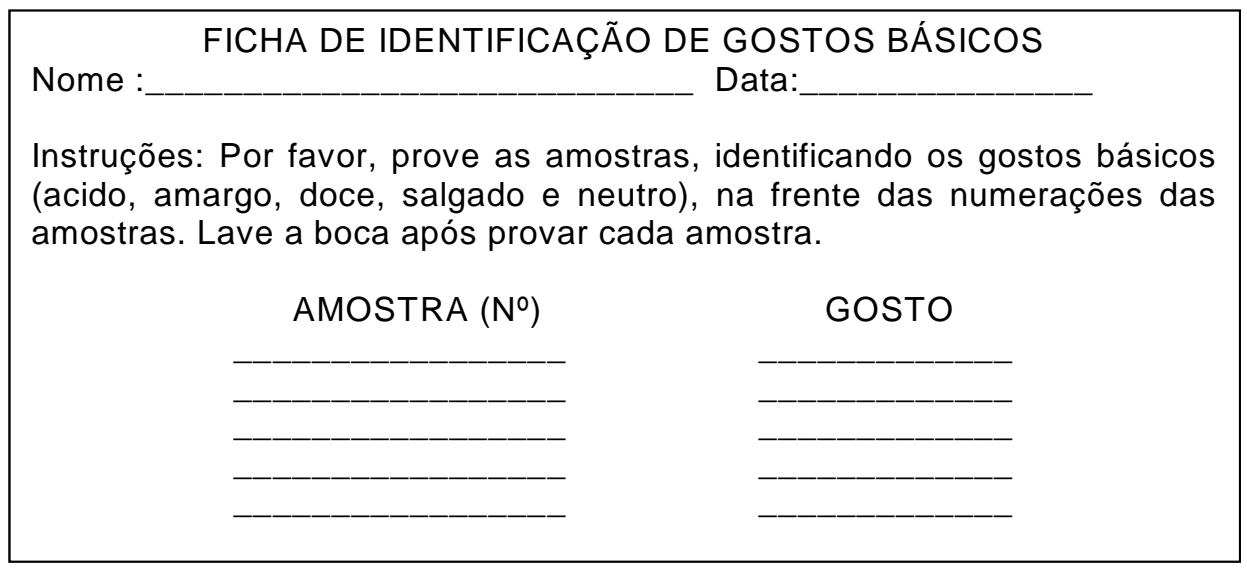

Figura 2 - Ficha sensorial utilizada na seleção de provadores para identificação de gostos básicos.

No teste de sensibilidade para gosto, utilizou-se o teste triangular (Garruti, 1976) com soluções salinas a 0,07\% e 0,05\% e soluções de ácidas a $0,07 \%$ e $0,05 \%$. Foram realizadas seis combinações por provador. O teste triangular foi conduzido nas mesmas condições descritas para o teste de reconhecimento de sabores (Gurgel et al., 2000). A Figura 3 apresenta o modelo de ficha para este teste.

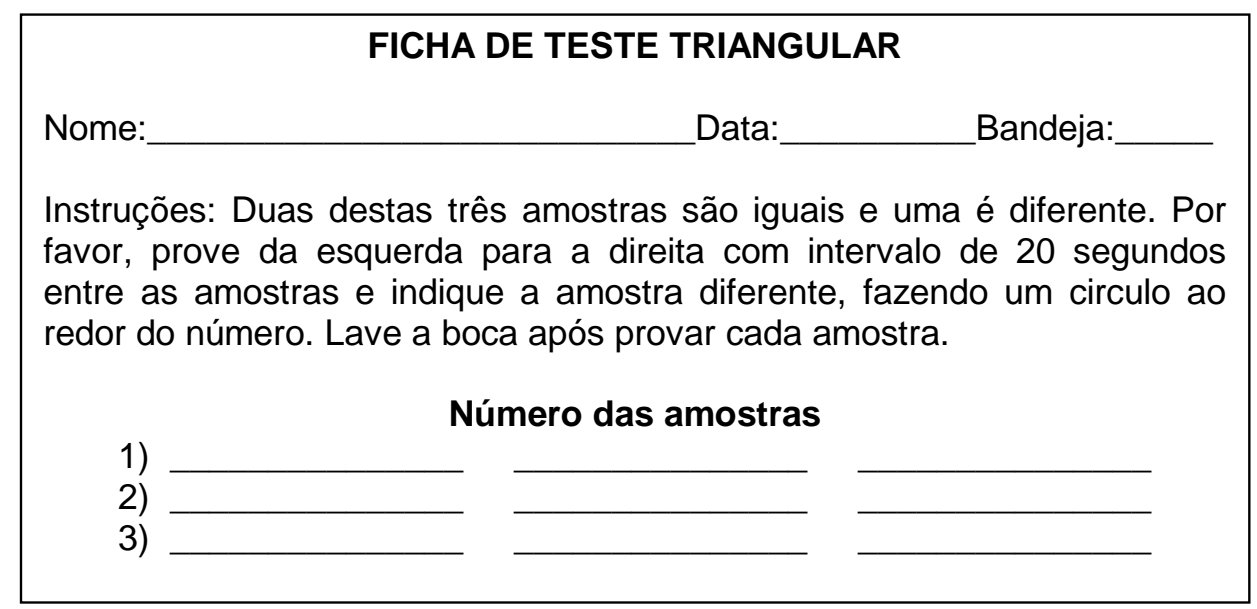

Figura 3 - Ficha sensorial utilizada na seleção de provadores para sensibilidade dos gostos. 
Foram selecionados apenas os provadores que acertaram mais de $80 \%$ em todos os testes realizados. Sendo selecionados um total de 12 provadores para a etapa de treinamento, onde 7 eram mulheres e 5 homens.

\subsubsection{Treinamento dos provadores}

Após a seleção dos provadores, procedeu-se a fase de treinamento iniciada com a apresentação dos objetivos do experimento, a importância da presença e da assiduidade de cada um. Foram explicados alguns aspectos da análise sensorial, como a identificação dos atributos sensoriais de aparência, textura, aroma e sabor, sensação da boca e residual.

Para o treinamento dos provadores foi apresentada, a lista de definições dos termos descritivos para os atributos de aparência, textura e sabor do queijo Minas Frescal irradiado, segundo Gurgel (2000). Assim, os provadores foram treinados utilizando os parâmetros contidos nesta lista (Figura 4). Foram necessárias 8 sessões de treinamento onde, em duas sessões treinou-se a aparência, noutras duas a textura e mais duas o sabor. Após essas sessões, foram feitas duas nas quais treinaram-se todos os atributos. Para medir a intensidade de cada atributo, foi utilizada uma escala estruturada de 0 a $10 \mathrm{~cm}$, (Cone et al, 1974), para a Análise Descritiva Quantitativa, apresentada na Figura 5. 


\section{APARÊNCIA}

COR: refere-se a brancura da amostra, variando de branco à branco amarelado.

Parâmetros: folha de papel (branco) e queijo meia-cura (branco amarelado)

FRESCOR: refere-se em caracterizar a idade da amostra, variando de queijo velho à queijo

fresco.

Parâmetros: queijo minas com 25 dias de estocagem (queijo velho) e queijo Danúbio (queijo

fresco)

FIRMEZA: refere-se em caracterizar a força necessária para penetrar o produto com dente molar, variando de pouca a muita firmeza.

Parâmetros: queijo Danúbio (pouca firmeza) e queijo parmesão (muita firmeza).

BRILHO: refere-se em caracterizar a qualidade de reflexão de luz, variando de pouco à muito brilho.

Parâmetros: ricota (pouco brilho) e queijo Danúbio (muito brilho).

AERADO: refere-se em caracterizar a presença de bolhas de ar (furos) na amostra, variando de pouco a muitos furos.

Parâmetros: queijo Danúbio (poucos furos) e queijo-meia curam (muitos furos).

SOROSO: refere-se em caracterizar a presença de soro na amostra, variando de pouco à muito soro.

Parâmetros: ricota (pouco soro) e queijo minas frescal comercial (muito soro).

CREMOSO: refere-se em caracterizar a cremosidade da amostra, variando de pouco à muito cremoso.

Parâmetros: ricota (pouco cremoso) e queijo Polenguinho ou Catupiry (muito cremoso).

\section{TEXTURA}

ESFARELENTO: refere-se em caracterizar a amostra quanto a sua capacidade de esfarelar ou desfazer, variando de pouca à muito esfarelento.

Parâmetros: queijo Catupiry (pouco esfarelento) e ricota (muito esfarelento).

CONSISTÊNCIA: refere-se em caracterizar a amostra quanto a sua consistência e/ou firmeza, variando de baixa a alta consistência.

Parâmetros: queijo Catupiry (baixa consistência) e queijo Parmesão (alta consistência).

BORRACHUDO: refere-se em caracterizar a amostra quanto a propriedade de elasticidade, variando de pouco a muito borrachudo.

Parâmetros: ricota (pouco borrachudo) e queijo mussarela palito (muito borrachudo).

CREMOSO: refere-se em caracterizar a textura da amostra, variando de pouco a muito cremoso.

Parâmetros: ricota (muito cremoso) e queijo Polenguinho ou Catupiry (muito cremoso).

\section{SABOR}

AZEDO: refere-se em caracterizar a acidez da amostra, variando de pouco a muito azedo.

Parâmetros: ricota (pouco azedo) e iogurte natural Danone (muito azedo).

AMARGO: refere-se em caracterizar o amargor da amostra, variando de pouco a muito amargo.

Parâmetros: ricota (pouco amargo) e cafeína 0,05\% (muito amargo).

CARACTERISTICA DE QUEIJO FRESCAL: refere-se em caracterizar a amostra quanto ao sabor e aroma característico de queijo frescal, variando de pouco a muito característico.

Parâmetros: queijo com 25 dias de armazenamento (pouco característico) e queijo fresco muito característico.

SALGADO: refere-se em caracterizar o teor de sal na amostra, variando de pouco a muito salgado.

Parâmetros: ricota (pouco salgado) e queijo minas frescal com 2,5\% de sal (muito salgado). DOCE: refere-se em caracterizar o quanto a amostra apresenta o sabor adocicado, variando de pouco a muito doce.

Parâmetros: ricota (pouco doce) e leite fervido por 30 min. (muito doce).

SABOR ESTRANHO: refere-se a sabores não definidos, variando de pouco a muito acentuado.

Figura 4 - Lista de definições dos termos descritivos para os atributos de aparência, textura, aroma e sabor de queijo Minas Frescal irradiado. 


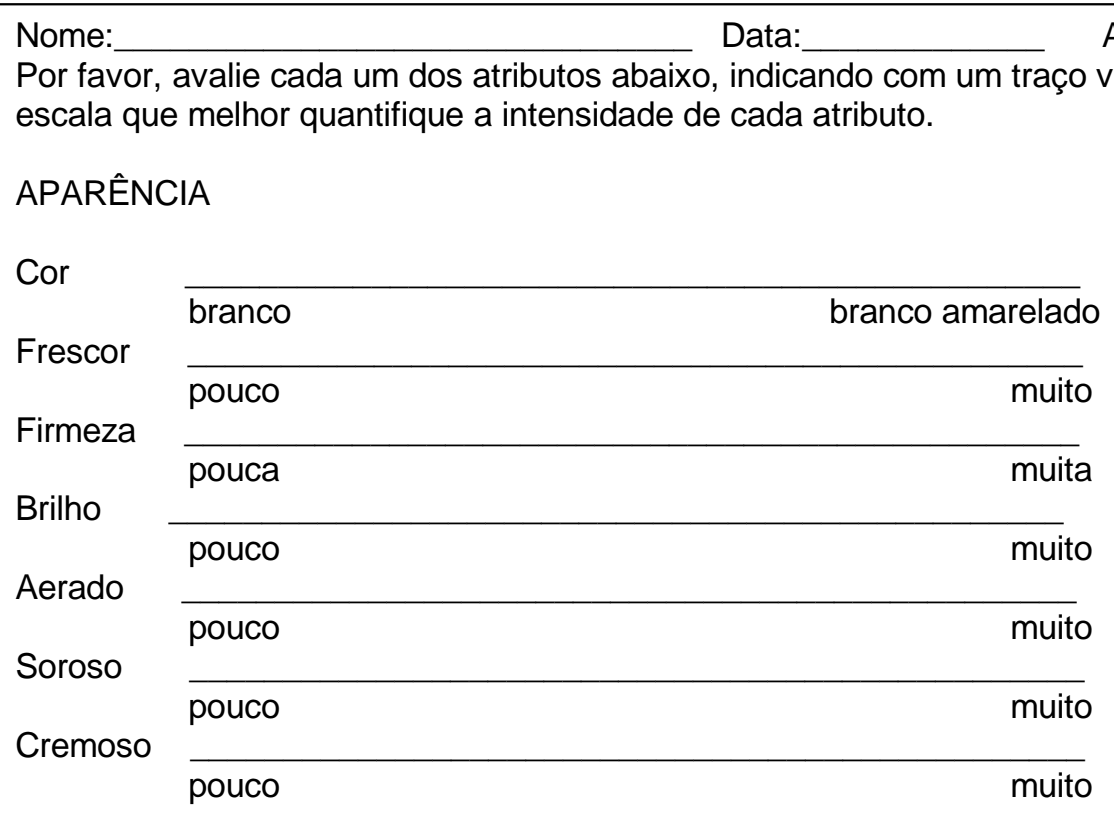

\begin{tabular}{llc} 
TEXTURA & & \\
Esfarelento & & muito \\
\cline { 2 - 3 } Consistência & pouco & alta \\
\cline { 2 - 3 } Borrachudo & baixa & muito \\
\cline { 2 - 3 } Cremoso & pouco & muito
\end{tabular}

\begin{tabular}{|c|c|c|}
\hline \multicolumn{3}{|c|}{$\begin{array}{l}\text { AROMA E SABOR } \\
\text { Azedo }\end{array}$} \\
\hline \multirow{3}{*}{$\begin{array}{l}\text { Amargo } \\
\text { Característico }\end{array}$} & pouco & muito \\
\hline & pouco & muito \\
\hline & pouco & muito \\
\hline & & \\
\hline & pouco & muito \\
\hline \multirow{2}{*}{$\begin{array}{l}\text { Doce } \\
\text { Sabor estranho }\end{array}$} & pouco & muito \\
\hline & & muito \\
\hline
\end{tabular}

Figura 5 - Ficha de Análise Descritiva Quantitativa do queijo Minas Frescal irradiado. 


\subsubsection{Avaliação do experimento}

As análises foram realizadas em cabines individuais com luz branca e as amostras foram codificadas com três dígitos. As três amostras foram apresentadas aos provadores, em formatos de cubos em pratos de porcelana, de forma monódica e seqüencial. Cada cabine continha a amostra, ficha de avaliação (Figura 5), copo com e água e bolacha água e sal para limpeza da boca entre as avaliações.

Dos 12 provadores treinados, apenas 8 participaram da avaliação do experimento, sendo 4 homens e 4 mulheres. O experimento durou 8 semanas até que a última amostra fosse rejeitada.

\subsubsection{Análise estatística}

Os resultados obtidos da análise sensorial foram analisados conforme o esquema da análise de variância com aplicação do teste $\mathrm{F}$ e análise estatística teve continuidade quando o teste $\mathrm{F}$ foi significativo ao nível de $5 \%$, através do teste de Tukey. Antes da realização da análise de variância foi feita a homogeneidade dos dados onde foram retirados os valores discrepantes. Para a análise estatística dos dados utilizou-se o software SAS (1988). 


\section{RESULTADOS E DISCUSSÃO}

\subsection{Análises microbiológicas}

\subsubsection{Qualidade da matéria-prima utilizada no experimento com atmosfera modificada}

$\mathrm{Na}$ Tabela 1 estão demonstrados os resultados das contagens microbianas iniciais do queijo Minas Frescal utilizado no experimento. Por meio desta pode-se verificar que o queijo adquirido para o experimento estava com contagens microbiológicas acima do estabelecido pela Resolução RDC $n^{0} 12$, de 2 de Janeiro de 2001 para queijos de umidade muita alta: máx. de 2,6 log de UFC/g para coliformes fecais e 2,6 log de NMP/g Staphylococcus coagulase positiva (ANVISA, 2001). Isto pode ter sido provocado pela má qualidade da matéria-prima e pelas más condições de higiene durante o processamento do produto.

$\mathrm{Na}$ Tabela 1 pode ser observado que o produto adquirido tinha uma elevada população tanto de bactérias mesófilas (6,4 log de UFC/g) quanto de psicrotróficas aeróbios (5,6 log de UFC/g). Essas elevadas contagens podem indicar que o queijo foi preparado com matéria-prima altamente contaminada e/ou que o processamento foi insatisfatório do ponto de vista higiênico (Leite Jr. et al., 2000). Entretanto, a presença de elevada população de bactérias mesófilas não é critério para analisar as condições sanitárias de produtos 
lácteos fermentados, em cujo processamento são utilizados esses microrganismos (Feitosa, 1985).

Tabela 1. Resultado da contagem microbiana inicial do queijo Minas Frescal.

\begin{tabular}{lc}
\hline \multicolumn{1}{c}{ Microrganismos } & Valores \\
\hline Bactérias mesófilas aeróbias (log UFC/g) & 6,48 \\
Bactérias psicrotróficas aeróbias (log UFC/g) & 5,67 \\
Bactérias psicrotróficas anaeróbias (log UFC/g) & 6,06 \\
Coliformes totais (log NMP/g) & 4,32 \\
Escherichia coli (log NMP/g) & 3,32 \\
Staphylococcus coagulase positiva (log UFC/g) & 3,47 \\
\hline
\end{tabular}

O queijo Minas Frescal utilizado no experimento teve contagem de $S$. coagulase positiva de 3,4 log de UFC/g (Tabela 1) a qual foi superior ao limite estabelecido pela legislação (2,6 log de UFC/g). Comparando esse resultado ao encontrado pela literatura, verificou-se que, das 80 amostras analisadas por Almeida Filho \& Nader Filho (2000), 40 (50\%) apresentaram contagens de Staphylococcus aureus acima de $10^{3} \mathrm{UFC} / \mathrm{g}$. O mesmo ocorreu em trabalhos realizados por Rodrigues et al. (1995), Cerqueira et al. (1995) e Sabione (1993), os quais, respectivamente observaram que $100 \%, 60 \%$ e $21,5 \%$ das amostras do queijo tipo Minas Frescal apresentaram contagem de $S$. aureus acima do padrão legal.

Ressalta-se, portanto, o risco que significa a presença desses microrganismos em produtos alimentícios de origem animal, como lácteos. Sua presença nesses alimentos pode ser considerada como indicadora de contaminação de fossas nasais, boca e pele de manipuladores, podendo ocasionar intoxicação alimentar (Roitman et al., 1988).

Para a contagem de coliformes totais foi encontrado valor de 4,3 log de UFC/g (Tabela 1), a legislação brasileira não estabelece limite de tolerância de 
coliformes totais em queijos. Entretanto, Lück (1987) destacou a importância da contagem de coliformes para avaliar a ocorrência de contaminações durante o processamento de produtos lácteos, de modo geral, considerando que estes microrganismos, comumente encontrados no leite cru, são destruídos pelo calor de pasteurização. Assim, muito provavelmente a contaminação no produto adquirido foi devido às más condições de higiene durante o processamento e manipulação do produto.

A contagem de Escherichia coli foi de 3,3 log de UFC/g (Tabela 1), sendo superior ao limite estabelecido pela legislação. Essa contagem significa que as condições sanitárias eram deficientes, havendo a possibilidade de presença de microrganismos patogênicos, com risco à saúde do consumidos. Outros autores já detectaram índices de coliformes fecais superiores ao limite permitido pela legislação. Isso mostra que há uma grande incidência deste grupo em queijos Minas Frescal sendo de extrema importância os cuidados higiênicos e sanitários no processamento (Raimundo, 1992; Tavares \& Garcia, 1993; Gomes \& Gallo 1995; Santos et al., 1995; Rodrigues et al., 1995; Oliveira et al., 1998; Borelli et al., 2000 e Leite Jr. et al. 2000).

Este queijo em condições microbiológicas desfavoráveis foi utilizado no experimento, porque não havia condições estruturais para processar a quantidade necessária para o experimento, e, quando os resultados das análises microbiológicas ficaram prontos não havia mais tempo para retornar 0 produto. Assim, acompanhou-se o comportamento da microbiota presente no produto adquirido do laticínio. Devido a esses problemas, as análises sensoriais restringiram-se a características de aparência e odor.

\subsubsection{Comportamento da população microbiana no queijo Minas Frescal sob atmosfera modificada}

\subsubsection{Evolução da população de mesófilos aeróbios totais}


$\mathrm{Na}$ Figura 6 observa-se o comportamento da população de microrganismos mesófilos aeróbios no queijo sob os três tratamentos em que se verifica que no Controle a população aumentou progressivamente de 7,2 até 9,5 log de UFC/g durante 17 dias. Após um rápido crescimento \pm 1 ciclo logarítmico) entre $01^{\circ}$ e $13^{\circ}$ dia de armazenamento, a população tendeu a se estabilizar, aumentando 0,9 log de UFC/g para a ATM e 0,6 log de UFC/g para o Vácuo até o $31^{\circ}$ dia. A partir deste dia as contagens diminuíram para esses dois tratamentos não ultrapassando 8,9 log de UFC/g, ao fim dos 40 dias de armazenamento. A diminuição do crescimento ocorreu provavelmente devido à diminuição do teor de oxigênio que dificultou o desenvolvimento destes microrganismos (Daniels et al., 1985).

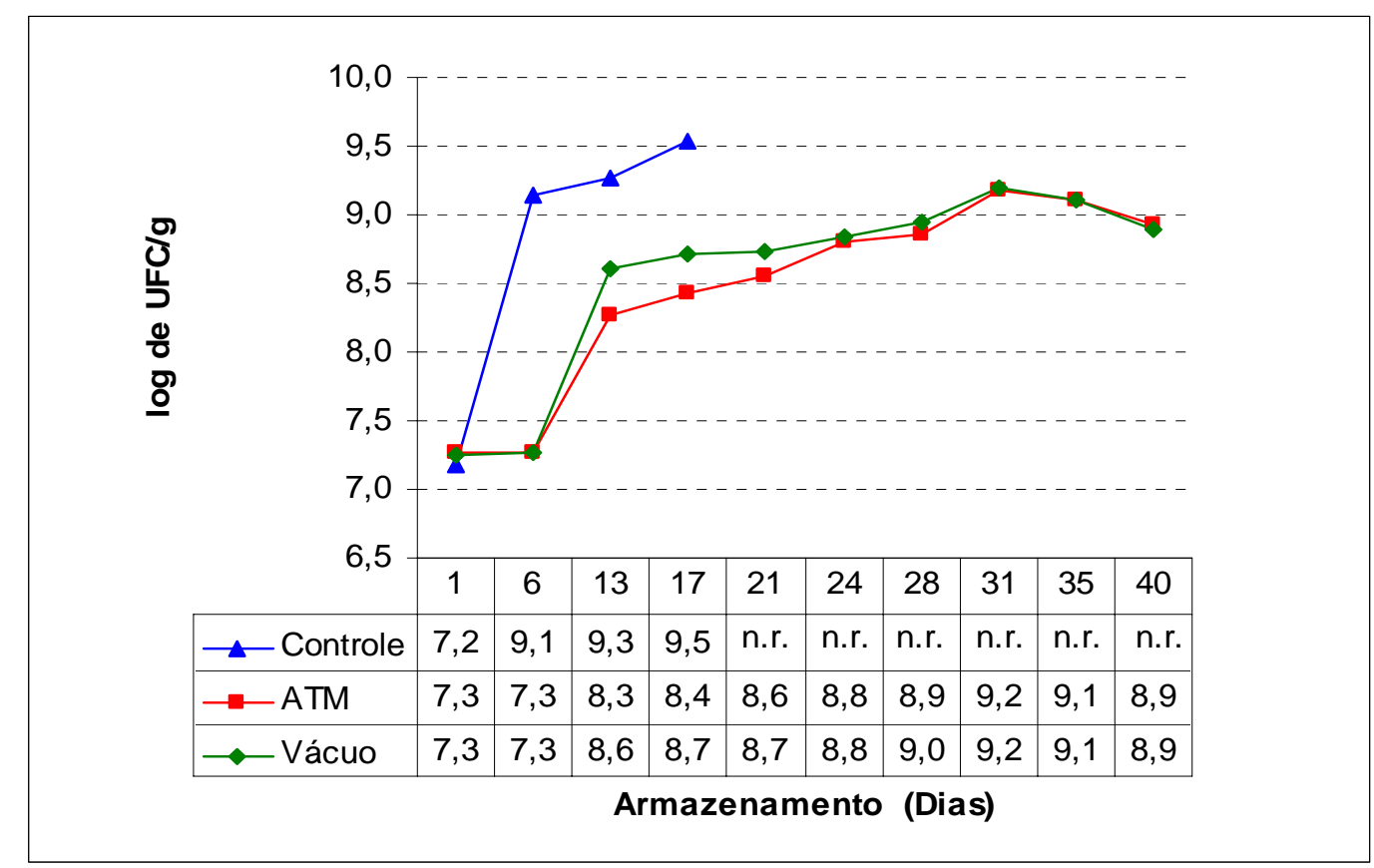

Figura 6 - Evolução da população de microrganismos mesófilos aeróbios totais em queijos Minas Frescal embalados sob ar atmosférico (Controle), Vácuo e atmosfera modificada (ATM: $70 \% \mathrm{CO}_{2} / 30 \% \mathrm{~N}_{2}$ ) durante o armazenamento a $4^{\circ} \mathrm{C}$.

n.r.: análise não realizada. 
O mesmo comportamento das bactérias mesófilas aeróbias aconteceu no trabalho Eliot et al. (1998) com queijo Mussarela em que os tratamentos (Vácuo e ATM: $75 \% \mathrm{CO}_{2}$ ) mantiveram a contagem inicial de 7,4 log de UFC/g por um período maior (8 semanas) em relação ao Controle.

A partir do $13^{\circ}$ dia a população de mesófilos aeróbios cresceu em menor velocidade na atmosfera modificada e no Vácuo em relação ao Controle e o mesmo pode ser observado no trabalho realizado por Fandos et al. (2000) em queijo de cabra sob ATM $\left(60 \% \mathrm{CO}_{2} / 40 \% \mathrm{~N}_{2}\right)$ em que a população de mesófilos aeróbios aumentou rapidamente, ficando acima de $7 \log$ de UFC/g após 14 dias de estocagem a $4^{\circ} \mathrm{C}$ e esta contagem estabilizou-se até por 28 dias nos queijos sob ATM e Vácuo.

Observa-se, portanto, que os tratamentos ATM e Vácuo diminuíram a velocidade de multiplicação das bactérias mesófilas aeróbias, a partir do $13^{\circ}$ dia, já o Controle permitiu um crescimento vertiginoso da população mesófila aeróbia.

\subsubsection{Evolução da população de psicrotróficos aeróbios totais}

$\mathrm{Na}$ Figura 7 observa-se o comportamento da população dos microrganismos psicrotróficos aeróbios nos três tratamentos. No Controle a população teve um aumento contínuo de 6,1 até 9,3 log de UFC/g durante os 17 dias de estocagem, enquanto a contagem nos queijos com ATM e a Vácuo, manteve-se controlada a partir do $6^{\circ}$ dia. Após esse período, aumentou apenas 0,82 e 0,73 ciclos logarítmicos respectivamente para ATM e Vácuo, até o final do armazenamento. Isso pode ser atribuído à ausência de oxigênio no espaçolivre, inibindo os microrganismos aeróbios e também às propriedades bacteriostáticas do gás carbônico (Daniels et al., 1985), o qual é inibidor deste tipo de microrganismo durante a estocagem (Alves et al. 1996). 


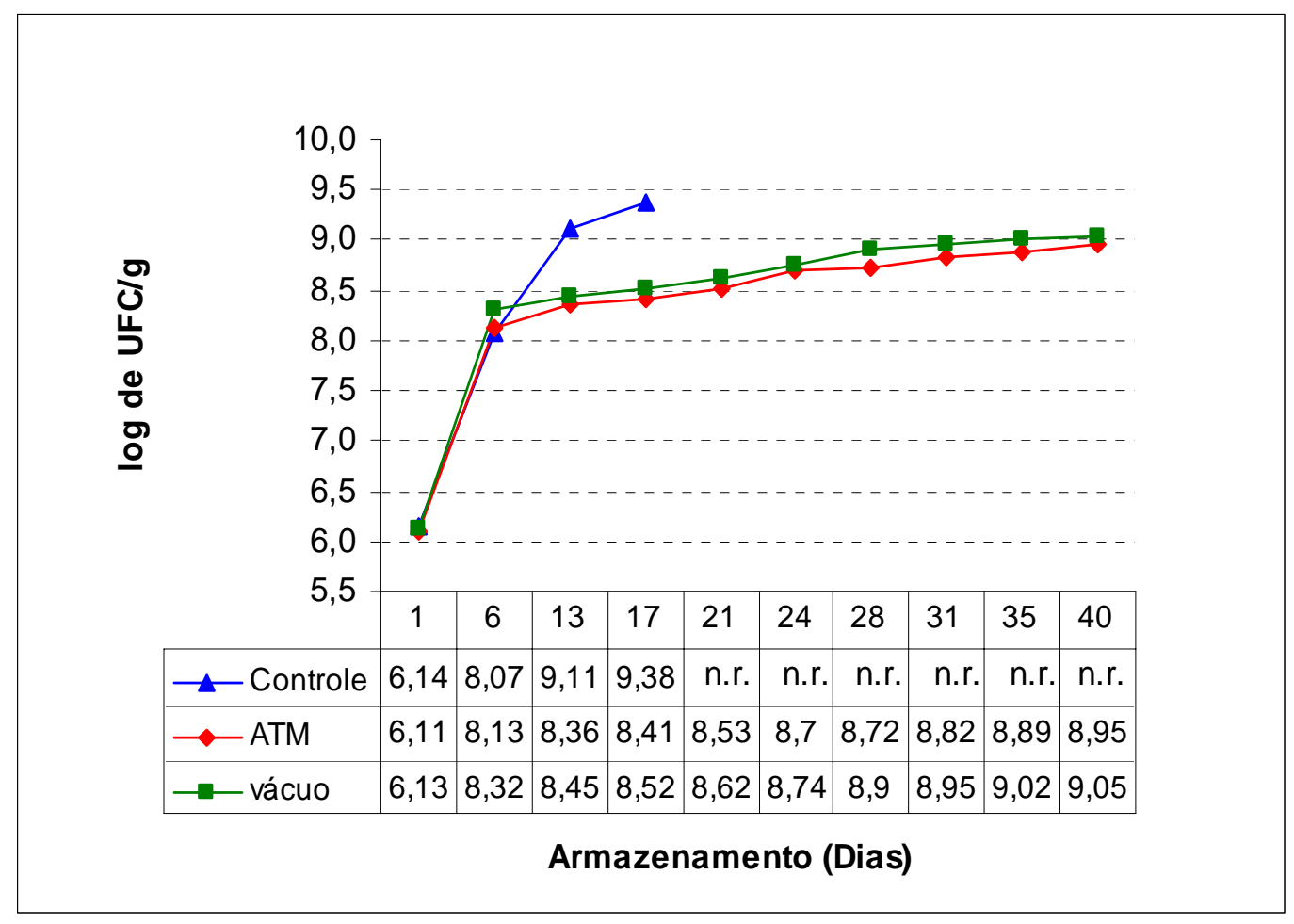

Figura 7 - Evolução da população de psicrotróficos aeróbios em queijos Minas Frescal embalados sob ar atmosférico (Controle), Vácuo e atmosfera modificada (ATM: $\left.70 \% \mathrm{CO}_{2} / 30 \% \mathrm{~N}_{2}\right)$ durante o armazenamento a $4^{\circ} \mathrm{C}$.

n.r.: análise não realizada.

No trabalho realizado por Fandos et al. (2000), em queijo de leite de cabra, verificaram que o crescimento de psicrotróficos foi menor quando a concentração de $\mathrm{CO}_{2}$ aumentava, havendo um aumento de 3,1 ciclos logarítmicos para $20 \%$ de $\mathrm{CO}_{2}$, de 3 ciclos logarítmicos sob ATM $60 \%$ de $\mathrm{CO}_{2}$, e 2,43 ciclos logarítmicos sob ATM de $100 \%$ de $\mathrm{CO}_{2}$. Esses resultados foram similares aos encontrados neste experimento, em que, com uma ATM de $70 \%$ de $\mathrm{CO}_{2}$, houve um aumento de 2,8 ciclos logarítmicos. 
Mannheim \& Soffer (1996), com queijo Cottage embalado sob ATM 25\% de $\mathrm{CO}_{2}$ armazenado a $8^{\circ} \mathrm{C}$, verificaram que houve um aumento de 3 ciclos logarítmicos na população de psicrotróficos aeróbios durante 25 dias de estocagem. Este aumento, no mesmo período, foi maior em relação ao encontrado no presente trabalho, provavelmente devido à concentração de $\mathrm{CO}_{2}$ ser baixa e a temperatura mais elevada do que a usada no presente estudo.

Eliot (1998) também encontrou um aumento de 2,5 ciclos logarítmicos desta população em queijos com atmosfera modificada. Isso pode ter ocorrido em função da temperatura de estocagem usada $\left(10^{\circ} \mathrm{C}\right)$, pois o efeito inibitório do $\mathrm{CO}_{2}$ diminui com o aumento da temperatura, aumentando a solubilidade do $\mathrm{CO}_{2}$ em baixas temperaturas (Moir et al., 1993).

Moir et al. (1993) inocularam Pseudomonas em queijo Cottage embalado sob atmosfera modificada de $40 \%$ de $\mathrm{CO}_{2}$ e armazenados a $5^{\circ} \mathrm{C}$. Verificaram que a população inicial de $10^{3} \mathrm{UFC} / g$ aumentou 2 ciclos, este aumento foi menor em relação ao do presente estudo, provavelmente devido à contagem inicial ser inferior a encontrada neste trabalho. Já em temperaturas mais elevadas $\left(15^{\circ} \mathrm{C}\right)$, esta população aumentou mais de 3 ciclos logarítmicos durante 15 dias de estocagem. Os mesmos autores inocularam Listeria monocytogenes $\left(10^{2} \mathrm{UFC} / \mathrm{g}\right)$ em queijo Cottage a $15^{\circ} \mathrm{C}$ embalado sob ATM de $40 \%$ de $\mathrm{CO}_{2}$ e verificaram que não houve crescimento sob ATM nem para o Controle durante os 30 dias de estocagem.

Também foi observado por Maniar et al. (1994), em queijo tipo Cottage embalado sob atmosfera modificada, que a contagem inicial dos psicrotróficos

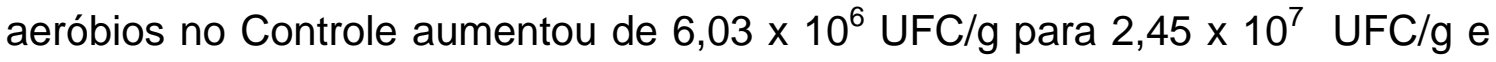
no queijo embalado sob atmosfera de $75 \% \mathrm{CO}_{2}$ e $25 \% \mathrm{~N}_{2}$ a contagem permaneceu estável durante 28 dias. Os autores concluíram que a proliferação microbiana foi dificultada pela alta concentração de $\mathrm{CO}_{2}$.

No estudo com queijo Cottage sob atmosfera modificada $\left(100 \% \mathrm{CO}_{2}\right)$, realizado por Kosikowski \& Brown (1973), a população de bactérias psicrotróficas manteve-se estável por um período maior (112 dias) que o 
encontrado no presente trabalho. Alves et al. (1996) também encontraram um período maior (51 dias) para a estabilização desta população em queijo Mussarela embalado sob atmosfera de $50 \% \mathrm{CO}_{2} / 50 \% \mathrm{~N}_{2}$.

Em trabalhos em que houve inoculação de psicrotróficos, como $L$. monocytogenes e Pseudomonas, foi observado que a ausência de oxigênio também inibiu o crescimento destes (Chen \& Hotchkiss, 1993).

Assim, verifica-se, que o uso de ATM $\left(70 \% \mathrm{CO}_{2}\right.$ e $\left.30 \% \mathrm{~N}_{2}\right)$ e o Vácuo retardaram o desenvolvimento das bactérias psicrotróficas aeróbias durante 40 dias de estocagem, enquanto que o Controle permitiu o crescimento deste grupo bacteriano.

\subsubsection{Evolução da população de psicrotróficos anaeróbios totais}

Na Figura 8 estão demonstrados os resultados das contagens de microrganismos psicrotróficos anaeróbios, sendo verificando-se um crescimento contínuo deste grupo bacteriano para os dois tratamentos utilizados (Vácuo e ATM). As contagens iniciais foram de 6,7 log UFC/g e as finais de 7,9 e 7,6 log UFC/g, respectivamente para ATM e Vácuo. Portanto, os tratamentos utilizados permitiram o crescimento contínuo do primeiro ao último dia deste grupo, devido às condições favoráveis de ausência de oxigênio e temperatura baixa para o desenvolvimento dos microrganismos anaeróbios psicrotróficos.

Olarte et al. (2002) estudaram queijo de cabra sob diversas ATMs e verificaram que em atmosfera de $100 \%$ de $\mathrm{CO}_{2}$ a população de psicrotróficos anaeróbios aumentou dois ciclos logarítmicos durante 28 dias de armazenamento, já no presente trabalho com ATM de $70 \%$ de $\mathrm{CO}_{2}$ houve um aumento menor de (1,2 ciclos logarítmicos). 


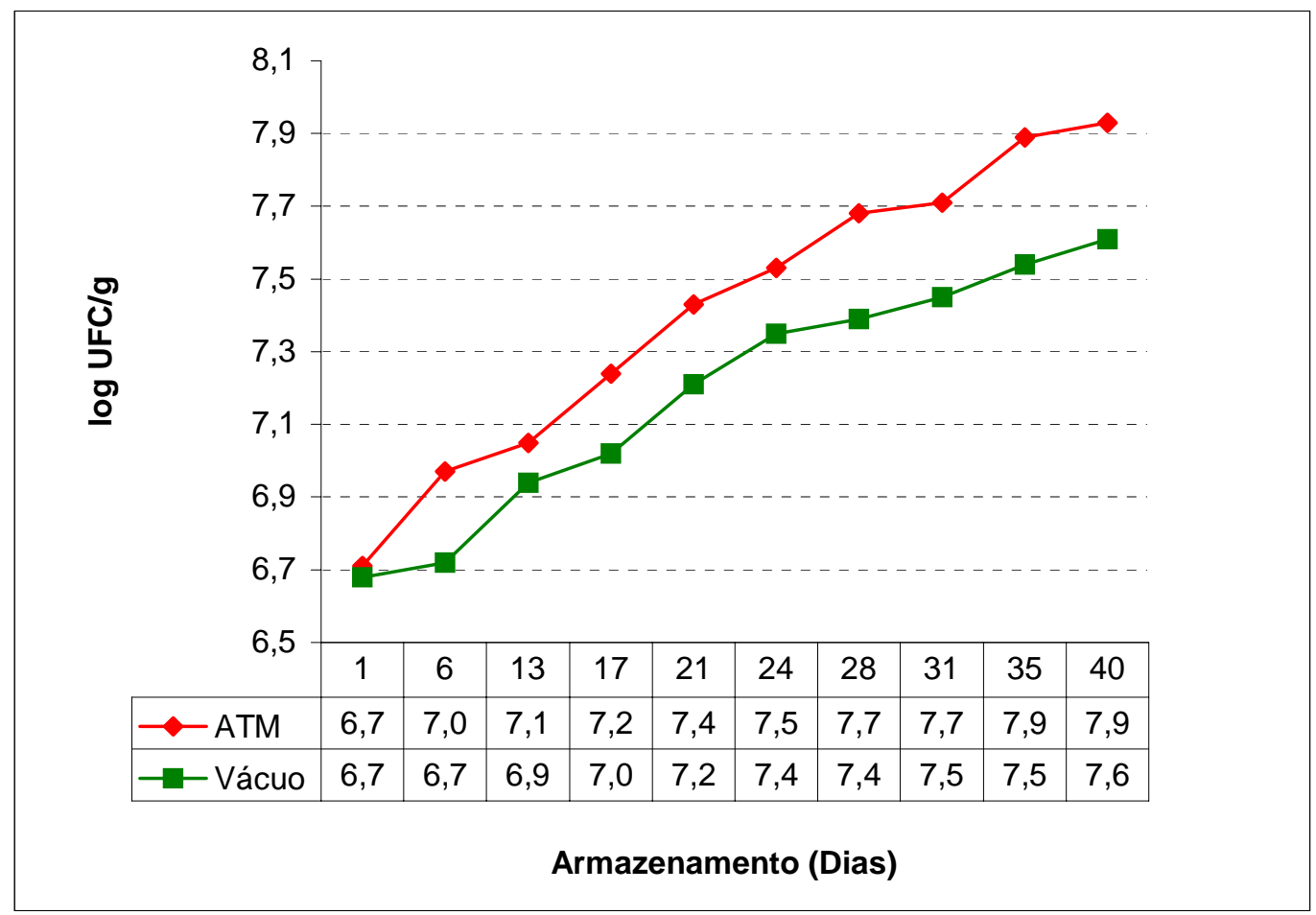

Figura 8 - Evolução da população de psicrotróficos anaeróbios em queijos Minas Frescal embalados a Vácuo e atmosfera modificada (ATM: $70 \% \mathrm{CO}_{2} / 30 \% \mathrm{~N}_{2}$ ) durante o armazenamento a $4^{\circ} \mathrm{C}$.

\subsubsection{Evolução da população de Staphylococcus coagulase positiva}

A Figura 9 mostra os resultados obtidos para Staphylococcus coagulase positiva durante a estocagem do queijo Minas Frescal nos três tratamentos. Verificou-se que no Controle a população permaneceu estável nos 17 dias de armazenamento, no Vácuo ficou estável até o $13^{\circ}$ dia, reduzindo-se então de 3,5 para $3 \log U F C / g$ no $17^{\circ}$ dia, ficando assim até no $31^{\circ}$ dia e declinando mais uma vez para $2,5 \log U F C / g$ no $35^{\circ}$ dia, não se alterando até o final da estocagem. No tratamento com ATM a população desta bactéria de 3,5 log de 
UFC/g ficou estável até o $21^{\circ}$ dia, após houve declínio para 3 log UFC/g e manteve-se estável até $40^{\circ}$ dia.

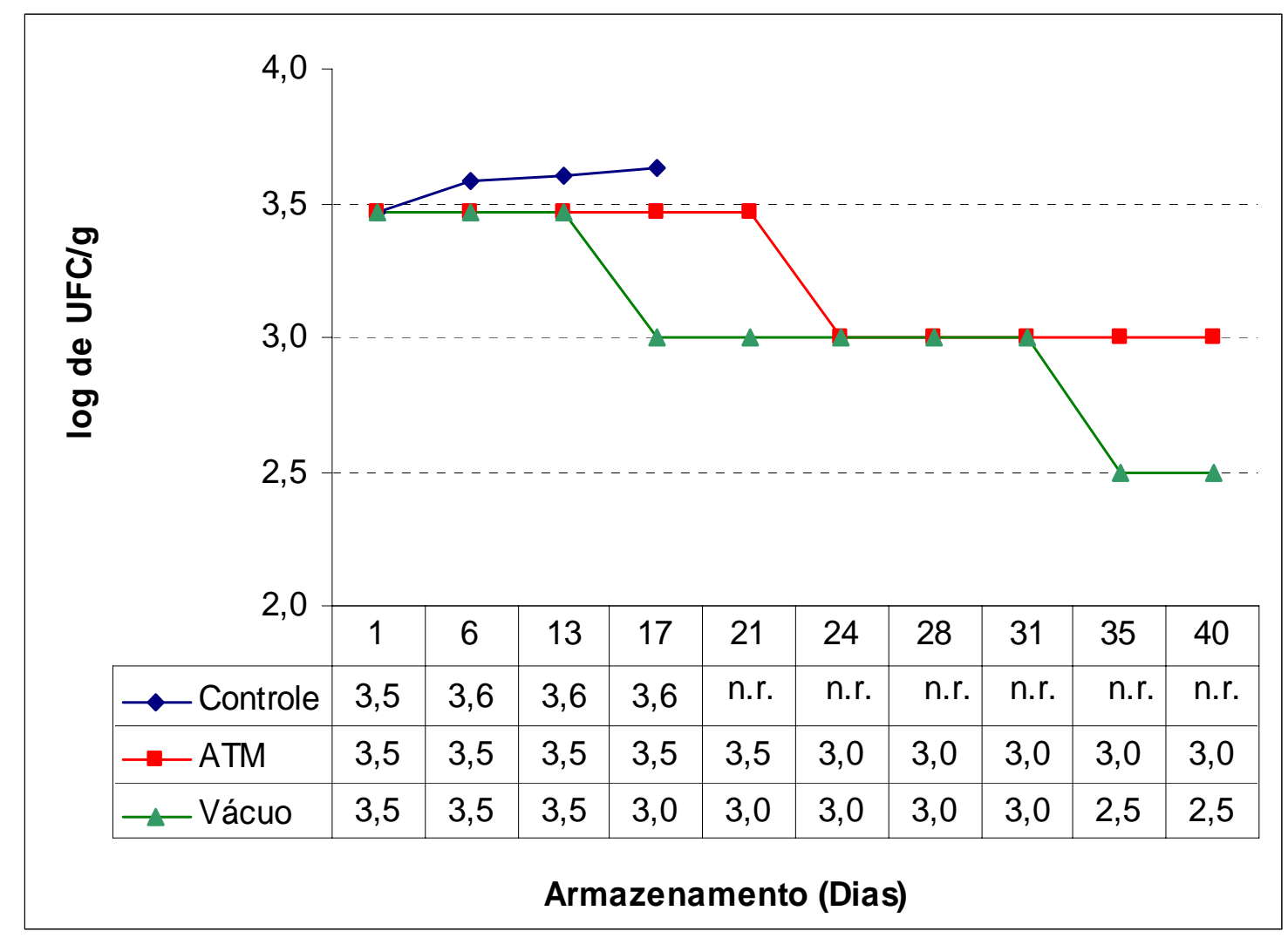

Figura 9 - Evolução da população de Staphylococcus coagulase positiva em queijos Minas Frescal embalados sob ar atmosférico (Controle), Vácuo e atmosfera modificada (ATM: $70 \% \mathrm{CO}_{2} / 30 \% \mathrm{~N}_{2}$ ) durante o armazenamento a $4^{\circ} \mathrm{C}$.

n.r.: análise não realizada.

No trabalho de Eliot et al. (1998), estudou-se o comportamento de Staphylococcus em queijo Mussarela sob diversas atmosferas. Na ATM 75\% de $\mathrm{CO}_{2}$ e $25 \% \mathrm{~N}_{2}$, eles verificaram que a contagem inicial de 1 log de UFC/g e 
foi reduzindo até a quarta semana, não sendo mais detectada. Sob Vácuo ocorreu o mesmo comportamento durante só que em três semanas de armazenamento, concordando com os resultados obtidos no presente trabalho em que tratamento a Vácuo foi mais efetivo.

Faber et al. (1990) analisaram vários tipos de sanduíches sob atmosfera modificada, dentre estes, sanduíche de atum com queijo sob ATM de $70 \%$ de $\mathrm{CO}_{2}$ e $30 \% \mathrm{~N}_{2}$, e verificaram uma redução da população inicial de $S$. aureus que era de $3,1 \times 10^{3} \mathrm{UFC} / \mathrm{g}$ para $<25 \mathrm{UFC} / \mathrm{g}$ após 30 dias de estocagem.

Esse decréscimo da população do gênero Staphylococcus também foi observado em outros trabalhos com queijos sob atmosfera modificada. (Kosikowski \& Brown, 1973; Faber, 1990). Assim, o Staphylococcus parece ser sensível a este tratamento.

Neste estudo, os tratamentos utilizados (Vácuo e ATM) inibiram o desenvolvimento desta bactéria, em que o Vácuo causou uma redução maior durante a estocagem. Já no produto embalado sob ar atmosférico não se verificou nenhuma inibição, mas ao contrário de outras bactérias estudadas, não houve multiplicação.

\subsubsection{Evolução da população de coliformes totais}

Os resultados das contagens de coliformes totais (CT) estão expostos na Figura 10. Verifica-se que os tratamentos não foram eficazes na inibição destes microrganismos, possibilitando o seu crescimento em todos eles, mesmo sob refrigeração. A população de CT inicial foi de 4,3 log NMP/g e, no Controle, atingiu 7,0 log NMP em 17 dias, quando foram suspensas as análises. No tratamento com ATM, a população destes microrganismos proliferou até o $21^{\circ}$ dia, atingindo contagens de 6,4 log NMP/g, seguindo-se então uma fase de declínio contínuo até o final do armazenamento, quando a população atingiu 3,8 log NMP/g. Para o Vácuo, o comportamento foi semelhante, atingindo uma 
contagem de $6,9 \log \mathrm{NMP} / \mathrm{g}$ no $21^{\circ}$ dia, declinando a partir daí e atingindo a contagem de $3,4 \log \mathrm{NMP} / \mathrm{g}$ no $40^{\circ}$ dia de estocagem.

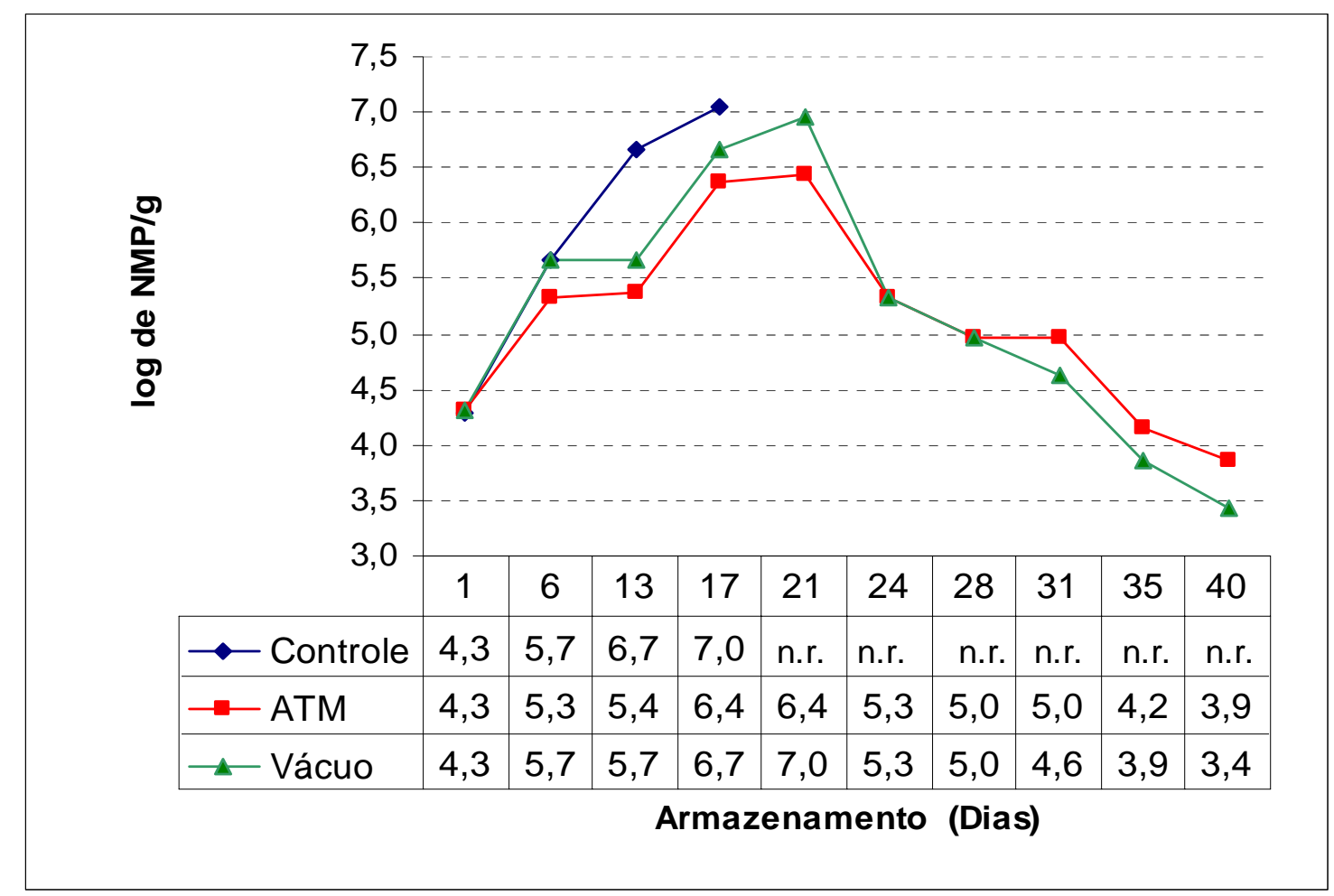

Figura 10 - Evolução da população coliformes totais em queijos Minas Frescal embalados sob ar atmosférico (Controle), Vácuo e atmosfera modificada (ATM: $70 \% \mathrm{CO}_{2} / 30 \% \mathrm{~N}_{2}$ ) durante o armazenamento.

n.r.: análise não realizada.

Também foi observado por Fandos et al. (2000) um crescimento contínuo destes microrganismos durante um período de 30 dias em queijos embalados a Vácuo, em que a população inicial foi menor que 1 log UFC/g e a final ficou superior a 4 log de UFC/g. No presente estudo, contudo, o crescimento ocorreu por 21 dias, seguido depois por uma de fase declínio. Os tratamentos não foram eficazes para esta população, pois ela cresceu continuamente até o $21^{\circ}$ dia, pois o meio de anaerobiose permitiu o seu desenvolvimento. 


\subsubsection{Evolução da população de Escherichia coli}

Os resultados obtidos com Escherichia coli estão representados na Figura 11, foram similares ao comportamento dos coliformes totais, embora o crescimento tenha sido um pouco menor, onde as contagens iniciais de 3,3 log de UFC/g aumentaram até $21^{\circ}$ dia de armazenamento para 4,8 log de UFC/g tanto para ATM como Vácuo, após houve declínio até o final do armazenamento. Também para este microrganismo, os tratamentos utilizados não foram eficazes, permitindo o um crescimento desta população, durante a metade inicial da estocagem.

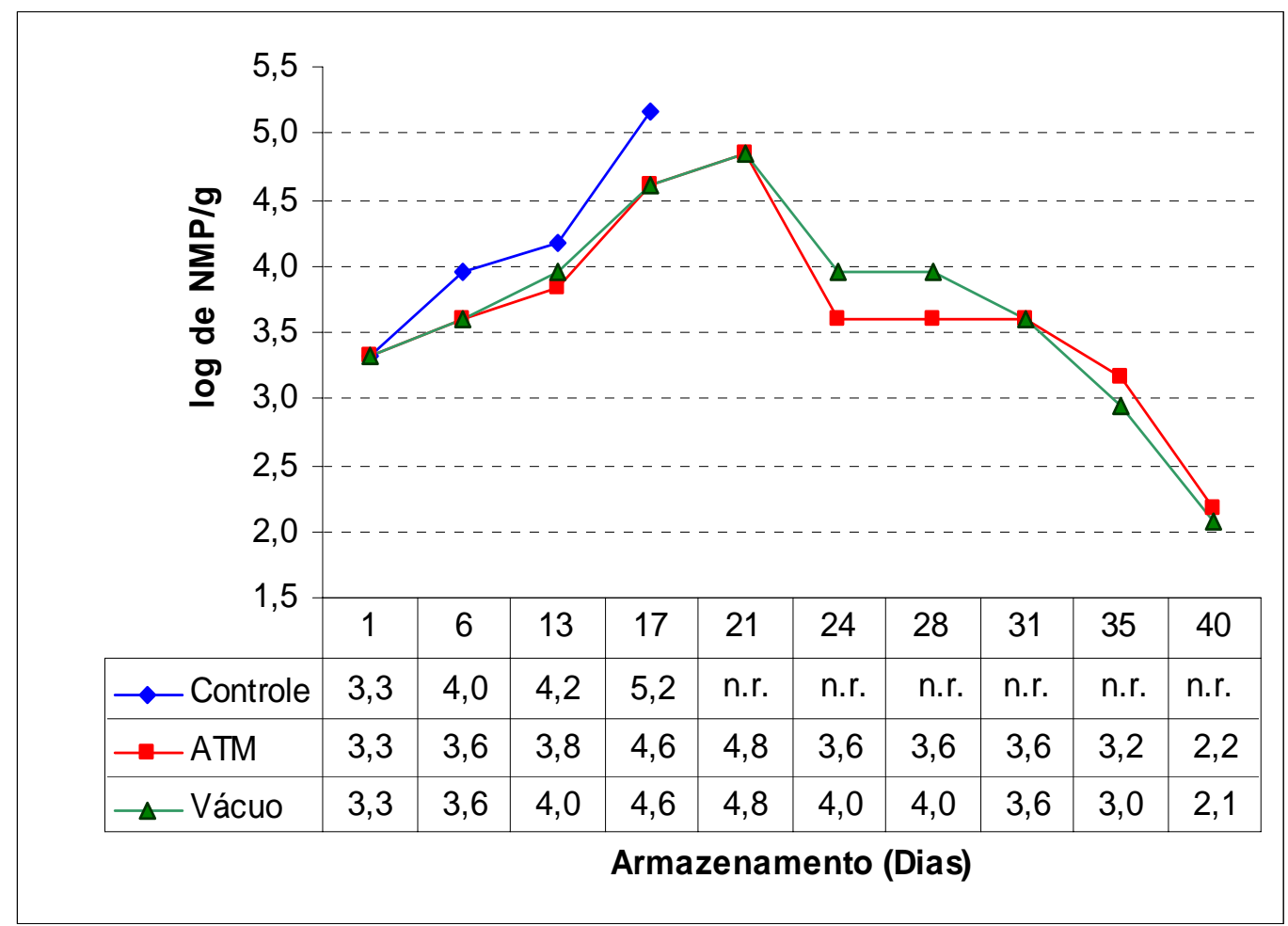

Figura 11 - Evolução da população Escherichia coli em queijos Minas Frescal embalados sob ar atmosférico (Controle), Vácuo e atmosfera modificada (ATM) durante o armazenamento a $4^{\circ} \mathrm{C}$.

n.r.: análise não realizada. 
Assim, conclui-se, a partir dos resultados no presente estudo, que os tratamentos utilizados ATM e Vácuo estabilizaram a população de mesófilos aeróbios e psicrotróficos e reduziram a população de Staphylococcus coagulase positiva, já para a população de coliformes totais e E. coli estes tratamentos não impediram o desenvolvimento destas bactérias.

\subsubsection{Qualidade da matéria-prima utilizada no experimento com atmosfera modificada e irradiação}

$\mathrm{Na}$ Tabela 2 constam os resultados microbiológicos obtidos do queijo Minas Frescal adquirido para o experimento com atmosfera modificada e irradiação. Este produto também não apresentou boa qualidade microbiológica, confirmando que este tipo de produto é bastante problemático.

Tabela 2. Resultado da contagem microbiana inicial do queijo Minas Frescal.

\begin{tabular}{lc}
\hline \multicolumn{1}{c}{ Microrganismos } & Valores \\
\hline Bactérias mesófilas aeróbias (log UFC/g) & 7,25 \\
Bactérias psicrotróficas aeróbias (log UFC/g) & 7,09 \\
Bactérias psicrotróficas anaeróbias (log UFC/g) & 6,54 \\
Coliformes totais (log NMP/g) & 5,84 \\
Escherichia coli (log NMP/g) & 4,32 \\
Staphylococcus coagulase positiva (log UFC/g) & 3,20 \\
\hline
\end{tabular}

As contagens de Staphylococcus coagulase positiva e Escherichia coli foram de 3,2 e 4,2 log de UFC/g, respectivamente (Tabela 2), sendo superiores aos limite estabelecidos pela legislação (2,6 log de UFC/g para Staphylococcus coagulase positiva e 2,6 NMP/g para coliformes a $45^{\circ} \mathrm{C}$ ). Esta contaminação ocorreu provavelmente devido à falta de condições higiênicas e manipulação inadequada do produto durante o processamento, conforme discutido em 4.1.1. 
Neste caso, também não foi possível processar o produto, pois não havia condições de infra-estrutura para a quantidade de queijo necessária $(35 \mathrm{Kg}$ ) para o experimento, e não foi possível retornar o produto para a indústria pois quando os resultados ficaram prontos, os processos de embalagem e irradiação já haviam sido realizados. Contudo, já havia sido prevista essa eventualidade e, exatamente por isso, foi adicionado o tratamento por irradiação. Para este estudo, inclusive, era desejável um produto com elevada contaminação.

Os produtos adquiridos para a realização das duas partes do experimento mostram a real qualidade microbiológica na qual a maioria dos queijos Minas Frescal se encontram no mercado. Isso pode ser confirmado por outros pesquisadores, os quais encontraram este produto fora da legislação (Colen et al., 1984; Pereira et al., 1987; Raimund, 1992; Souza et al., 1993; Silva et al. 1993; Laicini et al., 1993; Santos et al., 1995; Dias et al., 1995; Rodrigues et al., 1995; Carmo et al. 1995; Gomes \& Gallo, 1995; Carvalho et al., 1996; Oliveira et al., 1998; Leite et al., 2000 e Silva et al., 2001).

\subsubsection{Efeito da irradiação sobre população microbiana nos queijos embalados sob ar atmosférico, ATM e Vácuo}

\subsubsection{Contagem de mesófilos aeróbios totais}

$\mathrm{Na}$ Figura 12 pode-se verificar que a população de microrganismos mesófilos aeróbios totais no queijo Minas Frescal não irradiado foi de 7,2 log de UFC/g e, após a irradiação, com doses de 2KGy, a população sofreu uma redução de 1,6 log de UFC/g para o produto embalado sob ar atmosférico (Controle), de 0,8 log de UFC/g para o produto embalado sob ATM e de 0,3 log de UFC/g para o Vácuo. Assim, as contagens, após a irradiação, foram de 5,6 log de UFC/g para o Controle, 6,4 log de UFC/g para o ATM e 6,9 log de UFC/g para o Vácuo. 


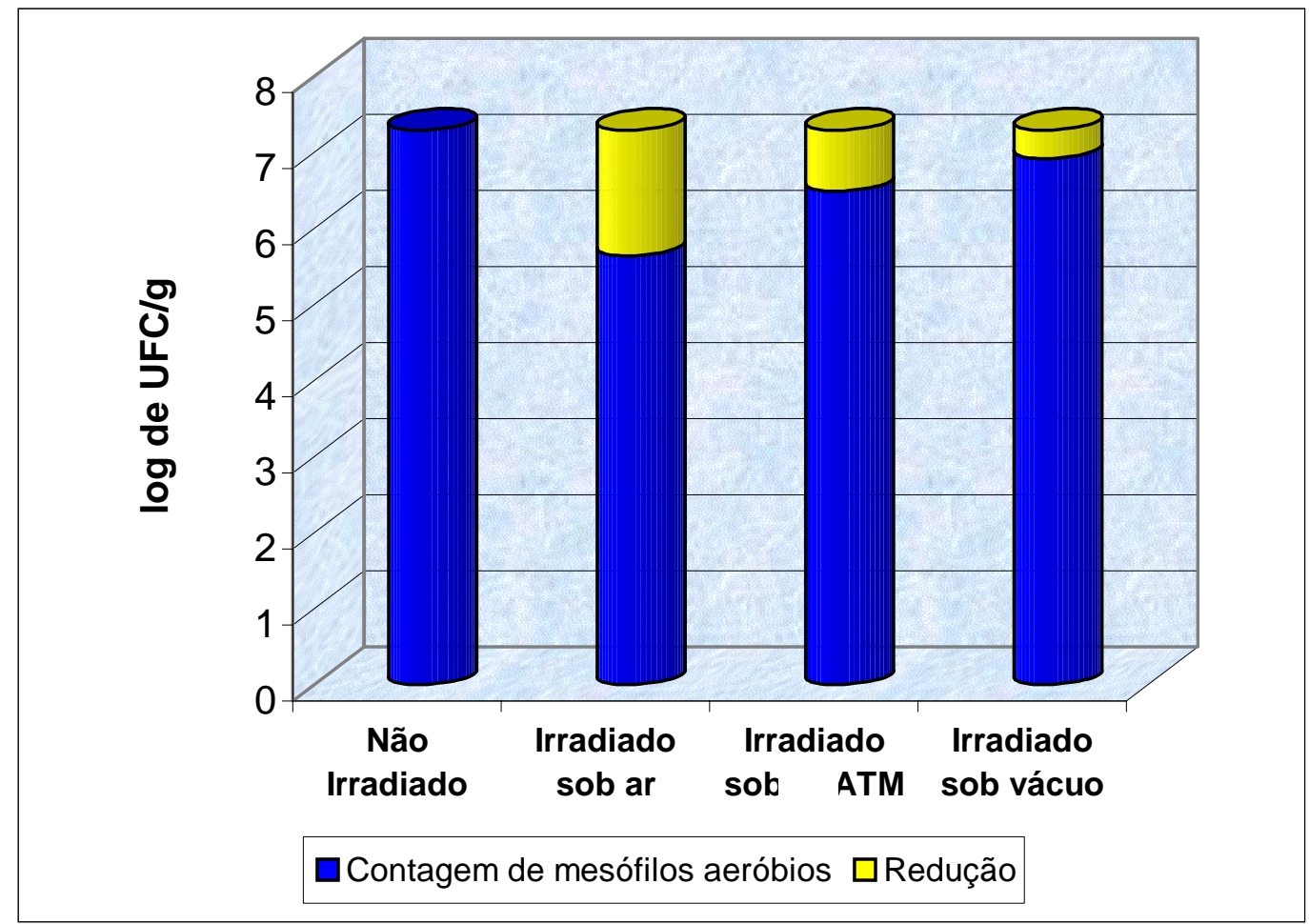

Figura 12 - Contagem de microrganismos mesófilos aeróbios totais em queijos Minas Frescal não irradiados e irradiados com 2 KGy embalados sob ar atmosférico (Controle), atmosfera modificada (ATM: $70 \% \mathrm{CO}_{2} / 30 \% \mathrm{~N}_{2}$ ) e Vácuo.

No trabalho realizado por Ibrahim et al (1987), também houve uma redução na contagem de mesófilos aeróbios totais em queijo Rãs, em que a população inicial de 6,7 log de UFC/g para os queijos não irradiados diminui para 6,1 log de UFC/g após a irradiação com 2,5 KG. Assim houve uma pequena redução de $0,6 \log$ de UFC/g, a qual foi encontrada em valores similares no queijo sob ATM e Vácuo deste estudo.

Foi observado, uma redução de três ciclos logarítmicos na contagem total mesófilos aeróbios por Ewis et al. (1989), no queijo Roquefort irradiado 
com dose de 2,5 KG. Esta redução foi maior do que a encontrada no presente trabalho. Isto é justificado pelo uso de uma dose maior de irradiação.

Gutierrez (2000) verificou que, utilizando dose de 2 KGy, houve uma diminuição de 2 ciclos logarítmicos na população de mesófilos aeróbios em queijo Prato. Tal redução foi similar ao encontrado no Controle (1,6 ciclos logarítmicos) do presente trabalho.

Hashisaka et al. (1990) estudaram o efeito de diferentes doses de irradiação na população de mesófilos aeróbios em queijo Cheddar, queijo Mussarela e sorvete de creme. Verificaram uma redução de 2 ciclos logarítmicos no queijo Cheddar irradiado com 5 KGy; para o queijo Mussarela irradiado com 5 KGy foi verificada uma redução de 4 ciclos logarítmicos e no sorvete de creme irradiado com 5 KGy observaram uma redução de 3 ciclos logarítmicos. Para todos estes produtos eles observaram uma redução maior do que a encontrada no presente trabalho. Isto ocorreu, certamente, pela maior dose de irradiação utilizada.

\subsubsection{Contagem de psicrotróficos aeróbios totais}

$\mathrm{Na}$ Figura 13 estão os resultados obtidos nas contagens de microrganismos psicrotróficos aeróbios totais em queijos Minas Frescal não irradiados e irradiados com 2 KGy nos três tratamentos (Controle, ATM e Vácuo). Na figura, verifica-se que a população inicial do queijo antes da irradiação foi de 7 log de UFC/g e, após a irradiação, houve uma redução de 2,1 ciclos logarítmicos no Controle, de 1,5 ciclo logarítmico para o ATM e 1,4 ciclo logarítmico para o Vácuo. Assim, as contagens finais foram de 4,9 log de UFC/g para Controle, 5,5 log de UFC/g para ATM e 5,6 log de UFC/g para o queijo embalado sob Vácuo. 


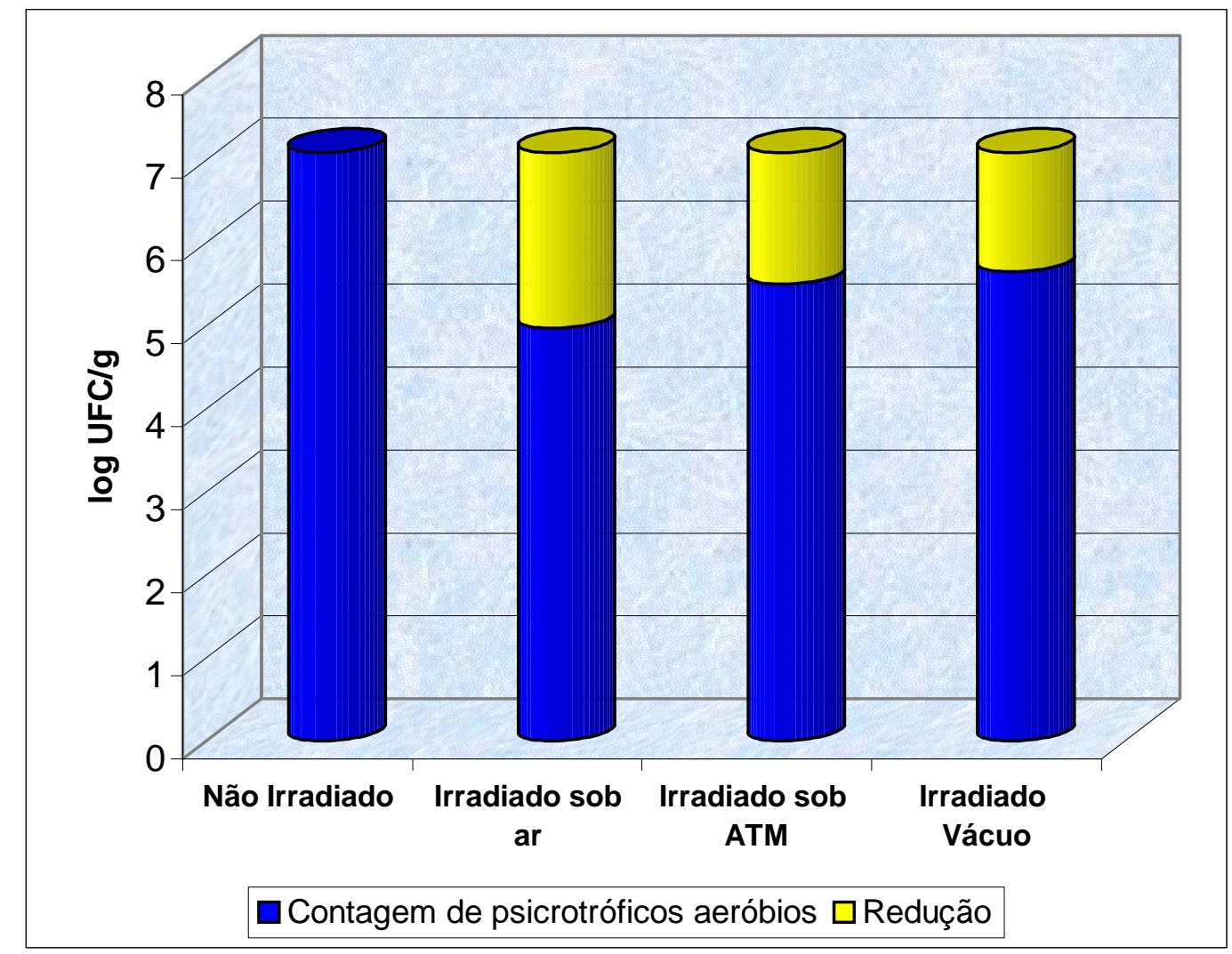

Figura 13 - Contagem de microrganismos psicrotróficos aeróbios totais em queijos Minas Frescal não irradiados e irradiados com 2 KGy embalados sob ar atmosférico (Controle), atmosfera modificada (ATM: $70 \% \mathrm{CO}_{2} / 30 \% \mathrm{~N}_{2}$ ) e Vácuo.

Muitos diferentes gêneros e espécies de microrganismos podem estar presentes na população de psicrotróficos, os quais são largamente distribuídos na natureza. São um grupo numeroso de microrganismos e incluem bactérias na forma de bastonetes, cocos e vibriões, formas esporuladas e não esporuladas, Gram negativas e Gram positivas, aeróbios anaeróbios facultativos e anaeróbios. Predominam nesse grupo as bactérias Gram negativas como Pseudomonas, Flavobacterium, Alcaligenes, Alteromonas e 
outras. Dentre as Gram positivas podem ser citadas Bacillus, Micrococus e outros (Cousin et al. 1992).

Hashisaka et al. (1990) estudaram o efeito de diferentes doses de irradiação na população de psicrotróficos aeróbios em queijo Cheddar e sorvete de creme. Eles verificaram que no queijo Cheddar irradiado com $5 \mathrm{KGy}$, houve uma redução de 3 ciclos logarítmicos e no sorvete de creme irradiado com doses de 5 KGy houve uma redução de 2 ciclos logarítmicos. Assim, podese verificar que a redução foi similar à encontrada no presente trabalho, mesmo com uma dose menor (2KGy).

\subsubsection{Contagem de psicrotróficos anaeróbios totais}

$\mathrm{Na}$ Figura 14 estão os resultados obtidos na contagem de microrganismos psicrotróficos anaeróbios totais em queijos Minas Frescal não irradiados e irradiados com 2 KGy sob ar atmosférico, ATM e Vácuo. Observando-se a figura, verifica-se que a população inicial do queijo, antes da irradiação, foi de 6,2 log de UFC/g e foi reduzida para 4,5 log de UFC/g para o queijo embalado sob ATM e para 4,6 log de UFC/g para o queijo embalado sob Vácuo. 


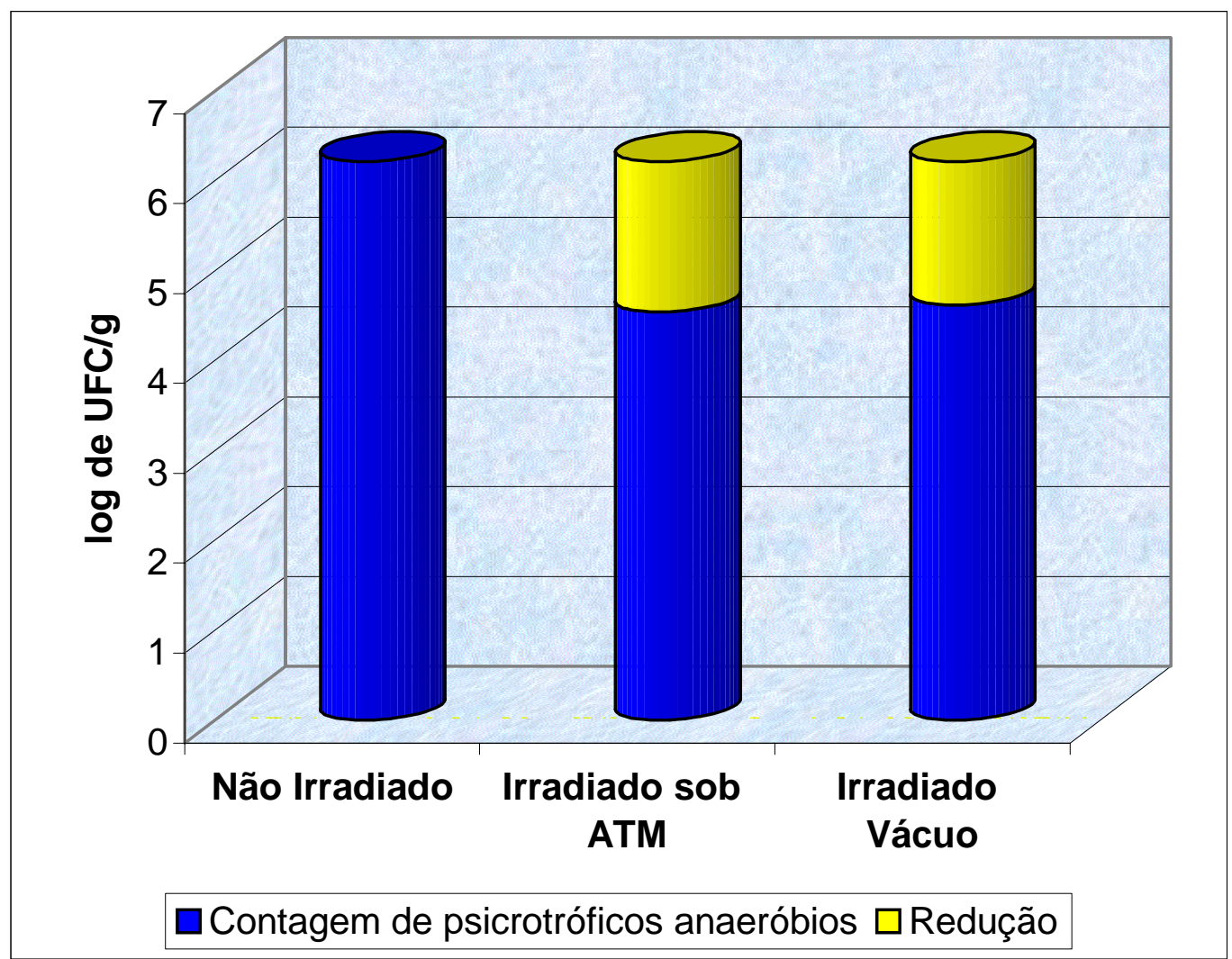

Figura 14 - Contagem de microrganismos psicrotróficos anaeróbios totais em queijos Minas Frescal não irradiados e irradiados com 2 KGy embalados sob atmosfera modificada (ATM: $70 \% \mathrm{CO}_{2} / 30 \% \mathrm{~N}_{2}$ ) e Vácuo.

\subsubsection{Contagem de Staphylococcus coagulase positiva}

$\mathrm{Na}$ Figura 15 estão os resultados obtidos na contagem de Staphylococcus nos diferentes tratamentos utilizados e no testemunho inicial. Observando-se a figura, verifica-se que a população inicial do queijo antes da irradiação foi de 3,2 log de UFC/g e, após a irradiação, constatou-se ausência de Staphylococcus coagulase positiva em todas as amostras analisadas e em 
todos os tratamentos utilizados. Portanto, a dose utilizada foi muito eficiente sobre estes microrganismos.

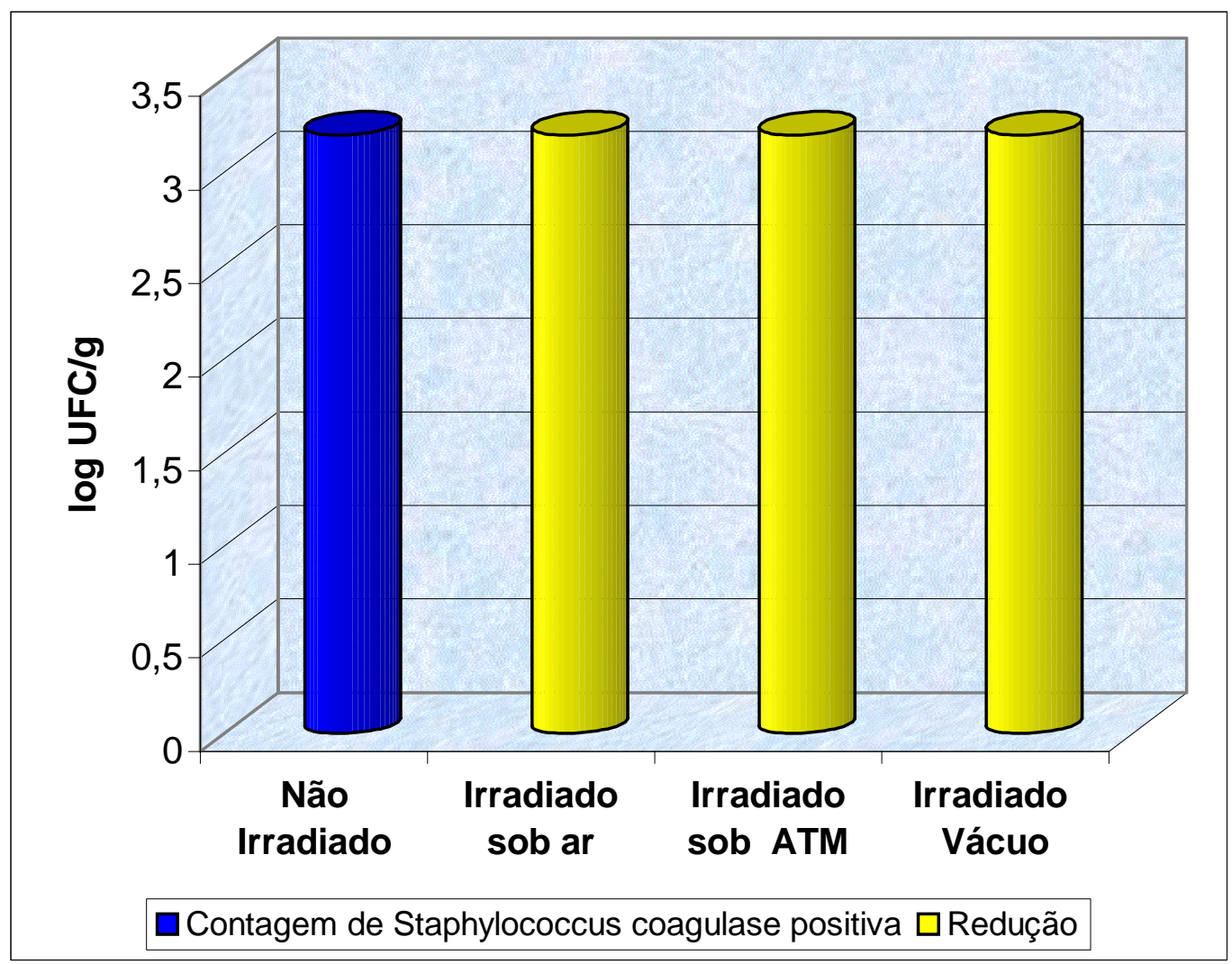

Figura 15 - Contagem de Staphylococcus coagulase positiva em queijos Minas Frescal não irradiados e irradiados com 2 KGy embalados sob ar atmosférico (Controle), atmosfera modificada (ATM: $70 \% \mathrm{CO}_{2} / 30 \% \mathrm{~N}_{2}$ ) e Vácuo.

A redução nos três tratamentos foi a mesma, concordando com Patterson (1988), que demonstrou que o S. aureus não apresenta alteração quanto a sua sensibilidade à irradiação por raios gama sob diferentes atmosferas (oxigênio, nitrogênio, gás carbônico, Vácuo e nitrogênio). 
Os resultados de sobrevivência de Staphylococcus coagulase positiva concordam com Monk et al. (1995), que afirmam que doses de 2 KGy são suficientes para inativar este patógeno. A dose utilizada neste experimento (2KGy) mostrou-se eficiente para a redução de três ciclos logarítmicos na contagem de Staphylococcus.

Gurgel (2000) estudou o comportamento de S. aureus inoculado em queijo Minas Frescal com diferentes doses de irradiação e verificou que a dose de 2 KGy apresentou diminuição significativa (3 ciclos logarítmicos) na contagem desta bactéria, podendo ser considerada eficiente.

\subsubsection{Contagem de coliformes totais}

$\mathrm{Na}$ Figura 16 estão os resultados obtidos na contagem de microrganismos coliformes totais em queijos Minas Frescal não irradiados e irradiados com $2 \mathrm{KGy}$ sob diferentes tratamentos (Controle, ATM e Vácuo). Na figura observa-se que a população inicial do queijo, antes da irradiação, foi de 5,8 log de UFC/g e, após a irradiação, reduziu-se para $<0,3 \mathrm{UFC/g}$ no queijo embalado sob ar atmosférico, 2,3 log de UFC/g para o queijo embalado sob ATM e 1,4 log de UFC/g para o queijo embalado sob Vácuo, havendo uma redução de 5,8; 3,52; e 4,4 (log de UFC/g), respectivamente para o Controle, ATM e Vácuo. 


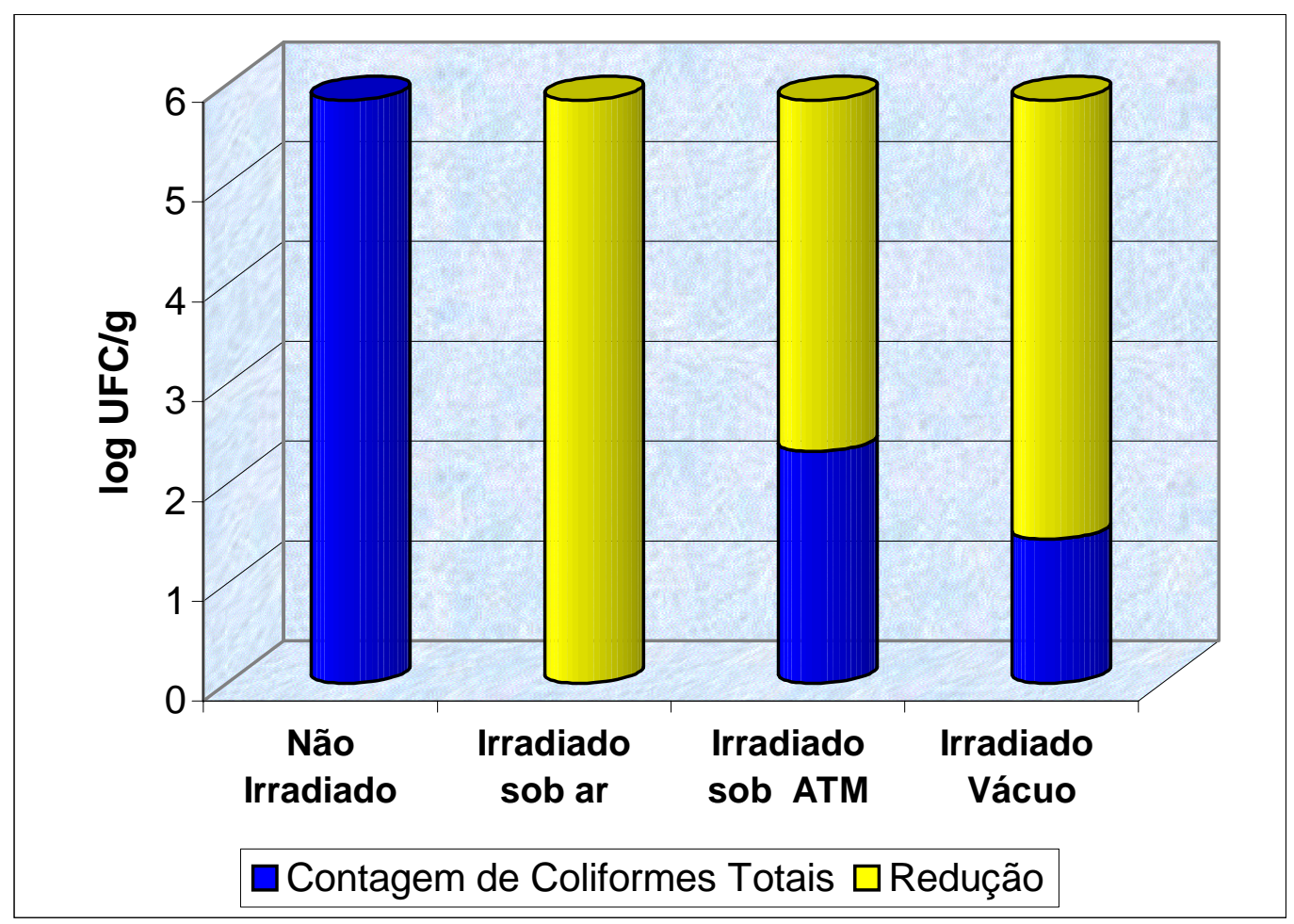

Figura 16 - Contagem coliformes totais em queijos Minas Frescal não irradiados e irradiados com 2 KGy embalados sob ar atmosférico (Controle), atmosfera modificada (ATM: $70 \% \mathrm{CO}_{2} / 30 \% \mathrm{~N}_{2}$ ) e Vácuo.

\subsubsection{Contagem de Escherichia coli}

Na Figura 17 estão os resultados obtidos na contagem de Escherichia coli em queijos Minas Frescal não irradiados e irradiados com 2 KGy embalados sob ar atmosférico (Controle), ATM e Vácuo. Na figura, verifica-se que a população inicial do queijo, antes da irradiação, foi de 4,32 log de UFC/g, reduziu para $<3 \mathrm{UFC/g}$ no Controle, 1,87 log de UFC/g no ATM e 0,84 log de UFC/g no Vácuo, havendo uma redução de 4,32 ciclos logarítmicos para o Controle, 2,45 ciclos logarítmicos para o ATM e 3,48 ciclos logarítmicos para o Vácuo. 


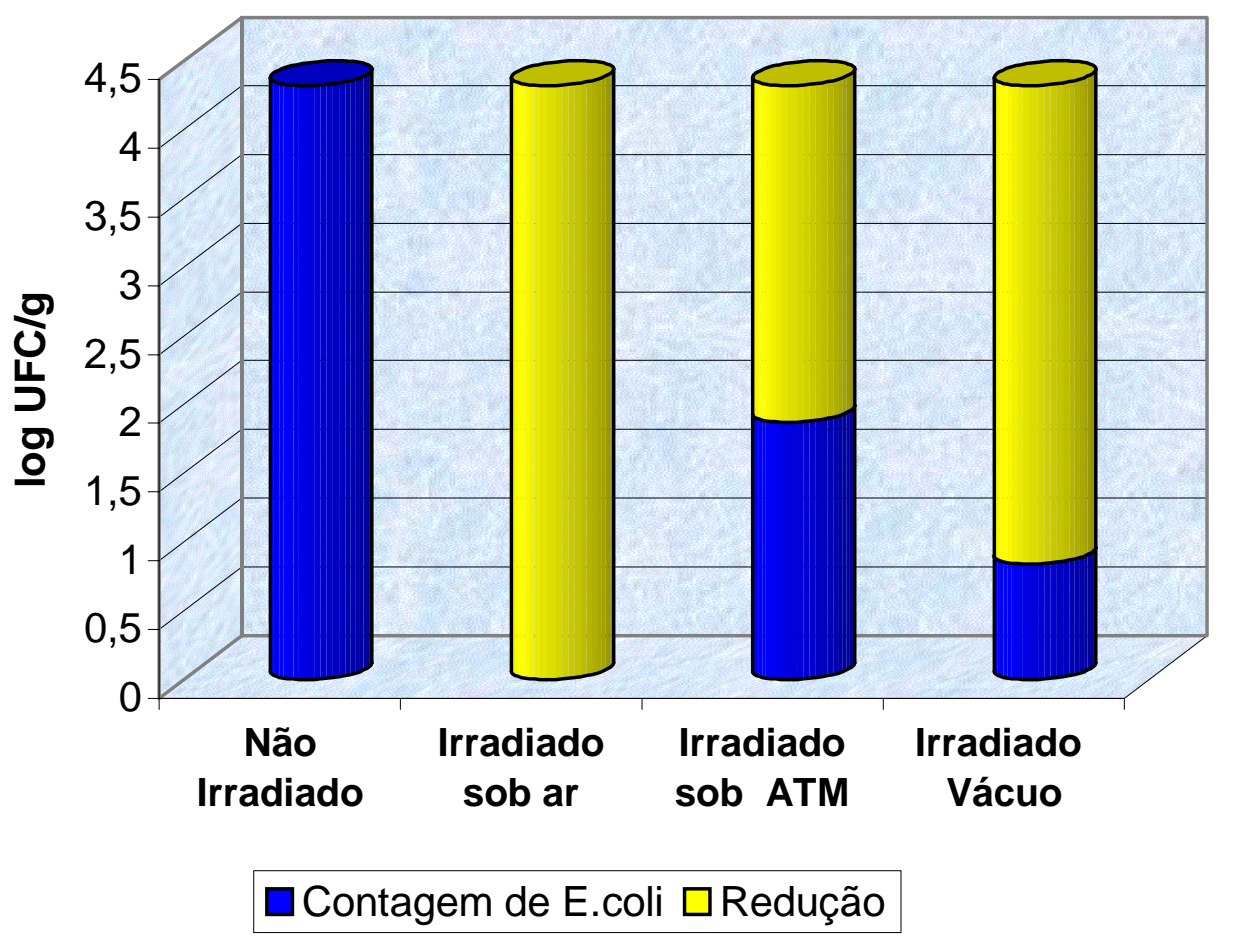

Figura 17 - Contagem de Escherichia coli em queijos Minas Frescal não irradiados e irradiados com $2 \mathrm{KGy}$ sob ar atmosférico (Controle), atmosfera modificada (ATM: $70 \% \mathrm{CO}_{2} / 30 \% \mathrm{~N}_{2}$ ) e Vácuo.

Em todos os microrganismos, como se observa nas Figuras 12, 13, 14, 15, 16 e 17 houve sempre uma maior redução da população microbiana no tratamento sob ar atmosférico do que sob ATM e Vácuo. Isto pode ser explicado em função do stress oxidativo, após passar pelo tratamento de irradiação. O efeito oxidativo tem sido atribuído principalmente ao radical hidroxil $\left(\mathrm{OH}^{-}\right)$, o qual tem sido reconhecido como o radical de potencial mais perigoso em meio de produtos radiolíticos primários em água. O radical hidroxil é conhecido por atacar moléculas estruturais e funcionais existentes nas células, produzindo um grande número de reações biológicas. Além de danificar o DNA e a membrana citoplasmática (a danificação oxidativa das membranas pode ser originária de outros lipídios ou de danificações das membranas 
protéicas), podendo ocasionar a morte das células, os radicais de oxigênio também danificam as células e as proteínas. Essa lesão desgasta a energia e a reserva da célula, podendo a molécula da célula ficar em outro estado energético ou degenerada. Além disso, isto pode ser transmitido para as células microbianas através de um moderado stress oxidativo, irradiação e subseqüente estocagem na presença de oxigênio, aumentando a velocidade da oxidação lipídica (Thakur \& Singh, 1996).

No trabalho realizado por Stecchini et al (1995), em que foi inoculada Aeromonas hydrophila em carne de frango, embalada a Vácuo e irradiada com doses de 1KGy, também verificaram uma redução maior para o produto sob ar atmosférico, em que a população inicial de 7,5 log de UFC/g houve redução total sob ar e o produto embalado sob Vácuo reduziu para 1,11 log de UFC/g.

Farkas (1998) relatou no seu trabalho que o valor $D_{10}$ para produtos em atmosfera modificada e Vácuo é maior em relação ao dos produtos sob ar atmosférico. Pode-se citar como exemplo a bactéria Campylobacter jejuni cujo valor $D_{10}$ é de 0,10 KGy para produtos sob ar e 0,27 KGy para produtos sob Vácuo. Para Listeria monocytogenes, o valor $\mathrm{D}_{10}$ é de 0,54-0,64 KGy para produtos sob ar e 0,60-0,70 KGy para produtos sob $\mathrm{CO}_{2}: \mathrm{N}_{2}$ (1:3) em carnes de porco. Para Salmonella typhirium o valor $\mathrm{D}_{10}$ é de 0,54-0,64 KGy para produtos sob ar e 0,60-0,70 KGy para produtos sob $\mathrm{CO}_{2}: \mathrm{N}_{2}(1: 3)$ em carnes de porco.

\subsubsection{Comportamento da população microbiana no queijo Minas Frescal sob atmosfera modificada e irradiado}

\subsubsection{Evolução da população de mesófilos aeróbios totais}

Na Figura 18 constam os resultados obtidos na evolução da população dos microrganismos mesófilos aeróbios totais em queijos Minas Frescal irradiados com 2 KGy embalados sob ar atmosférico (Controle), atmosfera 
modificada (ATM: $70 \% \mathrm{CO}_{2} / 30 \% \mathrm{~N}_{2}$ ) e Vácuo durante o armazenamento a $4^{\circ} \mathrm{C}$. Verifica-se que a população, após a irradiação manteve-se estável para o Controle durante os doze dias de armazenamento. Após houve um crescimento contínuo, chegando à contagens de 7,2 log de UFC/g no $21^{\circ}$ dia. Para os queijos sob ATM, a população inicial no $1^{\circ}$ dia de armazenamento, após a irradiação, foi de 6,4 log de UFC/g, a qual se manteve estável até o $19^{\circ}$ dia. A partir desta semana decresceu um ciclo logarítmico até o $47^{\circ}$ dia de armazenamento. Nos queijos embalados sob Vácuo, a população inicial de mesófilos aeróbios de 6,82 log de UFC/g manteve-se estável até o $19^{\circ}$ dia de armazenamento, após também decresceu, atingindo contagem de 6,34 log de UFC/g.

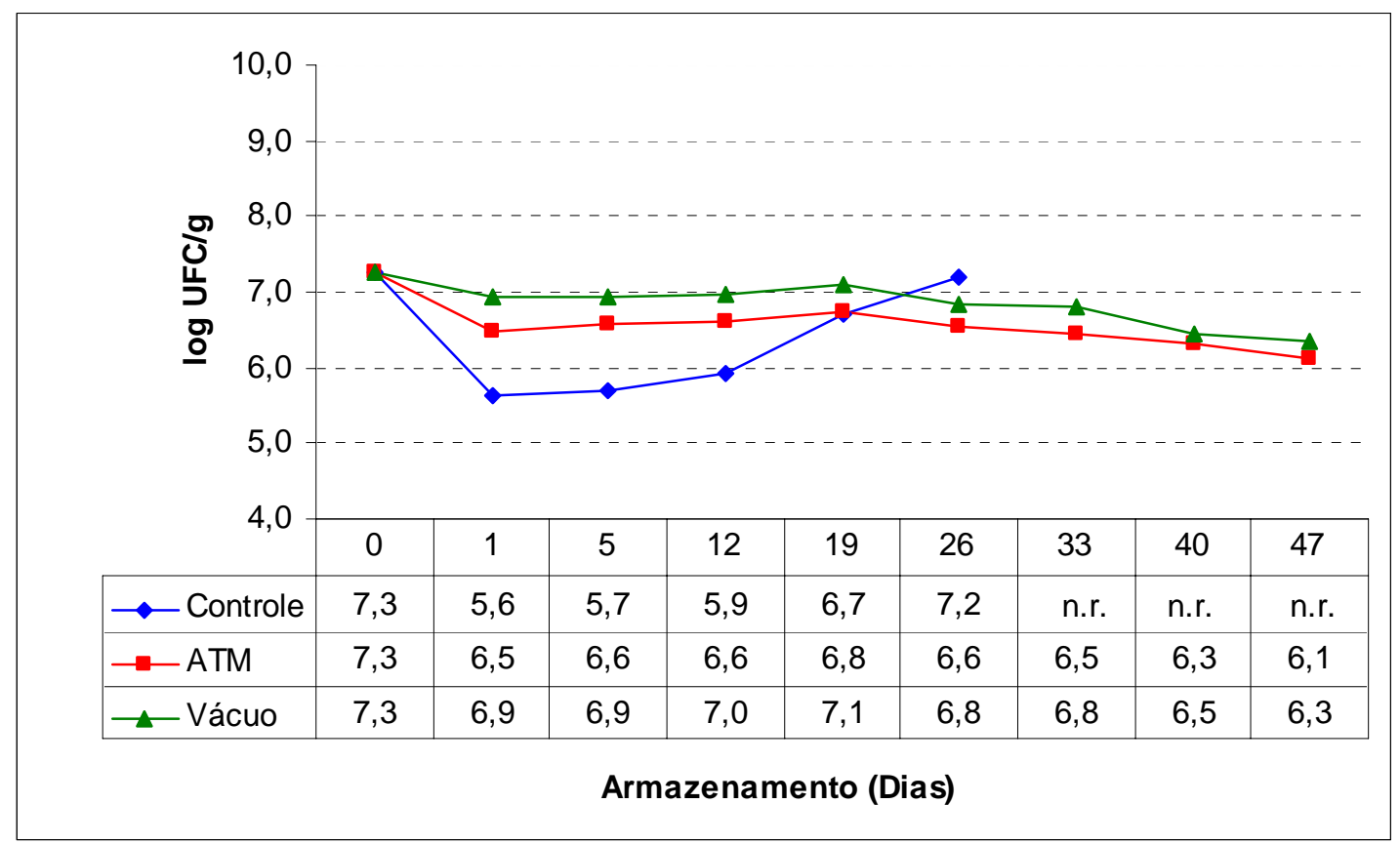

Figura 18 - Evolução da população de microrganismos mesófilos aeróbios totais em queijos Minas Frescal irradiados com 2 KGy embalados sob ar atmosférico (Controle) atmosfera modificada (ATM: $70 \% \mathrm{CO}_{2} / 30 \% \mathrm{~N}_{2}$ ) e Vácuo durante o armazenamento a $4^{\circ} \mathrm{C}$.

n.r.: análise não realizada. 
Assim, pode-se concluir que os tratamentos com atmosfera utilizados inibiram o crescimento deste grupo, pois o Controle (ar), apesar da contaminação após a irradiação ser menor, não conseguiu impedir o desenvolvimento microbiano durante o armazenamento.

Comparando estes resultados com a primeira parte do experimento (Figura 6), verifica-se que a população de mesófilos teve um aumento de 2 ciclos durante os 40 dias de armazenamento para o ATM e Vácuo. Já na segunda parte, em que ocorreu irradiação (Figura 18), não houve o crescimento da população de mesófilos, sendo esta inibida após o tratamento de irradiação. No Controle pôde-se verificar que nos dois tratamentos com e sem irradiação (Figura 6 e 18) houve proliferação de microrganismos aeróbios mesófilos, sendo que no produto irradiado o crescimento foi mais lento. Assim, o menor efeito da irradiação sobre a população microbiana inicialmente nos tratamentos ATM e Vácuo é compensado pela inibição no seu crescimento. Tal efeito pode ser atribuído aos efeitos somados pelas barreiras: temperatura e atmosfera, posteriores ao estress da irradiação.

\subsubsection{Evolução da população de psicrotróficos aeróbios totais}

Na Figura 19 estão os resultados da evolução da população de psicrotróficos aeróbios em queijos Minas Frescal irradiados com 2KGy embalados sob ar atmosférico (Controle), ATM e Vácuo, durante o armazenamento a $4^{\circ} \mathrm{C}$. No Controle, pode ser observado que a população inicial de 4,9 log de UFC/g aumentou dois ciclos logarítmicos durante o armazenamento; a população final ficou em 7,2 log de UFC/g. Nos queijos embalados sob ATM a contagem inicial (5,5 log de UFC/g) teve um pequeno aumento ( 1 ciclo logarítmico) na primeira semana e depois se manteve praticamente estável, crescendo apenas mais 1 ciclo logarítmico durante todo o armazenamento (40 dias), sendo a população final de 7 log de UFC/g. Para os produtos embalados a Vácuo, a população inicial (5,56 log de UFC/g) aumentou 
1 ciclo na primeira semana (6,5 log de UFC/g) de armazenamento e aumentou novamente 1 ciclo até o final do armazenamento.

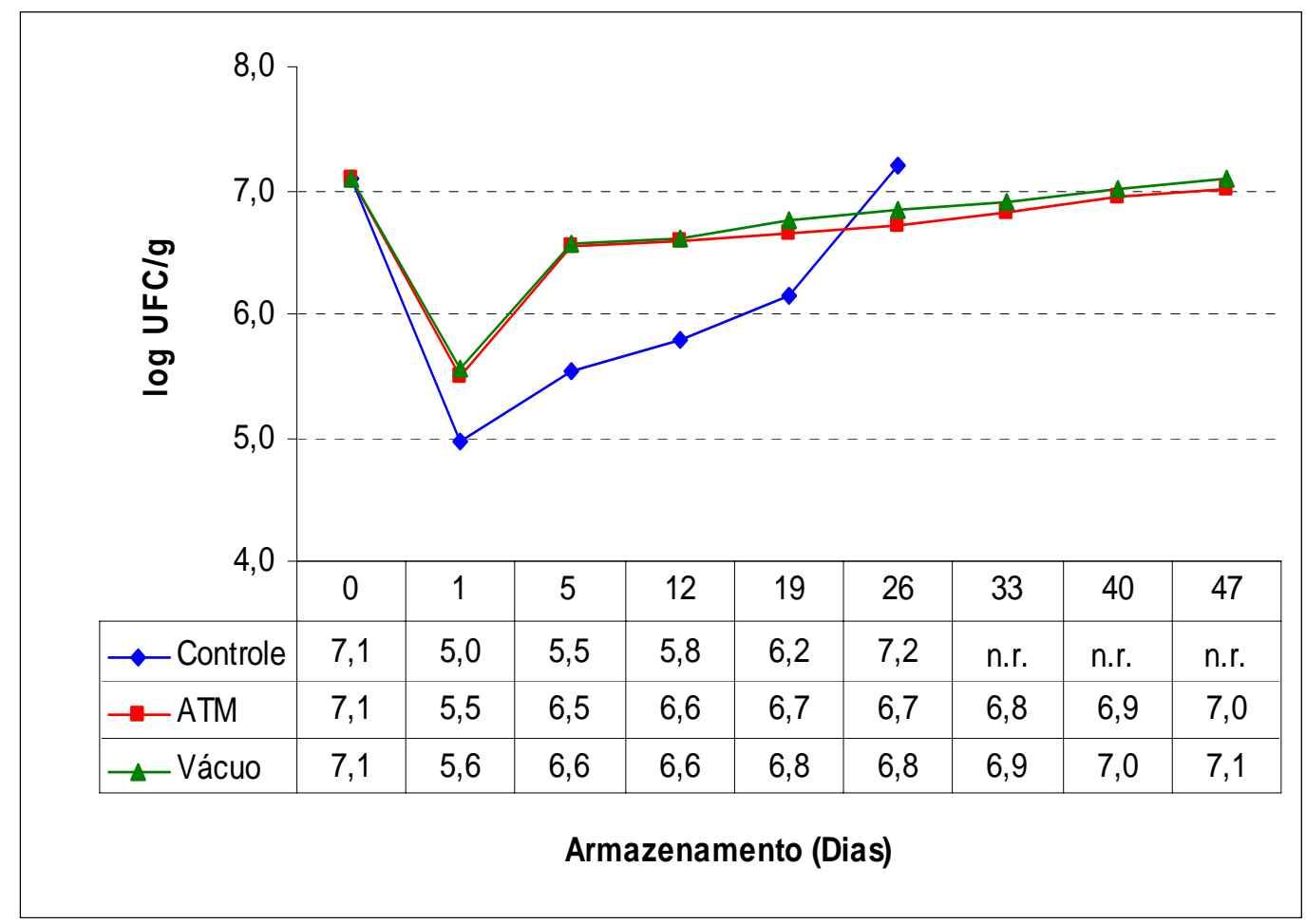

Figura 19 - Evolução da população de psicrotróficos aeróbios em queijos Minas Frescal irradiados com 2KGy embalados sob ar atmosférico (Controle), atmosfera modificada (ATM: $70 \% \mathrm{CO}_{2} / 30 \% \mathrm{~N}_{2}$ ) e Vácuo durante o armazenamento a $4^{\circ} \mathrm{C}$.

n.r: análise não realizada.

Inicialmente, a irradiação foi mais eficaz no Controle na redução da carga microbiana, mas durante o armazenamento esta população aumentou progressivamente superando em 26 dias a contagem inicial antes da irradiação do produto. Já nos tratamentos sob ATM e Vácuo o efeito da irradiação foi 
menor, mas os tratamentos evitaram o crescimento da população durante os 47 dias de armazenamento, conforme se observa na Figura 19.

Assim conclui-se que, após a redução inicial da população de psicrotróficos aeróbios os tratamentos (Vácuo e ATM irradiados) utilizados mantiveram-se estáveis a partir da segunda semana, até os 45 dias de armazenamento, já o Controle permitiu o desenvolvimento contínuo da população de psicrotróficos aeróbios.

Pode-se observar pelas Figuras 7 e 19 que o comportamento dos psicrotróficos aeróbios foi similar nas duas fases do experimento, pois estes tiveram um crescimento na primeira semana de armazenamento. Depois esta população foi inibida nos produtos embalados sob ATM e Vácuo. No Controle, o crescimento desta população não foi inibida tanto nos produtos irradiados como nos não irradiados.

\subsubsection{Evolução da população de psicrotróficos anaeróbios totais}

Na Figura 20 está o gráfico de evolução da população de psicrotróficos anaeróbios em queijo Minas Frescal irradiados com 2 KGy sob ATM e Vácuo durante o armazenamento a $4^{\circ} \mathrm{C}$. A contagem manteve-se praticamente a mesma para os dois tratamentos (ATM e Vácuo), verificando-se que a população inicial de 4,5 log de UFC/g cresceu continuamente aumentando 3 ciclos logarítmicos durante os 47 dias de armazenamento, sendo a população final foi de 7,7 e 7,5 log de UFC/g, respectivamente para ATM e Vácuo. Para esta população os tratamentos não foram eficazes, pois a população cresceu continuamente durante toda o armazenamento. O mesmo ocorreu na primeira parte do experimento (Figura 8), em que esta população não foi contida pela modificação da atmosfera. Ao contrário, da população de psicrotróficos aeróbios, esta categoria que teve condições de se recuperar do estress sofrido, aumentou três ciclos logarítmicos em 45 dias de armazenamento. 


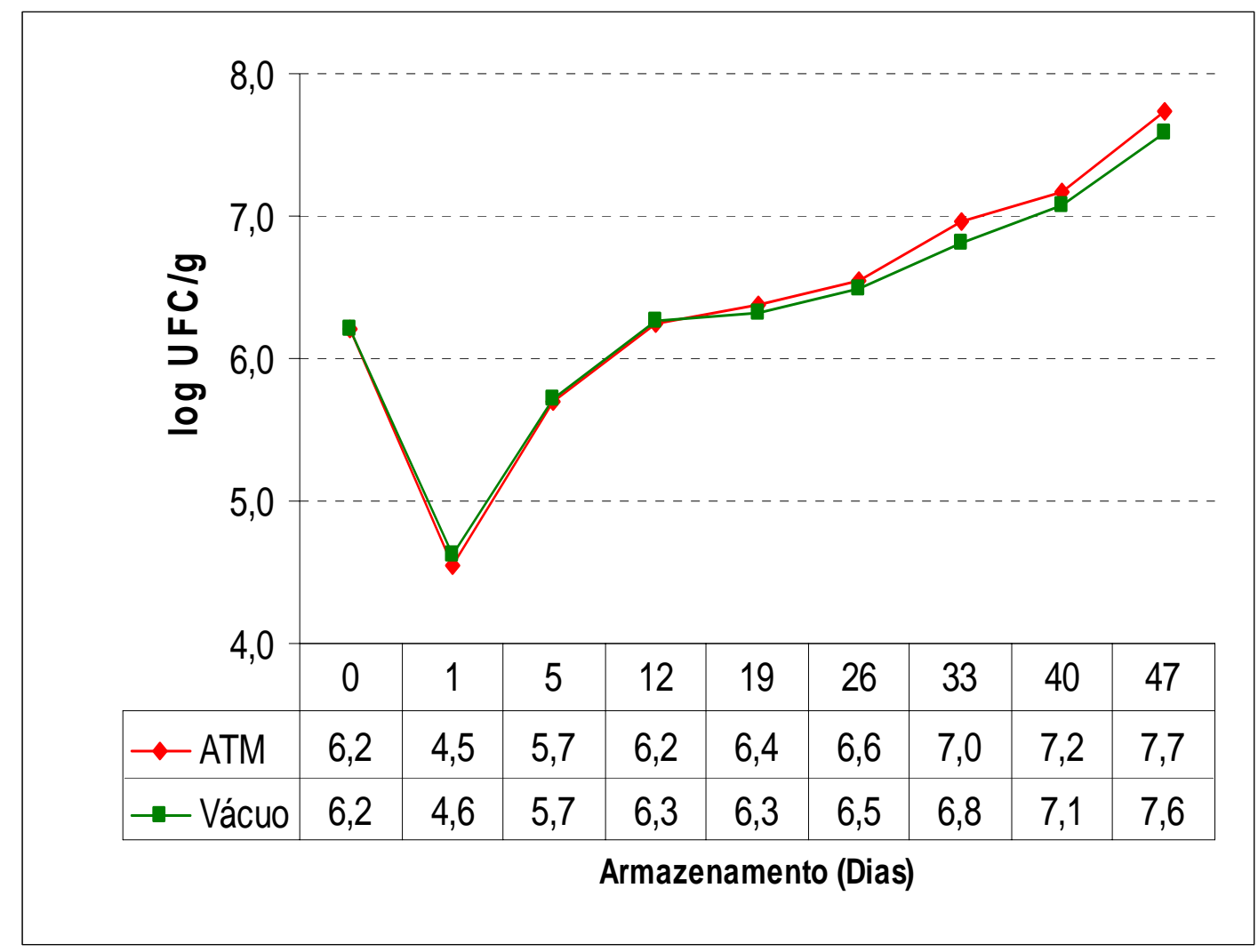

Figura 20 - Evolução da população de psicrotróficos anaeróbios em queijos Minas Frescal irradiados com 2 KGy embalados sob atmosfera modificada (ATM: $70 \% \mathrm{CO}_{2} / 30 \% \mathrm{~N}_{2}$ ) e Vácuo durante o armazenamento a $4^{\circ} \mathrm{C}$.

\subsubsection{Evolução da população de Staphylococcus coagulase positiva}

A Figura 21 mostra a população de Staphylococcus coagulase positiva em queijo Minas Frescal irradiados com 2 KGy embalados sob ar atmosférico (Controle), atmosfera modificada (ATM: $70 \% \mathrm{CO}_{2} / 30 \% \mathrm{~N}_{2}$ ) e Vácuo durante 0 armazenamento a $4^{\circ} \mathrm{C}$ por 47 dias. A população foi muito reduzida pela irradiação a 2 KGy, ficando abaixo do limite de detecção do método ( $<1$ UFC/g). 
Em algumas amostras posteriores o microrganismo foi detectado. No queijo embalado a Vácuo, houve detecção bem abaixo da inicial (0,3 log UFC/g), encontrada a partir do $26^{\circ}$ dia até o $47^{\circ}$ dia. No tratamento com ATM, a população não foi detectada após o $40^{\circ}$ dia. É difícil atribuir esta população à proliferação. Afinal no estudo sem irradiação (Figura 9), Staphylococcus não pode se multiplicar, havendo também o declínio da população.

Neste caso as células microbianas foram submetidas ao tratamento de irradiação; que provocam uma série de alterações características do fenômeno da injúria, tais como um aumento da sensibilidade, perda de componentes celulares, danos na membrana celular, aumento da fase lag, incapacidade de multiplicação e outros (Leitão, 1988). Assim esta detecção deve significar mais uma população residual sobrevivente detectada em algumas amostras do que uma multiplicação.

Além da injúria, outra barreia que impossibilitaria o desenvolvimento do Staphylococcus foi a utilização de baixas temperaturas $\left(4^{\circ} \mathrm{C}\right)$, pois este grupo é formado por bactérias mesófilas que apresentam temperatura para crescimento entre 7 a $48^{\circ} \mathrm{C}$, sendo $37^{\circ}$ a temperatura ótima, e para a produção de toxina vai de 10 a $48^{\circ} \mathrm{C}$, sendo 40 a $45^{\circ}$ a faixa ótima (Speck, 1992; Holt et al., 1994 e ICMFS, 1998).

Assim, pode-se concluir que a utilização da irradiação com dose de 2 KGy, juntamente com a aplicação de atmosfera modificadas e baixas temperaturas provocam a redução e dificultam o crescimento do Staphylococcus coagulase positiva. 


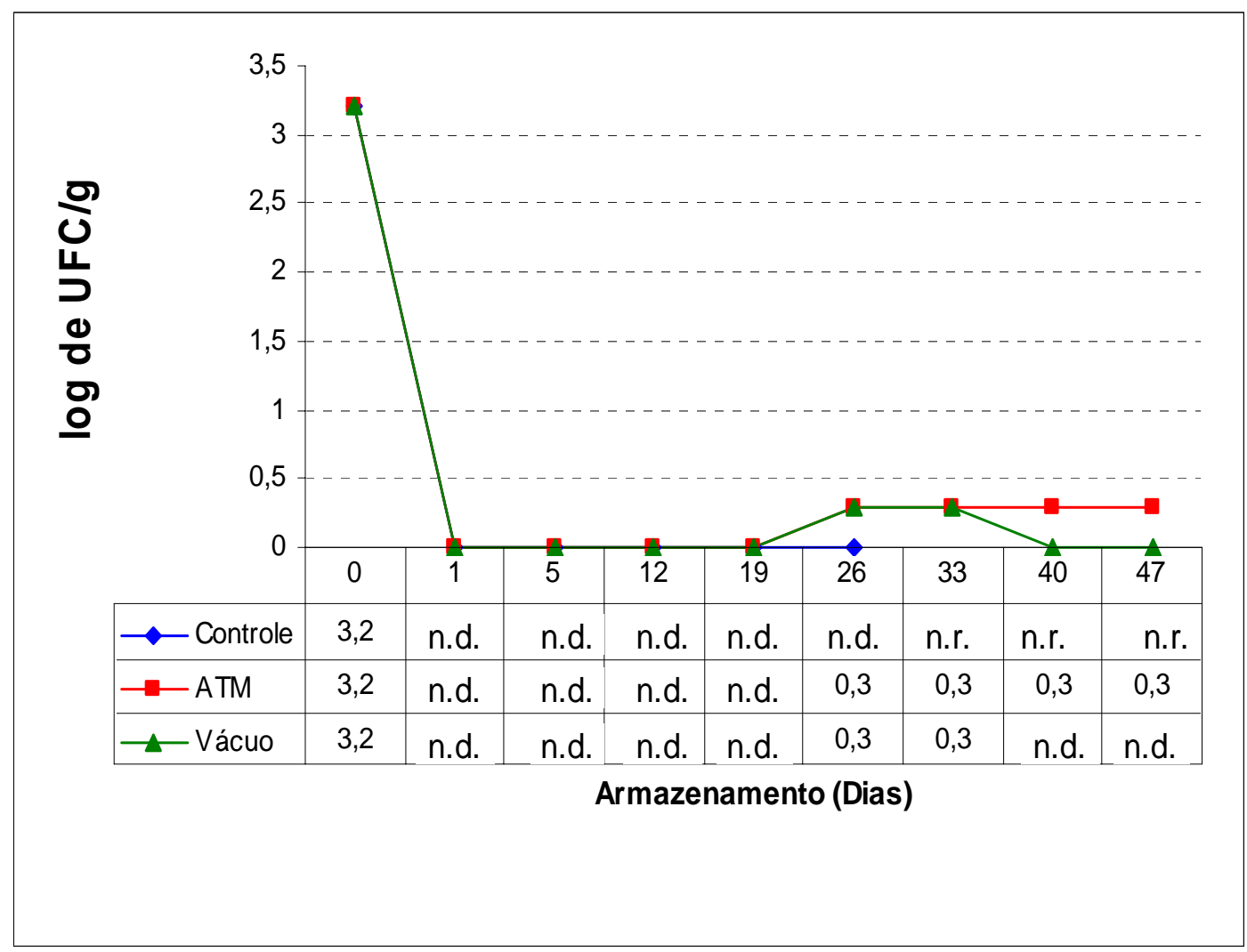

Figura 21 - Evolução da população de Staphylococcus coagulase positiva em queijos Minas Frescal irradiados com 2 KGy embalados sob ar atmosférico (Controle), atmosfera modificada (ATM: $70 \% \mathrm{CO}_{2} / 30 \% \mathrm{~N}_{2}$ ) e Vácuo durante o armazenamento a $4^{\circ} \mathrm{C}$.

n.d.: contagem não detectada (<1UFC/g).

n.r.: análise não realizada.

\subsubsection{Evolução da população de coliformes totais}

Na Figura 22 consta o resultado da população de Coliformes Totais em queijos Minas Frescal irradiados com 2 KGy embalados sob ar atmosférico (Controle), ATM e Vácuo e durante o armazenamento a $4^{\circ} \mathrm{C}$ por 47 dias. No Controle, após a irradiação, a contagem de coliformes fecais foi $<0,3 \mathrm{NMP} / \mathrm{g}$ 
durante os 12 dias de armazenamento. Nos queijos embalados sob atmosfera modificada e irradiados, a população inicial (2,3 log de UFC/g) foi reduzindo-se continuamente até chegar a $<0,3 \mathrm{NMP} / \mathrm{g}$ no $40^{\circ} \mathrm{dia}$, o qual se manteve até o final do armazenamento. O mesmo comportamento ocorreu nos queijos embalados a Vácuo em que a população inicial de 1,44 log de UFC/g decresceu até chegar a $<0,3 \mathrm{NMP} / \mathrm{g}$ no $40^{\circ} \mathrm{dia}$, a qual se manteve até o final do armazenamento.

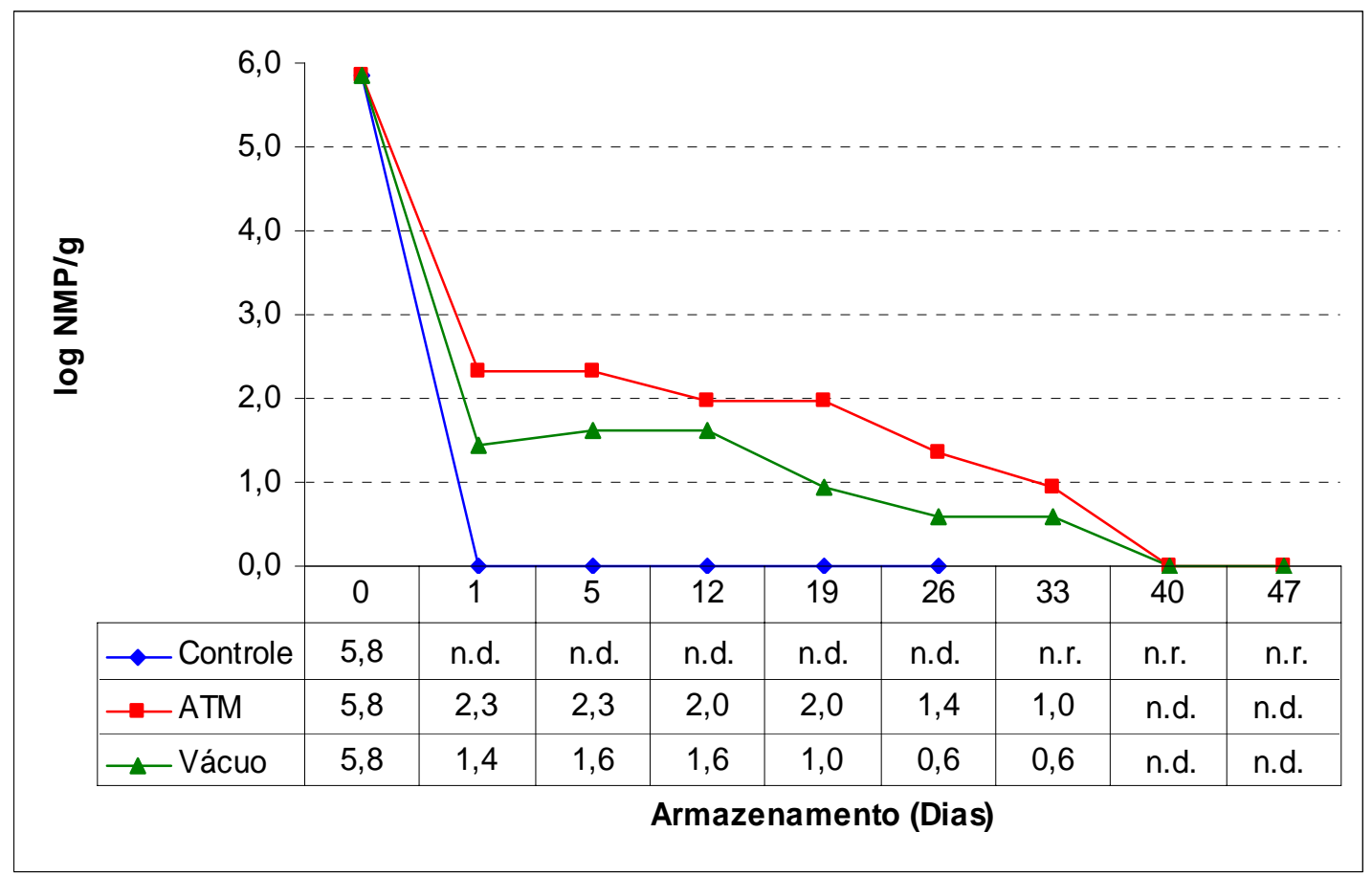

Figura 22 - Evolução da população de Coliformes Totais em queijos Minas Frescal irradiados com 2 KGy embalados sob ar atmosférico (Controle), atmosfera modificada (ATM: $70 \% \mathrm{CO}_{2} / 30 \% \mathrm{~N}_{2}$ ) e Vácuo durante o armazenamento a $4^{\circ} \mathrm{C}$.

n.r.: análise não realizada.

n.d.: não detectada (contagem < 0,3 NMP/g). 
Pode-se concluir que os tratamentos utilizados ATM e Vácuo e irradiação foram eficazes, pois eles impediram o crescimento dos coliformes no queijo Minas Frescal, ocasionando a diminuição da população até atingir contagens inferiores a 0,3 NMP/g.

Comparando estes resultados com a primeira parte do experimento (Figura 10), verifica-se que não ocorreu o mesmo, pois lá os coliformes totais tiveram uma fase de crescimento contínuo durante os primeiros 21 dias de armazenamento, o qual não ocorreu nesta etapa (Figura 22), e após tiveram uma fase de declínio nos queijos sob ATM e Vácuo. A irradiação, portanto, potencializou a eficiência dos tratamentos ATM e Vácuo.

\subsubsection{Contagem de Escherichia coli}

Na Figura 23 consta a contagem da população de Escherichia coli em queijos Minas Frescal irradiados com 2 KGy embalados sob ar atmosférico (Controle), ATM e Vácuo durante o armazenamento a $4^{\circ} \mathrm{C}$ por 47 dias. $\mathrm{O}$ comportamento desta população foi similar ao do grupo de coliformes totais. No Controle, houve redução de coliformes fecais para $<0,3 \mathrm{NMP} / \mathrm{g}$ durante os 12 dias de armazenamento. Nos queijos embalados sob atmosfera modificada e irradiados, a população inicial (1,84 log de UFC/g) foi reduzindo-se continuamente até chegar à contagem $<0,3 \mathrm{NMP} / \mathrm{g}$ no $33^{\circ}$ dia, a qual se manteve até o final do armazenamento. O mesmo comportamento ocorreu nos queijos embalados a Vácuo, em que a população inicial de 0,84 log de UFC/g decresceu até chegar a $<0,3 \mathrm{NMP} / \mathrm{g}$ no $26^{\circ} \mathrm{dia}$, o qual se manteve até o final do armazenamento.

Conclui-se que os tratamentos utilizados ATM e Vácuo mais irradiação foram eficazes, pois impediram o crescimento da Escherichia coli no queijo Minas Frescal, ocasionando a diminuição da população até atingir contagens inferiores a 0,3 NMP/g. 


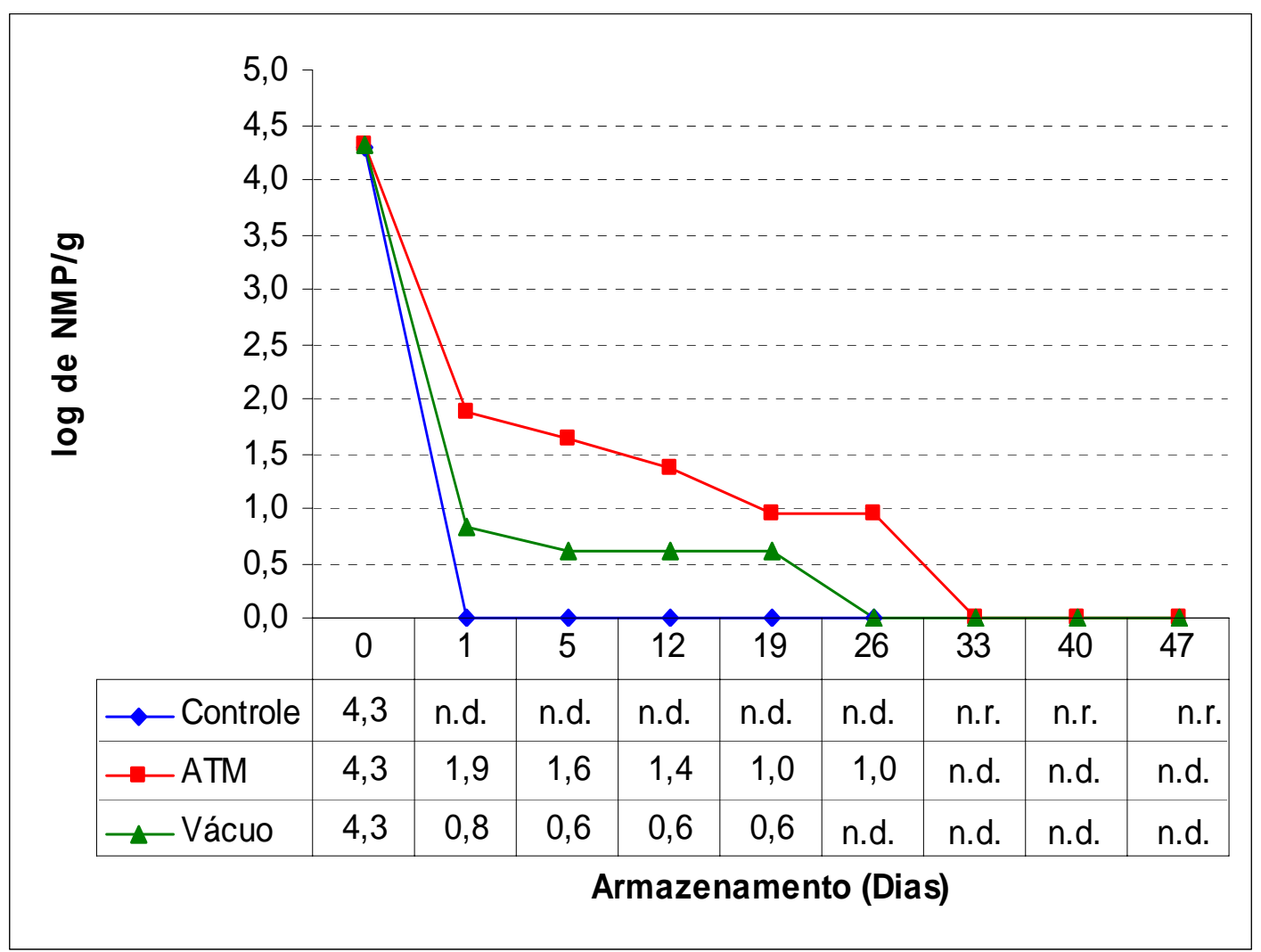

Figura 23 - Evolução da população de Escherichia coli em queijos Minas Frescal irradiados com 2KGy embalados sob ar atmosférico (Controle), atmosfera modificada (ATM: $70 \% \mathrm{CO}_{2} / 30 \% \mathrm{~N}_{2}$ ) e Vácuo durante o armazenamento a $4^{\circ} \mathrm{C}$.

n.r.: análise não realizada.

n.d.: contagem não detectada (<0,3 NMP/g).

Comparando estes resultados com a primeira parte do experimento (Figura 11), verifica-se comportamento diferente, pois a população de Escherichia coli teve uma fase de crescimento durante os primeiros 21 dias de armazenamento, a qual não ocorreu nesta etapa (Figura 23), e após houve uma fase de declínio nos queijos sob ATM e Vácuo, chegando a contagens de 2 log de UFC/g para ambos os tratamentos (ATM e Vácuo). No Controle houve 
crescimento da população durante o armazenamento, tanto para os queijos irradiados, como não irradiados.

\subsection{Análises físico-químicas}

\subsubsection{Resultados obtidos com o queijo Minas Frescal sob atmosfera modificada}

Na composição físico-química do produto pôde-se encontrar os valores descritos na Tabela 3.

Tabela 3. Resultados obtidos nas análises físico-químicas do queijo Minas Frescal.

\begin{tabular}{cc}
\hline Parâmetros & Valores \\
\hline pH & 6,40 \\
Gordura (\%) & 20,50 \\
Gordura no extrato seco (\%) & 54,60 \\
Umidade (\%) & 62,50 \\
Proteína bruta (\%) & 12,40 \\
Cinzas (\%) & 1,86 \\
Acidez (\%) & 0,281 \\
\hline
\end{tabular}

Este queijo, segundo a Portaria n ${ }^{0} .146$ de 7 de março de 1996 do Ministério da Agricultura e do Abastecimento, é classificado com um queijo semi-magro e de alta umidade. Os principais efeitos provocados pelo alto teor de umidade nos queijos incluem a diminuição do valor nutritivo e o favorecimento da multiplicação microbiana decorrente da elevada atividade de água no produto, o que foi facilmente observado neste estudo. Microrganismos, 
como coliformes, cresceram mesmo sob Vácuo, ATM e refrigeração, demonstrando que este tipo de queijo é um excelente substrato.

Os resultados dos valores de $\mathrm{pH}$ podem ser observados na Figura 24, no Controle o pH inicial de 6,4 reduziu-se para 4,95 em 17 dias. Para ATM e Vácuo o pH diminuiu de 6,4 para 4,53 no ATM e 4,45 no Vácuo durante 40 dias.

$\mathrm{O} \mathrm{pH}$ do queijo diminuiu para os dois tratamentos durante a estocagem. Outros autores também observaram este decréscimo (Faber, 1991; Fandos et al. 2000, Pintado \& Malcata 2000 e Olarte et al. 2002).

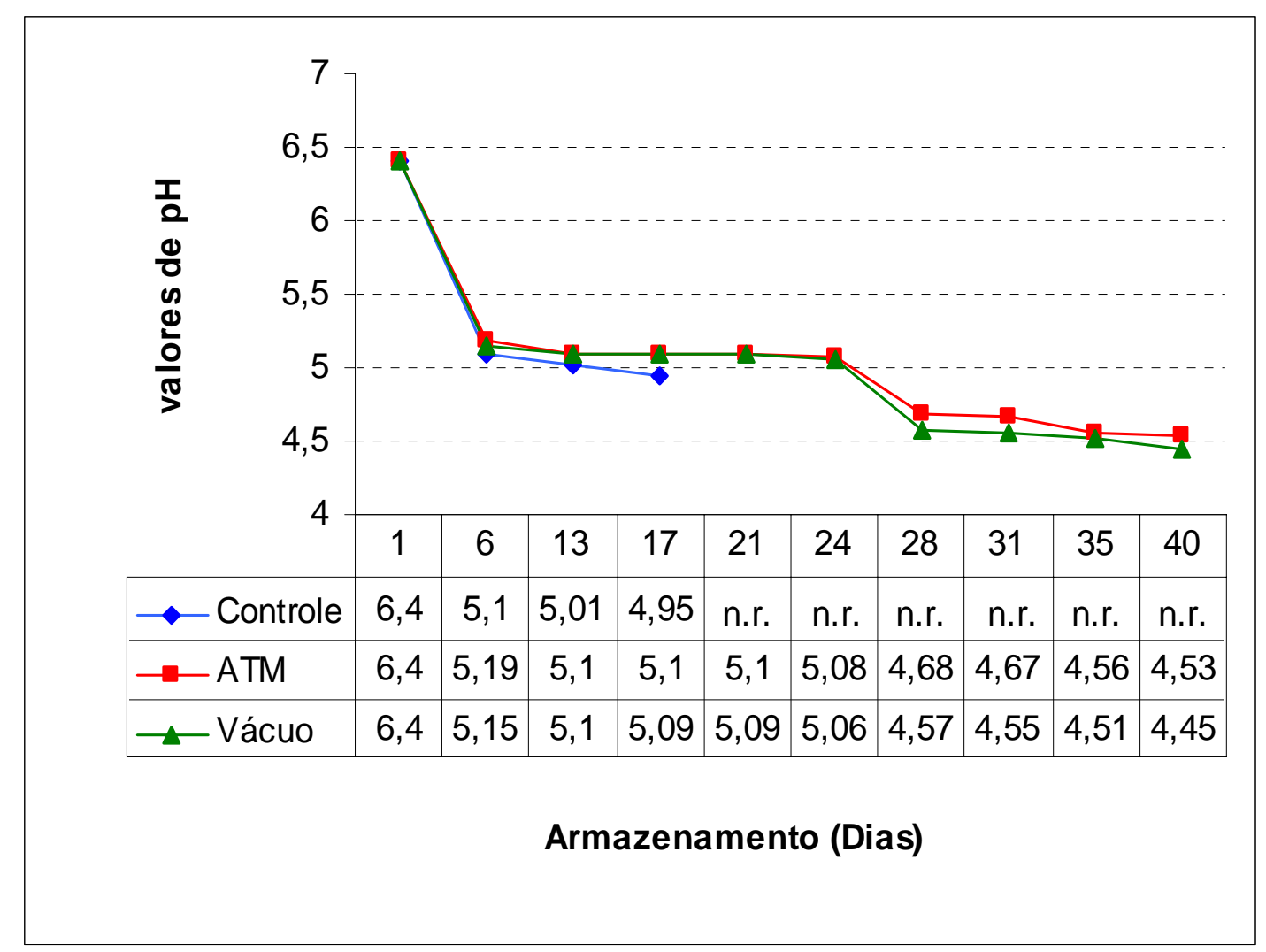

Figura 24 - Evolução dos valores de pH em queijos Minas Frescal embalados sob ar atmosférico (Controle), atmosfera modificada (ATM: $70 \% \mathrm{CO}_{2} / 30 \% \mathrm{~N}_{2}$ ) e Vácuo durante o armazenamento a $4^{\circ} \mathrm{C}$.

n.r: análise não realizada. 
Na Figura 25 constam os valores de acidez dos queijos Minas Frescal embalados sob ar atmosférico (Controle), atmosfera modificada (ATM: $70 \% \mathrm{CO}_{2} / 30 \% \mathrm{~N}_{2}$ ) e Vácuo. Para todos os tratamentos pode-se verificar que a acidez aumentou durante a estocagem, em que a acidez inicial de 0,281\% subiu para $0,369 \%$ para o Controle até o $17^{\circ}$ dia de armazenamento, e 0,379\% para o ATM no $40^{\circ}$ dia e $0,353 \%$ para o Vácuo no $40^{\circ}$ dia.

O aumento de acidez em queijos frescos também foi demonstrado em trabalhos realizados com queijo e atmosfera modificada por Maniar et al. (1994) e Pintado \& Malcata (2000).

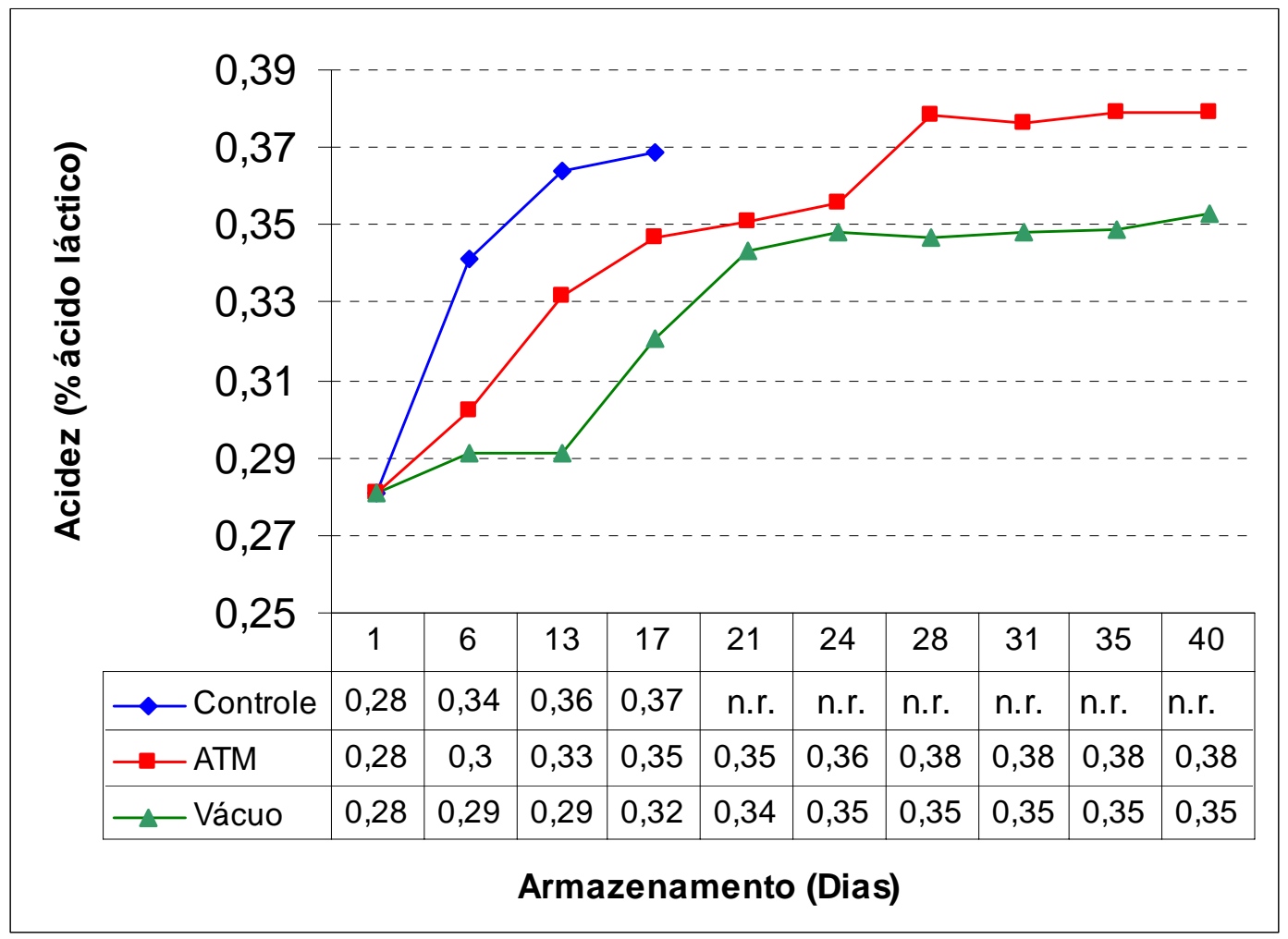

Figura 25 - Evolução dos valores de acidez em queijos Minas Frescal embalados sob ar atmosférico (Controle), atmosfera modificada (ATM) e Vácuo durante o armazenamento a $4^{\circ} \mathrm{C}$.

n.r.: análise não realizada. 
Durante todo o armazenamento, não foi verificado resultado positivo para a prova de rancidez. Isto provavelmente ocorreu devido ao fato do queijo Minas Frescal possuir baixo teor de gordura e não ter etapa de maturação durante 0 seu processamento, a qual aumenta a lipólise em geral.

\subsubsection{Resultados obtidos com o queijo Minas Frescal sob atmosfera modificada e irradiado}

Na composição físico-química do produto antes e depois do processo de irradiação, pode-se encontrar os valores descritos na Tabela 4.

Tabela 4. Resultados obtidos nas análises físico-químicas do queijo Minas Frescal antes e depois de irradiados.

\begin{tabular}{lcc}
\hline Parâmetros & Queijo Não Irradiado & Queijo Irradiado \\
\hline PH & 6,71 & 6,42 \\
Gordura (\%) & 18,4 & 18,5 \\
Gordura no extrato seco (\%) & 51,54 & 50,82 \\
Umidade (\%) & 64,3 & 63,2 \\
Proteína Bruta (\%) & 14,3 & 14,7 \\
Cinzas (\%) & 1,94 & 1,91 \\
Acidez (\% em ácido lático) & 0,294 & 0,301 \\
\hline
\end{tabular}

$\mathrm{Na}$ Tabela 4, pode-se observar que houve uma alteração mínima na composição físico-química do queijo Minas Frescal, havendo apenas uma diminuição no teor de acidez e pH e conseqüente aumento no índice de acidez. Assim, conclui-se que a irradiação não alterou as características físico-químicas do queijo Minas Frescal.

$\mathrm{Na}$ Figura 26, verifica-se a evolução dos valores de pH em queijos Minas Frescal embalados sob ar atmosférico (Controle) e irradiados, Vácuo e 
irradiados e atmosfera modificada (ATM: $70 \% \mathrm{CO}_{2} / 30 \% \mathrm{~N}_{2}$ ) e irradiados durante a estocagem a $4^{\circ} \mathrm{C}$. Na Figura nota-se que houve um declínio contínuo dos valores de $\mathrm{pH}$ em que os valores iniciais de 6,42 diminuíram para 5,67 no $17^{\circ}$ dia de armazenamento do Controle, de 5,02 e 5,10 no $47^{\circ}$ dia de armazenamento para o ATM e Vácuo, respectivamente.

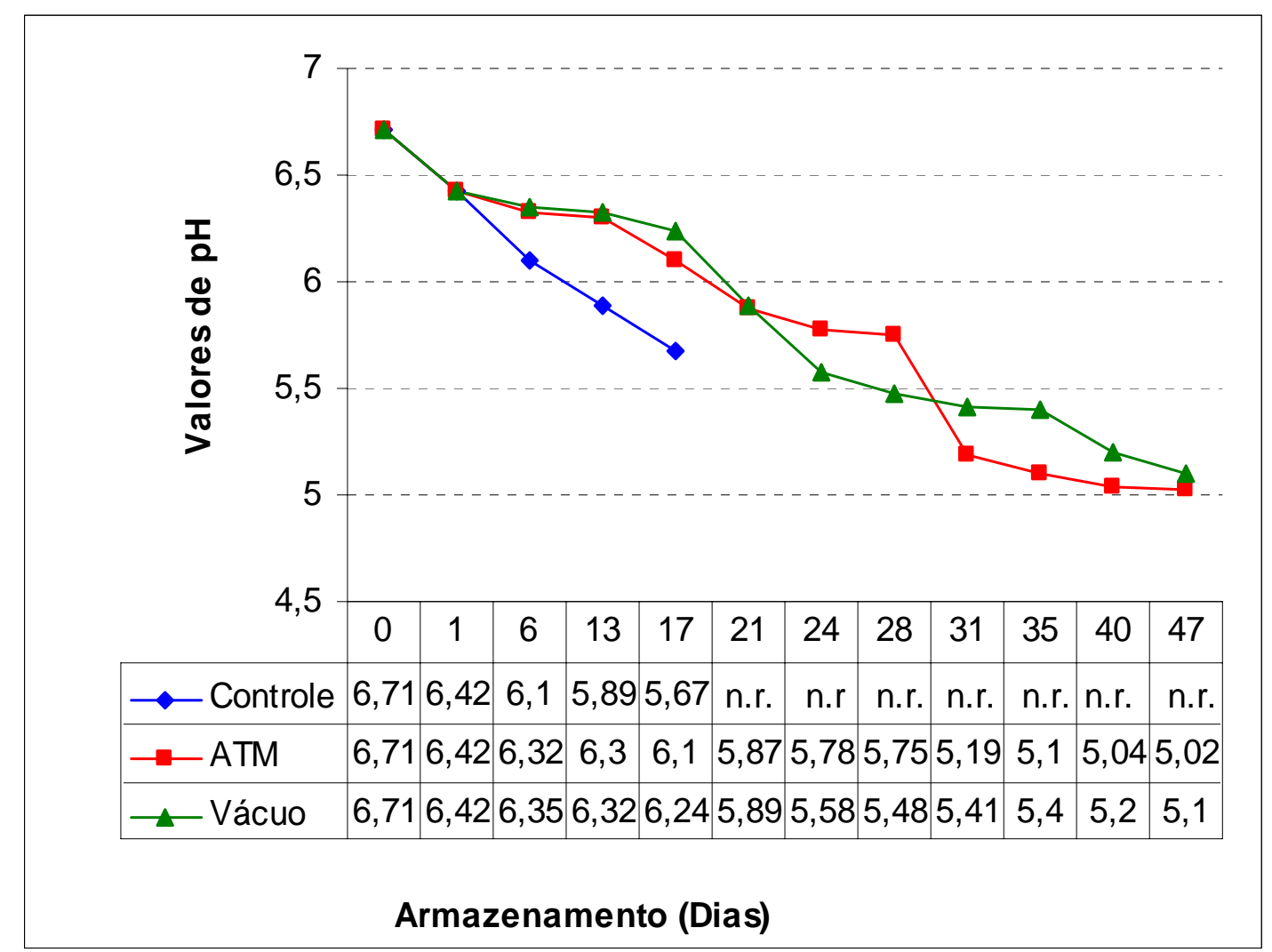

Figura 26 - Evolução dos valores de pH em queijos Minas Frescal irradiados com 2KGy embalados sob ar atmosférico (Controle), atmosfera modificada (ATM: $70 \% \mathrm{CO}_{2} / \quad 30 \% \mathrm{~N}_{2}$ ) e Vácuo durante o armazenamento a $4^{\circ} \mathrm{C}$.

n.r.: análise não realizada. 
Durante o armazenamento, os valores de $\mathrm{pH}$ apresentaram uma diminuição devido à fermentação da lactose produzida pelas bactérias (Furtado \& Lourenço Neto, 1994; Bourgeois et al., 1994)

Os valores de pH variaram entre 6,42 e 5,02 e são superiores aos encontrados por Bonassi (1979) e Casagrande \& Wolfschoon-Pombo (1988), cujos valores de $\mathrm{pH}$ variam entre 4,72 e 4,96 determinados aos 10, 20, 30 dias e 4,96, 4,79 e 4,58 aos 1, 6 e 14 dias, respectivamente.

Os resultados deste trabalho estão de acordo com Furtado et al (1980), que ao estudar diferentes processos de fabricação desse tipo de queijo, encontraram valores médios de $\mathrm{pH}$ em torno de 6,45 e 6,39 determinados no $1^{\circ}$ e $6^{\circ}$ dia de armazenamento e com Isepon \& Oliveira (1995), que encontraram valores médios de pH em torno de 6,41.

Na Figura 27, verifica-se a evolução dos índices de acidez em queijos Minas Frescal embalados sob ar atmosférico (Controle) e irradiados, Vácuo e irradiados e atmosfera modificada (ATM: $70 \% \mathrm{CO}_{2} / 30 \% \mathrm{~N}_{2}$ ) e irradiados durante a estocagem a $4^{\circ} \mathrm{C}$. Na figura observa-se que há um aumento dos valores de acidez onde valores iniciais de 0,301 subiram para 0,315 no $17^{\circ}$ dia de armazenamento do Controle, de 0,369 e 0,375 no $47^{\circ}$ dia de armazenamento para o ATM e Vácuo, respectivamente. O aumento do teor de acidez provavelmente, foi por causa das bactérias produtoras de ácidos ou pela dissolução do gás carbônico no produto. Nesta parte do experimento também não foi verificado resultado positivo para a prova de rancidez, durante todo o armazenamento. 


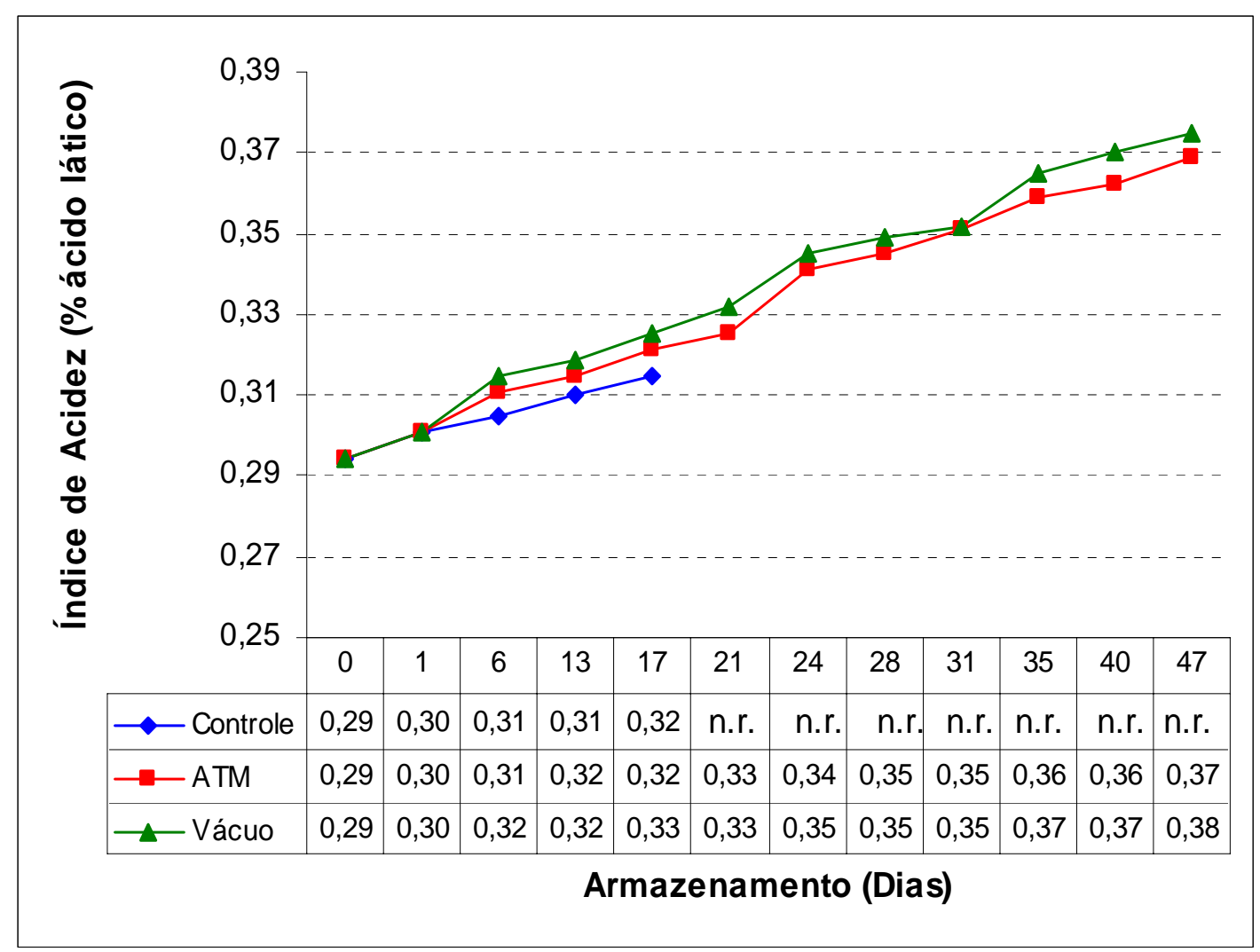

Figura 27 - Evolução dos índices de acidez em queijos Minas Frescal irradiados com 2 KGy embalados sob ar atmosférico (Controle), atmosfera modificada (ATM: $70 \% \mathrm{CO}_{2} / 30 \% \mathrm{~N}_{2}$ ) e Vácuo durante o armazenamento a $4^{\circ} \mathrm{C}$.

n.r.: análise não realizada. 


\subsection{Evolução da atmosfera}

\subsubsection{Resultados obtidos com o queijo Minas Frescal sob atmosfera modificada}

A evolução da composição gasosa dentro das embalagens foi estudada durante todo o período de armazenamento, por esta variável influenciar o desenvolvimento da microbiota naturalmente presente no alimento embalado.

Os resultados podem ser observados na Figura 28 em que a concentração de $\mathrm{CO}_{2}$ inicial (69\%) diminuiu até $13^{\circ}$ dia de estocagem, atingindo até $54,6 \%$, após retornou a subir gradativamente atingindo valores $63,4 \%$. A

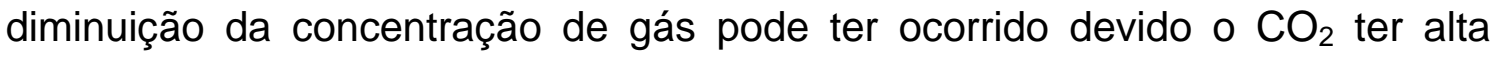
solubilidade em água e o queijo Minas Frescal possuir um alto teor de umidade. $\mathrm{O}$ declínio da concentração de $\mathrm{CO}_{2}$ também pode ser observado em trabalhos com queijo tipo Cottage realizados por Scott \& Smith (1971); Chen \& Hotchkiss (1993); Moir et al. (1993); Olarte et al. (2002) e Juric et al. (2003).

Mannheim \& Soffer (1996) verificaram que, durante a estocagem, a dissolvibilidade de $\mathrm{CO}_{2}$ aumenta em queijo tipo Cottage, diminuindo a concentração do gás dentro da embalagem.

Já, Eliot et al. (1998) verificaram que a concentração de $\mathrm{CO}_{2}$ em queijo mussarela embalado a Vácuo manteve-se estável. Isto pode ser justificado pela baixa umidade do produto, dificultando a solubilidade do gás no alimento.

O teor inicial de nitrogênio foi de 28,2\%, havendo um aumento na primeira semana para $37,9 \%$, a partir daí houve pequenas oscilações durante a estocagem, e a concentração final foi de $36,1 \%$. As oscilações no teor de nitrogênio também foram observadas por Eliot et al. (1998).

A concentração de oxigênio manteve-se menor que $1 \%$ durante todo o período de armazenamento do produto. Isto foi devido à baixa permeabilidade de oxigênio da embalagem, a qual evitou a troca gasosa com a atmosfera. $O$ 
baixo índice de oxigênio também foi demonstrado em trabalhos realizados por Eliot et al.(1998) e Fandos et al. (2000).

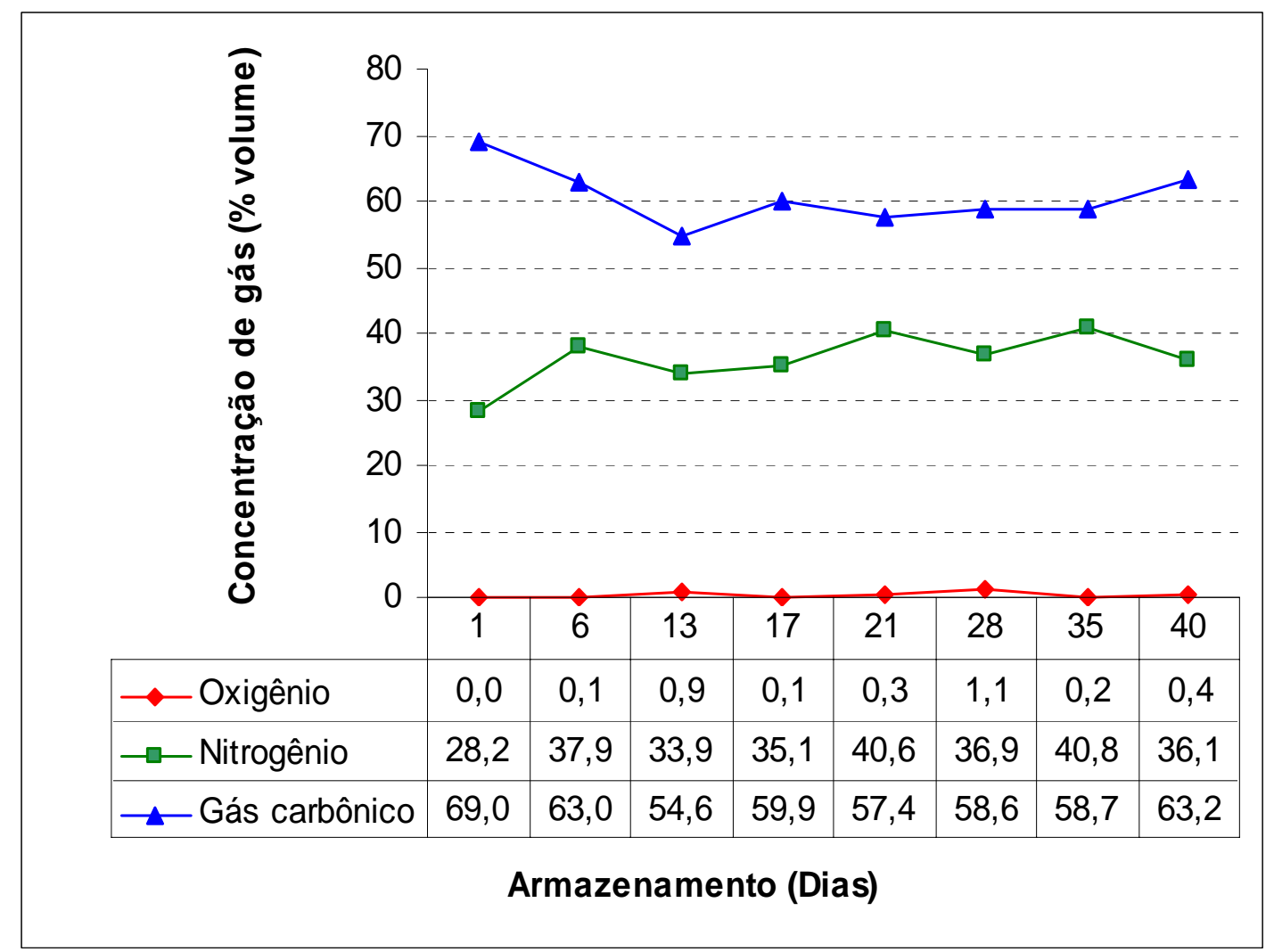

Figura 28 - Curva média da composição gasosa dentro da embalagem do queijo Minas Frescal embalado sob atmosfera modificada.

Na Figura 29 constam as médias da composição gasosa dentro das embalagens de queijo Minas Frescal embalados sob atmosfera modificada e irradiados, assim verifica-se que houve um declínio nas concentrações de $\mathrm{CO}_{2}$ até $012^{\circ}$ dia de armazenamento, aumentando no $19^{\circ}$ dia e diminuindo novamente no $26^{\circ}$ dia. Nos dias seguintes houve um aumento atingindo $78,2 \%$ de $\mathrm{CO}_{2}$.

$\mathrm{Na}$ concentração de $\mathrm{N}_{2}$, inicialmente observou-se um aumento, com posterior declínio no $21^{\circ}$ dia de armazenamento, após houve aumento seguido 
de declínio chegando a $24,1 \%$ de $\mathrm{CO}_{2}$ no $40^{\circ}$ dia de armazenamento. $\mathrm{O}$ residual de oxigênio manteve-se em zero, com exceção do $33^{\circ}$ dia havendo $1,9 \% \mathrm{O}_{2}$.

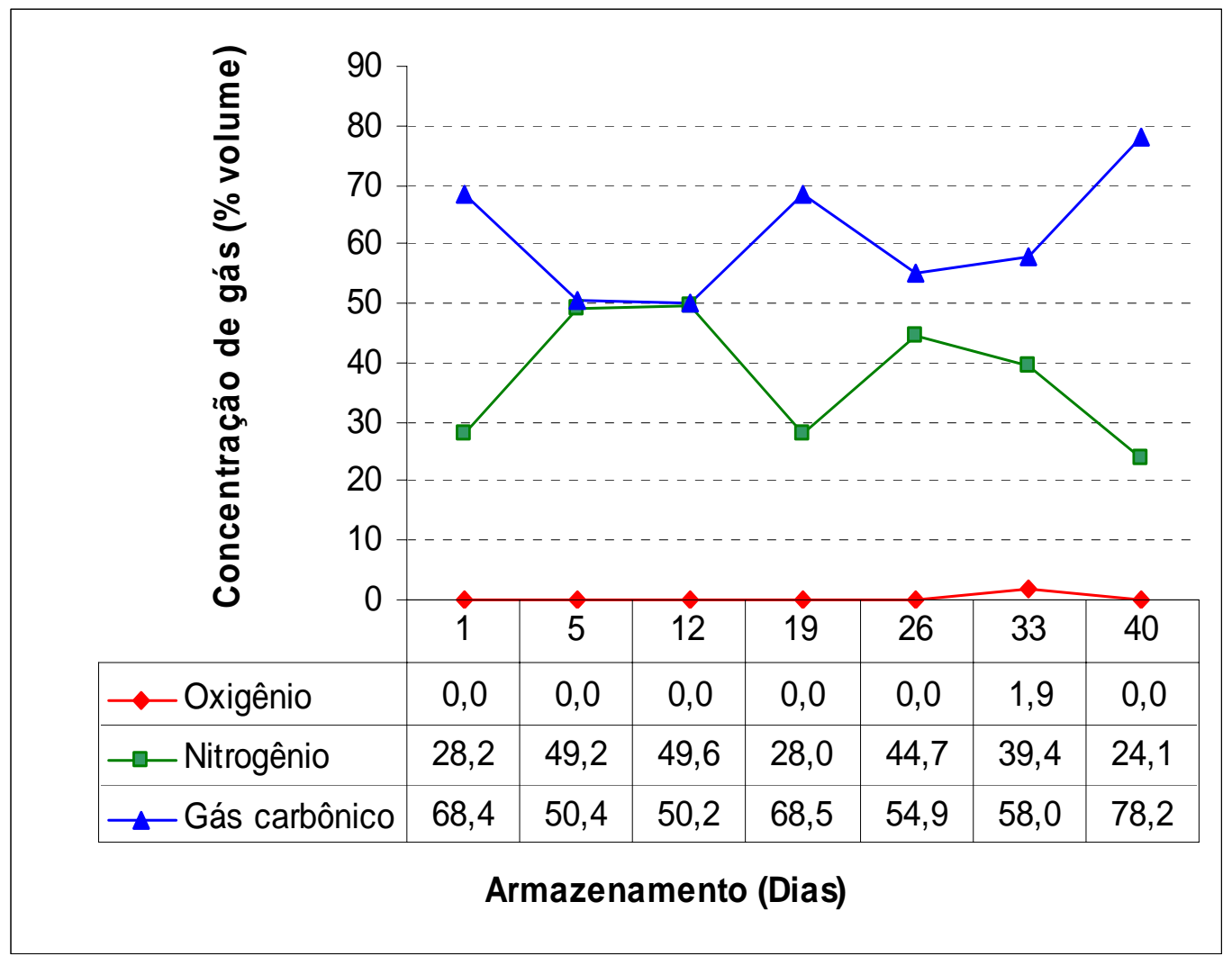

Figura 29 - Curva média da composição gasosa dentro da embalagem do queijo Minas Frescal embalado sob atmosfera modificada e irradiado. 


\subsection{Análises sensoriais}

\subsubsection{Resultados obtidos com o queijo Minas Frescal sob atmosfera modificada}

Devido ao queijo não apresentar boas condições microbiológicas, a análise sensorial restringiu-se apenas as características visuais e de odor.

\subsubsection{Cor}

Na Figura 30, estão representados índices de aceitabilidade da cor do queijos Minas Frescal embalados sob ar atmosférico (Controle), Vácuo e atmosfera modificada (ATM: $70 \% \mathrm{CO}_{2} / 30 \% \mathrm{~N}_{2}$ ). Os índices de aceitabilidade do Controle foram diminuindo progressivamente até serem rejeitados no $17^{\circ}$ dia de armazenamento, enquanto os demais tratamentos (Vácuo e ATM) mantiveram suas características de cor durante 40 dias, sendo seus índices de aceitabilidade finais de 75,3\% e 74,3\%, respectivamente para ATM e Vácuo.

Segundo as observações dos provadores, estas rejeições foram atribuídas à cor amarelada do produto e ao aparecimento de odores estranhos. As alterações de cor podem ter ocorrido devido a reações químicas ou crescimento de microrganismos produtores de pigmentos, como Pseudomonas syncyanea, que pode causar cor amarelada (Franco \& Landgraf, 1996). 


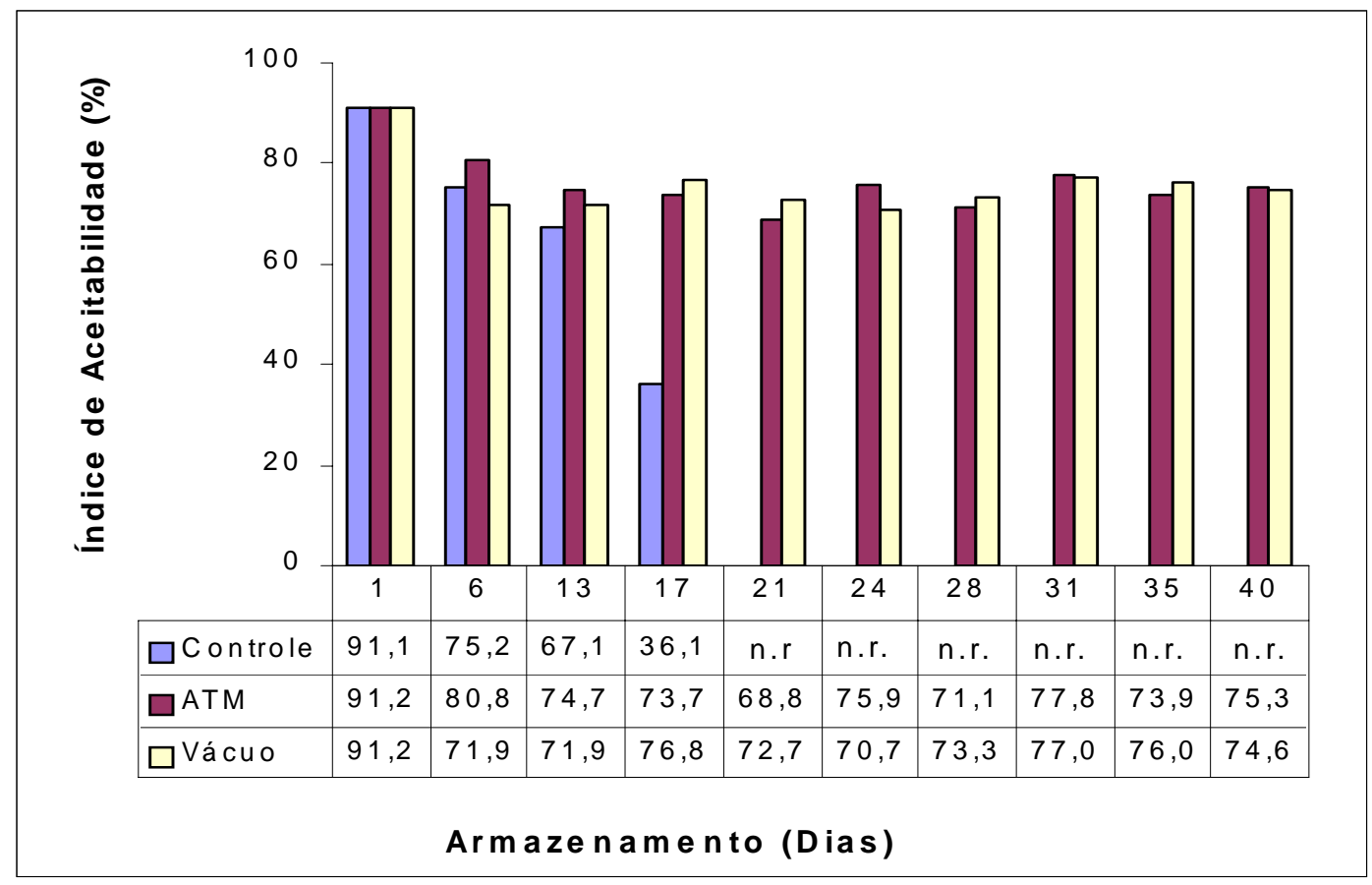

Figura 30 - Índices de aceitabilidade de cor dos queijos Minas Frescal embalados sob ar atmosférico (Controle), Vácuo e atmosfera modificada (ATM: $70 \% \mathrm{CO}_{2} / 30 \% \mathrm{~N}_{2}$ ) durante o armazenamento a $4^{\circ} \mathrm{C}$.

n.r.: análise não realizada.

\subsubsection{Odor}

Na Figura 31, estão representados os índices de aceitabilidade de odor do queijo Minas Frescal embalado sob ar atmosférico (Controle), Vácuo e atmosfera modificada (ATM: $70 \% \mathrm{CO}_{2} / 30 \% \mathrm{~N}_{2}$ ). Para o Controle, os índices de aceitabilidade foram diminuindo progressivamente até serem rejeitados no $17^{\circ}$ dia de armazenamento com apenas $31 \%$ de aceitabilidade. Estes odores 
podem ser decorrentes da multiplicação de diferentes microrganismos, que se multiplicaram rapidamente no Controle (Figuras 2, 3, 5 e 6). Os demais tratamentos (Vácuo e ATM) mantiveram altos índices de aceitabilidade para o odor durante todo o armazenamento, sendo que os dois tratamentos tiveram $73 \%$ de aceitabilidade no $40^{\circ}$ dia.

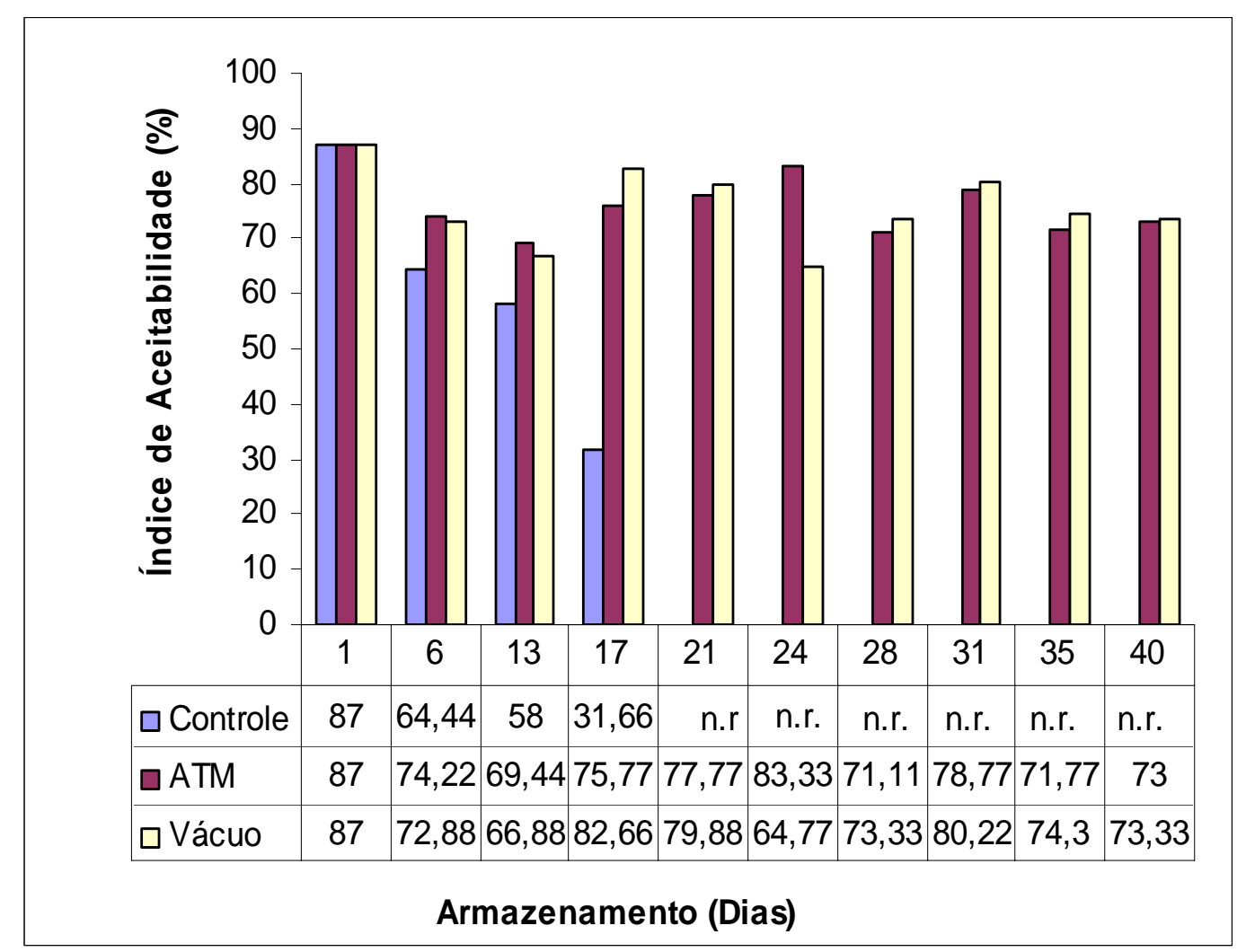

Figura 31 - Índices de aceitabilidade de odor dos queijos Minas Frescal embalados sob ar atmosférico (Controle), Vácuo e atmosfera modificada (ATM: $70 \% \mathrm{CO}_{2} / 30 \% \mathrm{~N}_{2}$ ) durante o armazenamento a $4^{\circ} \mathrm{C}$.

n.r.: análise não realizada. 
No trabalho de Alves et al. (1996), foi feito o teste de aceitabilidade de odor em queijo Mussarela embalado sob ar atmosférico, ATM com $100 \%$ de $\mathrm{N}_{2}$, $100 \% \mathrm{CO}_{2}$ e com $50 \%$ de $\mathrm{N}_{2}+50 \% \mathrm{CO}_{2}$, e os autores verificaram resultados semelhantes aos encontrados no presente trabalho, pois o Controle foi rejeitado no $16^{\circ}$ dia de armazenamento, e os demais tratamentos mantiveram as características de odor durante todo o armazenamento (56 dias).

No trabalho de Manheim \& Soffer (1996), foi feito teste de odor em queijo Cottage embalado com e sem injeção de $\mathrm{CO}_{2}$, e no $13^{\circ}$ dia teve aparecimento de odor pútrido no produto embalado sem $\mathrm{CO}_{2}$.

\subsubsection{Aparência}

Na Figura 32, estão representados os índices de aceitabilidade de aparência geral queijo Minas Frescal embalado sob ar atmosférico (Controle), Vácuo e ATM. Para o Controle, os índices de aceitabilidade foram diminuindo progressivamente até serem rejeitados no $17^{\circ}$ dia de armazenamento com apenas 31\% de aceitabilidade, enquanto os outros tratamentos (ATM e Vácuo) mantiveram altos índices de aceitabilidade até seu $40^{\circ}$ dia de armazenamento, quando foram rejeitados com índices de $67 \%$ e $69 \%$ respectivamente.

Nos trabalhos de Alves et al. (1996) com queijo Mussarela e de Fandos et al. (2000) com queijo fresco de cabra, foi feito também teste de aceitabilidade de aparência geral sendo o Controle rejeitado no $16^{\circ}$ dia para o queijo mussarela e no $20^{\circ}$ dia de armazenamento para o queijo de cabra armazenamento, e o tratamento sob ATM $50 \%$ de $\mathrm{N}_{2}+50 \% \mathrm{CO}_{2}$ mantiveram as características de aparência de 41 e 30 dias, respectivamente, para o queijo Mussarela e de leite de cabra, estes resultados foram similares ao encontrado no presente trabalho. 


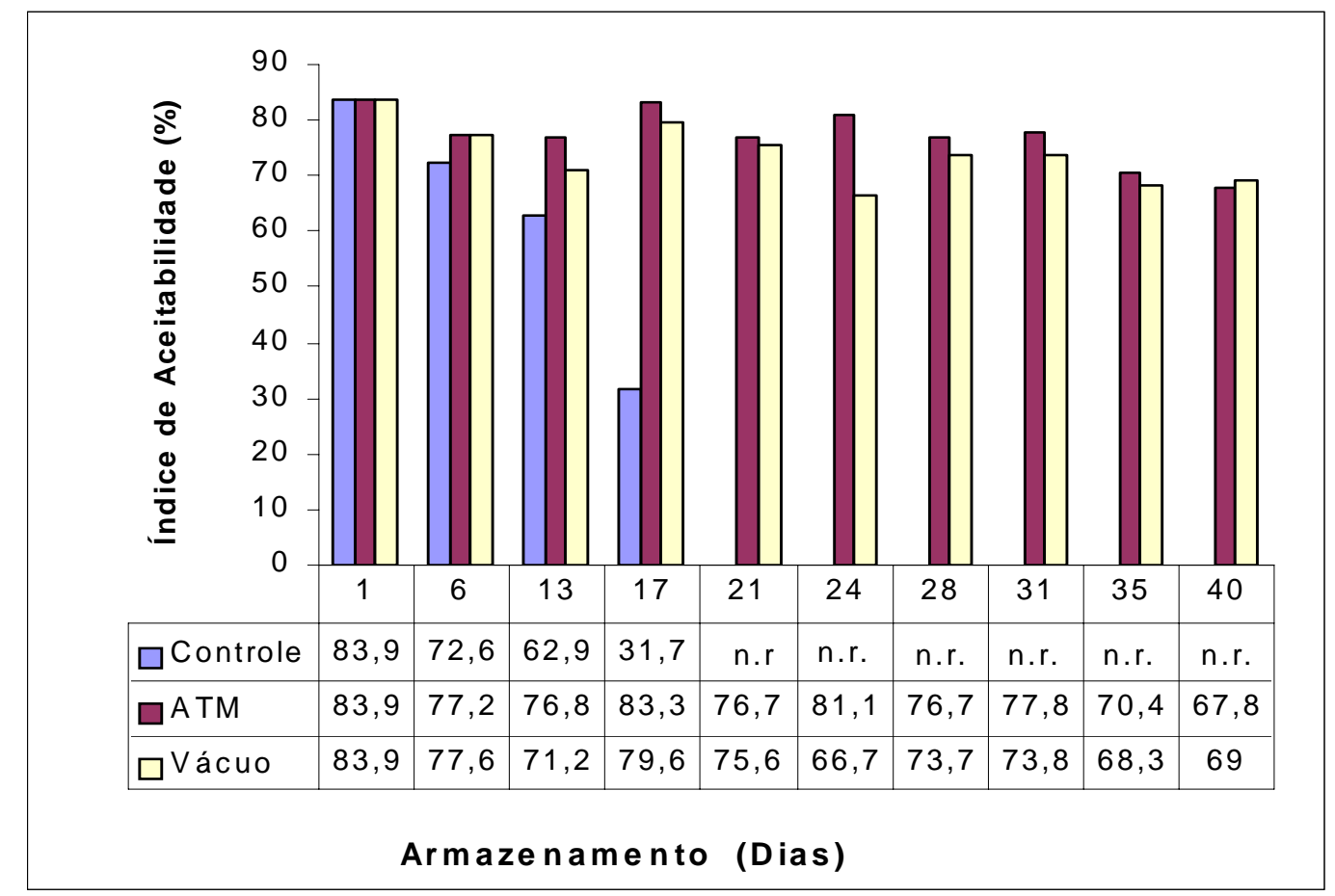

Figura 32 - Índices de aceitabilidade de aparência geral dos queijos Minas Frescal embalados sob ar atmosférico (Controle), Vácuo e atmosfera modificada (ATM: $70 \% \mathrm{CO}_{2} / 30 \% \mathrm{~N}_{2}$ ) durante $\mathrm{o}$ armazenamento a $4^{\circ} \mathrm{C}$.

n.r.: análise não realizada.

A partir do $17^{\circ}$ foi necessário avaliar o produto dentro da embalagem para os tratamentos ATM e Vácuo, visto que, quando exposto na forma de cubos, sua aparência (principalmente perda de soro) não apresentava a exsudação da embalagem.

$\mathrm{Na}$ Figura 33, estão representados índices de aceitabilidade de aparência geral queijo Minas Frescal dentro da embalagem sob Vácuo e atmosfera modificada (ATM: $70 \% \mathrm{CO}_{2} / 30 \% \mathrm{~N}_{2}$ ). Os tratamentos ATM e Vácuo apresentaram um baixo índice de aceitabilidade (55\% para ATM e 54\% para 
Vácuo) no $40^{\circ}$ dia para a aparência geral do produto dentro da embalagem. Esse baixo índice de aceitabilidade pode ter sido pelo produto estar com um grande excesso de soro exsudado, pois metade dos provadores relatou esta situação.

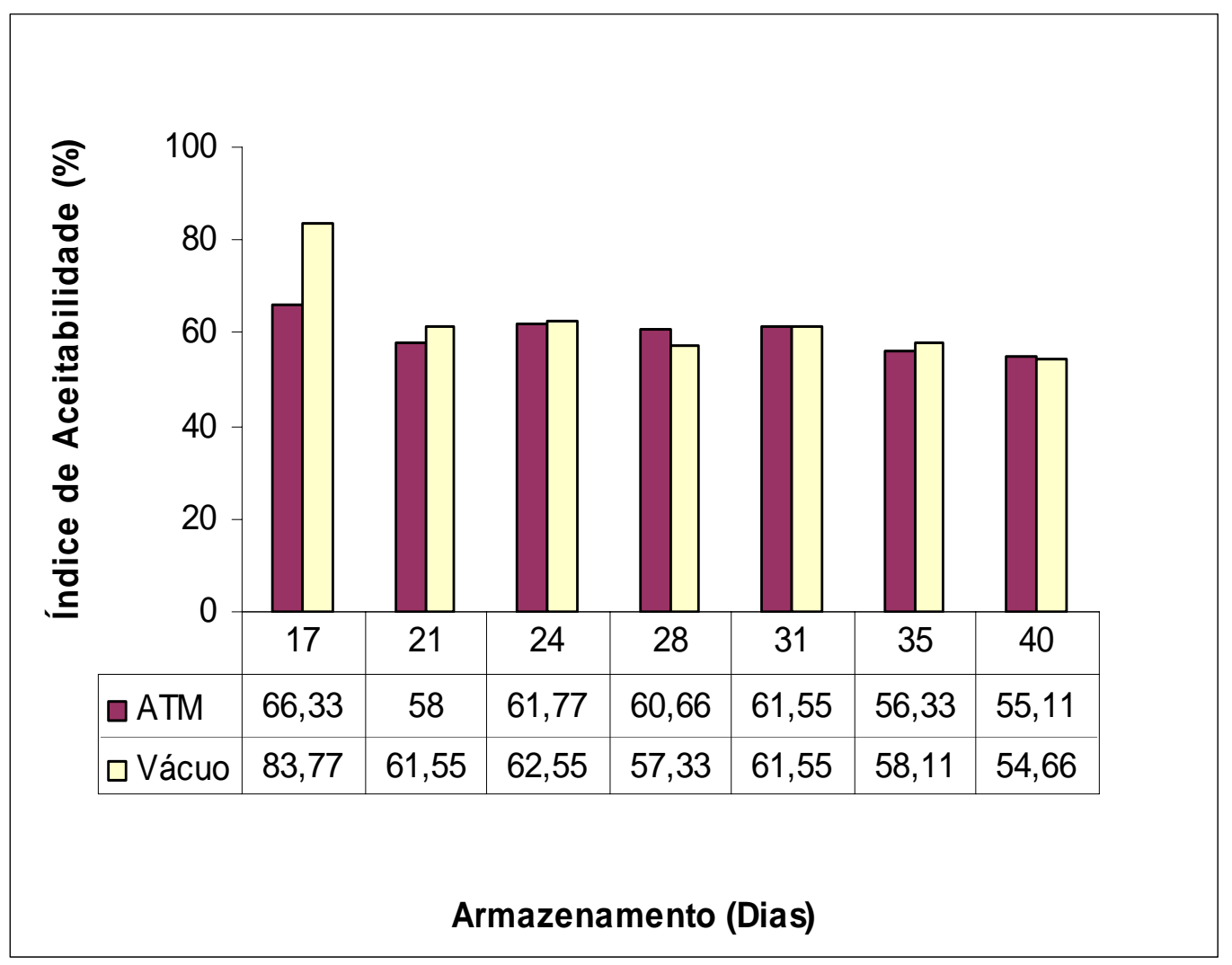

Figura 33 - Índices de aceitabilidade de aparência geral dentro da embalagem dos queijos Minas Frescal embalados sob Vácuo e atmosfera modificada (ATM: $70 \% \mathrm{CO}_{2} / 30 \% \mathrm{~N}_{2}$ ) durante o armazenamento a $4^{\circ} \mathrm{C}$. 


\subsubsection{Resultados obtidos com o queijo Minas Frescal sob atmosfera modificada e irradiado}

A análise de variância com aplicação do teste $F$, foi realizada em duas etapas: em uma houve comparação entre os três tratamentos (Controle, ATM e Vácuo) durante os doze primeiros dias de armazenamento. E após a rejeição do Controle no $12^{\circ}$ dia, fez-se outra comparação entre os tratamentos ATM e Vácuo durante o $22^{\circ}$ e $33^{\circ}$ dia de armazenamento.

\subsubsection{Aparência}

Durante os 12 primeiros dias de armazenamento, o valor $F$ da cor, frescor, brilho e cremoso foram significativos para interação período e tratamento, quando comparados os tratamentos: ATM, Vácuo e Controle; a firmeza foi significativa para tratamento e período; aerado e soroso foram somente significativos para o período (Tabela 5).

Tabela 5. Valor F, obtido da análise de variância, para aparência do queijo Minas Frescal sob os três tratamentos (Controle, ATM e Vácuo) durante os 12 primeiros dias de armazenamento.

\begin{tabular}{llllllll}
\hline & & \multicolumn{5}{c}{ Valor F } \\
\hline & Cor & Frescor & Firmeza & Brilho & Aerado & Soroso & Cremoso \\
Trat. & $212,3^{*}$ & $59,11^{*}$ & $12,56^{\star}$ & $12,39^{*}$ & $2,07 \mathrm{~ns}$ & $0,89 \mathrm{~ns}$ & $39,82^{*}$ \\
Período & $138,48^{\star}$ & $38,46^{\star}$ & $34,59^{\star}$ & $19,88^{*}$ & $21,70^{\star}$ & $14,12^{\star}$ & $7,29 \mathrm{~ns}$ \\
Tx P & $75,02^{*}$ & $28,72^{\star}$ & $6,86 \mathrm{~ns}$ & $7,74^{\star}$ & $2,02 \mathrm{~ns}$ & $0,26 \mathrm{~ns}$ & $13,81^{*}$ \\
\hline
\end{tabular}

Comparando-se a ATM e o Vácuo do $22^{\circ}$ ao $43^{\circ}$ dia de armazenamento, verificou-se que os valores $F$ da cor e frescor foram significativos para interação entre período e tratamento; firmeza foi significativo somente para tratamento; 
soroso foi significativo somente para período; o brilho foi significativo para período e tratamento; aerado e cremoso não obtiveram valor $\mathrm{F}$ significativo (Tabela 6).

Tabela 6. Valor $F$, obtido da análise de variância, para a textura do queijo Minas Frescal sob ATM e Vácuo do $22^{\circ}$ a $43^{\circ}$ dia de armazenamento.

\begin{tabular}{llllllll}
\hline & & \multicolumn{5}{c}{ Valor F } \\
\hline & Cor & Frescor & Firmeza & Brilho & Aerado & Soroso & Cremoso \\
Tratamento & $54,00^{*}$ & $164,23^{*}$ & $157,89^{*}$ & $65,97^{*}$ & $6,86 \mathrm{~ns}$ & $3,09 \mathrm{~ns}$ & $2,53 \mathrm{~ns}$ \\
Período & $98,94^{*}$ & $72,34^{*}$ & $4,19 \mathrm{~ns}$ & $12,62^{\star}$ & $3,23 \mathrm{~ns}$ & $16,86 *$ & $3,28 \mathrm{~ns}$ \\
TxP & $25,84^{*}$ & $22,72^{*}$ & $0,48 \mathrm{~ns}$ & $2,14 \mathrm{~ns}$ & $0,58 \mathrm{~ns}$ & $2,20 \mathrm{~ns}$ & $2,12 \mathrm{~ns}$ \\
\hline
\end{tabular}

A cor aumentou gradativamente para o Controle, ficando mais amarelado em relação aos outros tratamentos durante o armazenamento. A ATM e o Vácuo mantiveram poucas variações de cor durante os 12 primeiros dias de armazenamento (Tabela 7). Comportamento parecido foi observado por Olarte et al (2000), no trabalho com queijo fresco de leite de cabra, em que o Controle ficou amarelado no $14^{\circ}$ dia de armazenamento, enquanto os demais tratamentos mantiveram a cor característica durante 28 dias (Tabela 7). 
Tabela 7. Médias e desvios padrões do atributo cor para o queijo Minas Frescal sob os três tratamentos (Controle, ATM e Vácuo) durante os 12 primeiros dias de armazenamento.

\begin{tabular}{cccc}
\hline Tratamento & \multicolumn{3}{c}{ Período (dias) } \\
\cline { 2 - 4 } & 5 & 8 & 12 \\
Controle & $1,56 \pm 0,40 \mathrm{Aa}$ & $3,40 \pm 0,44 \mathrm{Ba}$ & $6,02 \pm 0,36 \mathrm{Ca}$ \\
ATM & $1,58 \pm 0,29 \mathrm{Aa}$ & $1,73 \pm 0,30 \mathrm{Ab}$ & $1,91 \pm 0,43 \mathrm{Ab}$ \\
Vácuo & $1,42 \pm 0,39 \mathrm{Aa}$ & $1,56 \pm 0,43 \mathrm{Ab}$ & $2,05 \pm 0,37 \mathrm{Ab}$ \\
\hline
\end{tabular}

Nota: médias seguidas de letras distintas, maiúsculas nas linhas e minúsculas nas colunas, diferem entre si ao nível de $5 \%$ pelo teste de Tukey.

Após a rejeição do Controle, os queijos sob ATM e Vácuo mantiveram a mesma intensidade de cor até o $43^{\circ}$ dia de armazenamento para o ATM, e a partir do $36^{\circ}$ dia os queijos armazenados a Vácuo tornaram-se mais amarelados (Tabela 8).

Tabela 8. Médias e desvios padrões do atributo cor para os queijos sob ATM e Vácuo do $22^{\circ}$ ao $43^{\circ}$ dia de armazenamento.

\begin{tabular}{ccccc}
\hline Tratamento & \multicolumn{4}{c}{ Período (Dias) } \\
\cline { 2 - 5 } & 22 & 29 & 36 & 43 \\
ATM & $2,17 \pm 0,27 \mathrm{Aa}$ & $2,18 \pm 0,33 \mathrm{Aa}$ & $2,33 \pm 0,29 \mathrm{Aa}$ & $3,28 \pm 0,44 \mathrm{Aa}$ \\
Vácuo & $2,03 \pm 0,36 \mathrm{Aa}$ & $2,37 \pm 0,38 \mathrm{Aa}$ & $3,12 \pm 0,43 \mathrm{Aa}$ & $5,62 \pm 0,77 \mathrm{Bb}$ \\
\hline
\end{tabular}

Nota: médias seguidas de letras distintas, maiúsculas nas linhas e minúsculas nas colunas, diferem entre si ao nível de $5 \%$ pelo teste de Tukey. 
Assim, pelos resultados, pode-se caracterizar o queijo como um produto claro próximo ao branco. A mesma caracterização foi observada por Gurgel et al (2000). No presente trabalho, a ATM manteve esta coloração por 43 dias, o Vácuo por 36 dias e o Controle por apenas cinco dias (Tabela 7 e 8).

Os tratamentos a Vácuo e ATM mantiveram as características de frescor durante os 12 primeiros dias de armazenamento. Apenas o Controle diminuiu o frescor no $12^{\circ}$ dia, o qual diferiu dos demais tratamentos e períodos (Tabela 9).

Tabela 9. Médias e desvios padrões do atributo frescor sob os três tratamentos (ATM, Vácuo e Controle) durante os 12 primeiros dias de armazenamento.

\begin{tabular}{cccc}
\hline Tratamento & \multicolumn{3}{c}{ Período (dias) } \\
\cline { 2 - 4 } & 5 & 8 & 12 \\
Controle & $7,92 \pm 0,30 \mathrm{Aa}$ & $7,05 \pm 0,34 \mathrm{Aa}$ & $4,95 \pm 0,51 \mathrm{Ba}$ \\
ATM & $8,03 \pm 0,48 \mathrm{Aa}$ & $7,83 \pm 0,38 \mathrm{Aa}$ & $7,90 \pm 0,67 \mathrm{Ab}$ \\
Vácuo & $7,73 \pm 0,35 \mathrm{Aa}$ & $8,06 \pm 0,45 \mathrm{Aa}$ & $7,60 \pm 0,82 \mathrm{Ab}$ \\
\hline
\end{tabular}

Nota: médias seguidas de letras distintas, maiúsculas nas linhas e minúsculas nas colunas, diferem entre si ao nível de $5 \%$ pelo teste de Tukey.

O produto embalado em ATM manteve-se fresco durante os 43 dias de armazenamento, entretanto, no Vácuo o produto começou a perder a característica de fresco a partir do $43^{\circ}$ dia de armazenamento (Tabela 10).

Assim, o frescor manteve-se por 5 dias no Controle, e no queijo embalado a Vácuo foi conservado por um período de 22 dias. O tratamento sob ATM foi mais eficiente, mantendo o frescor por 43 dias de armazenamento (Tabelas 9 e 10). 
Tabela 10. Médias e desvios padrões do atributo frescor para os queijos sob ATM e Vácuo do $22^{\circ}$ ao $43^{\circ}$ dia de armazenamento.

\begin{tabular}{ccccc}
\hline Tratamento & \multicolumn{4}{c}{ Período (Dias) } \\
\cline { 2 - 5 } & 22 & 29 & 36 & 43 \\
ATM & $8,00 \pm 0,66 \mathrm{Aa}$ & $7,90 \pm 0,58 \mathrm{Aa}$ & $7,91 \pm 0,58 \mathrm{Aa}$ & $6,82 \pm 0,65 \mathrm{Aa}$ \\
Vácuo & $7,48 \pm 0,64 \mathrm{Aa}$ & $6,91 \pm 0,68 \mathrm{ABa}$ & $5,75 \pm 0,67 \mathrm{Bb}$ & $3,33 \pm 0,47 \mathrm{Cb}$ \\
\hline
\end{tabular}

Nota: médias seguidas de letras distintas, maiúsculas nas linhas e minúsculas nas colunas, diferem entre si ao nível de $5 \%$ pelo teste de Tukey.

Em relação à firmeza, pode-se concluir que o produto sob ATM foi o que obteve maior intensidade para esse atributo durante todo o período de armazenamento (Tabelas 11 e 13). A intensidade da firmeza foi diminuindo com o envelhecimento do queijo durante o armazenamento, sendo provavelmente devido à ação das enzimas proteolíticas e lipolíticas, as quais atuam sobre a proteína, diminuindo a firmeza do produto (Tabela 12). Tais resultados também foram observados por Gurgel (2000) em queijo Minas Frescal e Vosniakos \& Hatziionnou (1997). 
Tabela 11. Médias e desvios padrões do atributo firmeza para os três tratamentos (Controle, ATM e Vácuo) durante os 12 primeiros dias de armazenamento.

\begin{tabular}{cc}
\hline Tratamento & Média \\
\hline Controle & $6,02 \pm 1,20 \mathrm{~A}$ \\
ATM & $6,73 \pm 0,21 \mathrm{~B}$ \\
Vácuo & $6,06 \pm 0,62 \mathrm{~A}$ \\
\hline
\end{tabular}

Nota: médias seguidas de letras distintas diferem entre si ao nível de 5\% pelo teste de Tukey.

Tabela 12. Médias e desvios padrões do atributo firmeza para os queijos sob ATM e Vácuo durante os 12 primeiros dias de armazenamento.

\begin{tabular}{cc}
\hline Período (Dias) & Média \\
\hline 5 & $6,90 \pm 0,24 \mathrm{~A}$ \\
8 & $6,32 \pm 0,29 \mathrm{~B}$ \\
12 & $5,58 \pm 0,90 \mathrm{C}$ \\
\hline
\end{tabular}

Nota: médias seguidas de letras distintas diferem entre si ao nível de $5 \%$ pelo teste de Tukey. 
Tabela 13. Médias e desvios padrões do atributo firmeza para queijos sob ATM e Vácuo do $22^{\circ}$ ao $43^{\circ}$ dia de armazenamento.

\begin{tabular}{cc}
\hline Tratamento & Média \\
\hline ATM & $6,31 \pm 0,24 \mathrm{~A}$ \\
Vácuo & $4,32 \pm 0,41 \mathrm{~B}$ \\
\hline
\end{tabular}

Nota: médias seguidas de letras distintas diferem entre si ao nível de $5 \%$ pelo teste de Tukey.

A intensidade do brilho foi diminuindo para o Controle durante os doze primeiros dias de armazenamento, para a ATM e Vácuo manteve-se praticamente igual (Tabela 14). Para os queijos sob ATM verificou-se uma maior intensidade de brilho até o final do armazenamento (Tabela 15), sendo que este atributo também foi diminuindo com o envelhecimento do produto (Tabela 16), isso também foi observado por Silva et al (1980) em queijo fresco.

Tabela 14. Médias e desvios padrões do atributo brilho para os três tratamentos (Controle, ATM e Vácuo) durante os 12 primeiros dias de armazenamento.

\begin{tabular}{cccc}
\hline Tratamento & \multicolumn{3}{c}{ Período (dias) } \\
\cline { 2 - 4 } Controle & $5,86 \pm 0,49 \mathrm{Aa}$ & $5,11 \pm 0,54 \mathrm{Aa}$ & $3,46 \pm 0,39 \mathrm{Ba}$ \\
ATM & $5,78 \pm 0,59 \mathrm{Aa}$ & $5,18 \pm 1,18 \mathrm{Aa}$ & $5,50 \pm 0,46 \mathrm{Ab}$ \\
Vácuo & $5,95 \pm 0,80 \mathrm{Aa}$ & $5,87 \pm 0,77 \mathrm{Aa}$ & $5,20 \pm 0,52 \mathrm{Ab}$ \\
\hline
\end{tabular}

Nota: médias seguidas de letras distintas, maiúsculas nas linhas e minúsculas nas colunas, diferem entre si ao nível de $5 \%$ pelo teste de Tukey. 
Tabela 15. Médias e desvios padrões do atributo brilho para os queijos sob ATM e Vácuo do $22^{\circ}$ ao $43^{\circ}$ dia de armazenamento.

\begin{tabular}{cc}
\hline Tratamento & Média \\
\hline ATM & $5,11 \pm 0,36 \mathrm{a}$ \\
Vácuo & $4,04 \pm 0,61 \mathrm{~b}$ \\
\hline
\end{tabular}

Nota: médias seguidas de letras distintas diferem entre si ao nível de $5 \%$ pelo teste de Tukey.

Tabela 16. Médias e desvios padrões do atributo brilho para os queijos sob ATM e Vácuo do $22^{\circ}$ ao $43^{\circ}$ dia de armazenamento.

\begin{tabular}{cc}
\hline Período (Dias) & Média \\
\hline 22 & $5,50 \pm 0,38 \mathrm{a}$ \\
29 & $4,78 \pm 0,72 \mathrm{ab}$ \\
36 & $4,55 \pm 1,02 \mathrm{~b}$ \\
43 & $3,95 \pm 0,88 \mathrm{c}$ \\
\hline
\end{tabular}

Nota: médias seguidas de letras distintas diferem entre si ao nível de 5\% pelo teste de Tukey.

Houve um pequeno aumento da aeração durante os doze primeiros dias de armazenamento, provavelmente foi provocado por bactérias que ocasionam formação de bolhas (Tabela 17). 
Tabela 17. Médias e desvios padrões do atributo aerado para os queijos sob ATM e Vácuo dos 12 primeiros dias de armazenamento.

\begin{tabular}{cc}
\hline Período (Dias) & Média \\
\hline 5 & $1,90 \pm 0,10 \mathrm{a}$ \\
8 & $1,97 \pm 0,16 \mathrm{a}$ \\
12 & $2,58 \pm 0,28 \mathrm{~b}$ \\
\hline
\end{tabular}

Nota: médias seguidas de letras distintas diferem entre si ao nível de $5 \%$ pelo teste de Tukey.

Durante o armazenamento o soro aumentou gradativamente, isto também ocorreu no trabalho de Gurgel et al. (2000) com queijo Minas Frescal (Tabela 18 e 19).

Tabela 18. Médias e desvios padrões do atributo soroso dos queijos sob os três tratamentos (Controle, ATM e Vácuo) durante os 12 primeiros dias de armazenamento.

\begin{tabular}{cc}
\hline Período (Dias) & Média \\
\hline 5 & $1,01 \pm 0,02 \mathrm{a}$ \\
8 & $1,15 \pm 0,10 \mathrm{a}$ \\
12 & $1,48 \pm 0,07 \mathrm{~b}$ \\
\hline
\end{tabular}

Nota: médias seguidas de letras distintas diferem entre si ao nível de $5 \%$ pelo teste de Tukey. 
Tabela 19. Médias e desvios padrões do atributo soroso dos queijos sob ATM e Vácuo do $22^{\circ}$ ao $43^{\circ}$ dia de armazenamento.

\begin{tabular}{cc}
\hline Período (Dias) & Média \\
\hline 22 & $1,53 \pm 0,02 \mathrm{a}$ \\
29 & $1,59 \pm 0,08 \mathrm{ab}$ \\
36 & $1,92 \pm 0,14 \mathrm{~b}$ \\
43 & $2,42 \pm 0,41 \mathrm{c}$ \\
\hline
\end{tabular}

Nota: médias seguidas de letras distintas diferem entre si ao nível de $5 \%$ pelo teste de Tukey.

Os tratamentos ATM e Vácuo mantiveram a mesma intensidade de cremosidade durante todo o armazenamento, enquanto que o Controle apresentou aumento da intensidade deste atributo, o crescimento de microrganismos pode ter ocasionado essa perda na consistência, os quais atacam as proteínas mudando a textura do produto (Tabela 20).

Tabela 20. Médias e desvios padrões do atributo cremoso do queijo sob os três tratamentos (Controle, ATM e Vácuo) dos 12 primeiros dias de armazenamento.

\begin{tabular}{cccc}
\hline Tratamento & \multicolumn{3}{c}{ Período (dias) } \\
\cline { 2 - 4 } & 5 & 8 & 12 \\
Controle & $3,01 \pm 0,39 \mathrm{Aa}$ & $3,52 \pm 0,53 \mathrm{Aa}$ & $4,67 \pm 0,54 \mathrm{Ba}$ \\
ATM & $2,96 \pm 0,34 \mathrm{Aa}$ & $2,93 \pm 0,55 \mathrm{Aa}$ & $2,73 \pm 0,41 \mathrm{Ab}$ \\
Vácuo & $2,92 \pm 0,22 \mathrm{Aa}$ & $2,55 \pm 0,45 \mathrm{Aa}$ & $2,75 \pm 0,40 \mathrm{Ab}$ \\
\hline
\end{tabular}

Nota: médias seguidas de letras distintas, maiúsculas nas linhas e minúsculas nas colunas, diferem entre si ao nível de $5 \%$ pelo teste de Tukey. 


\subsubsection{Textura}

Comparando-se, a ATM, Controle e Vácuo, verificou-se que o valor F do atributo esfarelento foi significativo para o tratamento, período e interação entre período e tratamento. Os demais atributos, borrachudo e cremosidade, não apresentaram $F$ significativos para esses fatores, não influenciando na consistência do queijo Minas Frescal (Tabela 21).

Tabela 21. Valor F, obtido da análise de variância, para a textura do queijo Minas Frescal durante 12 primeiros dias de armazenamento.

\begin{tabular}{lllll}
\hline & \multicolumn{4}{c}{ Valor F } \\
\hline \multirow{3}{*}{ Tratamento } & Esfarelento & Consistência & Borrachudo & Cremoso \\
Período & $69,30^{*}$ & $1,05 \mathrm{~ns}$ & $4,27 \mathrm{~ns}$ & $0,04 \mathrm{~ns}$ \\
Tx P & $65,51^{*}$ & $8,94 \mathrm{~ns}$ & $3,03 \mathrm{~ns}$ & $2,28 \mathrm{~ns}$ \\
& $41,39^{*}$ & $1,37 \mathrm{~ns}$ & $3,49 \mathrm{~ns}$ & $0,32 \mathrm{~ns}$ \\
\hline
\end{tabular}

Do $22^{\circ}$ ao $43^{\circ}$ dia de armazenamento, os tratamentos sob ATM e Vácuo apresentaram valor $F$ significativo em relação aos atributos esfarelento e consistência, com interação entre período e tratamento. Os demais atributos (borrachudo e cremoso) não apresentaram valor F significativo (Tabela 22). 
Tabela 22. Valor F, obtido da análise de variância, para a textura do queijo Minas Frescal sob ATM e Vácuo do $22^{\circ}$ ao $43^{\circ}$ dia de armazenamento.

\begin{tabular}{lllll}
\hline & \multicolumn{4}{c}{ Valor F } \\
\hline \multirow{2}{*}{ Tratamento } & Esfarelento & Consistência & Borrachudo & Cremoso \\
Período & $108,25^{\star}$ & $14,18 \mathrm{~ns}$ & $14,98 \mathrm{~ns}$ & $5,61 \mathrm{~ns}$ \\
Tx P & $18,86^{\star}$ & $24,78^{\star}$ & $2,57 \mathrm{~ns}$ & $2,08 \mathrm{~ns}$ \\
\hline
\end{tabular}

A intensidade de esfarelamento aumentou para o Controle durante os doze primeiros dias de armazenamento, enquanto que os queijos embalados sob ATM não se alteraram durante todo o armazenamento em relação a esse atributo e para o vácuo houve um pequeno aumento a partir do $36^{\circ}$ dia de armazenamento (Tabelas 23 e 24).

Tabela 23. Médias e desvios padrões do atributo esfarelento para o queijo sob os três tratamentos (Controle, ATM e Vácuo) durante os 12 primeiros dias de armazenamento.

\begin{tabular}{cccc}
\hline Tratamento & \multicolumn{3}{c}{ Período (dias) } \\
\cline { 2 - 4 } & 5 & 8 & 12 \\
Controle & $4,80 \pm 0,53 \mathrm{Aa}$ & $5,16 \pm 0,44 \mathrm{Aa}$ & $7,92 \pm 0,47 \mathrm{Ba}$ \\
ATM & $4,66 \pm 0,52 \mathrm{Aa}$ & $4,77 \pm 0,52 \mathrm{Aa}$ & $4,83 \pm 0,53 \mathrm{Ab}$ \\
Vácuo & $4,65 \pm 0,59 \mathrm{Aa}$ & $4,75 \pm 0,60 \mathrm{Aa}$ & $5,08 \pm 0,63 \mathrm{Ab}$ \\
\hline
\end{tabular}

Nota: médias seguidas de letras distintas, maiúsculas nas linhas e minúsculas nas colunas, diferem entre si ao nível de $5 \%$ pelo teste de Tukey. 
O queijo sob ATM manteve a mesma nota de esfarelamento praticamente igual durante todo o armazenamento, e o queijo sob vácuo ficou mais esfarelado diferindo, da ATM no $36^{\circ}$ e $43^{\circ}$ dias de armazenamento (Tabela 24).

Tabela 24. Médias e desvios padrões do atributo esfarelento para os queijos sob ATM e Vácuo do $22^{\circ}$ ao $43^{\circ}$ dia de armazenamento.

\begin{tabular}{ccccc}
\hline Tratamento & \multicolumn{4}{c}{ Período (Dias) } \\
\cline { 2 - 5 } & 22 & 29 & 36 & 43 \\
ATM & $5,12 \pm 0,45 \mathrm{Aa}$ & $4,78 \pm 0,43 \mathrm{Aa}$ & $4,30 \pm 0,52 \mathrm{Aa}$ & $4,56 \pm 0,43 \mathrm{Aa}$ \\
Vácuo & $5,31 \pm 0,30 \mathrm{Aa}$ & $4,98 \pm 0,47 \mathrm{Aa}$ & $5,67 \pm 0,37 \mathrm{Ab}$ & $7,22 \pm 0,55 \mathrm{Bb}$
\end{tabular}

Nota: médias seguidas de letras distintas, maiúsculas nas linhas e minúsculas nas colunas, diferem entre si ao nível de $5 \%$ pelo teste de Tukey.

O produto sob ATM não alterou sua consistência durante todo o armazenamento, o Vácuo diminuiu a consistência, diferindo entre o período e o ATM a partir do $36^{\circ}$ dia de armazenamento (Tabela 25).

Pelos resultados, pode-se dizer que a consistência diminui gradativamente no Vácuo em relação a ATM. Este mesmo comportamento ocorreu no trabalho de Olarte et al. (2001), em que a ATM manteve as características iniciais de consistência por um período maior do que no Vácuo. 
Tabela 25. Médias e desvios padrões do atributo consistência para os queijos sob três tratamentos (Controle, ATM e Vácuo) do $22^{\circ}$ ao $43^{\circ}$ dia de armazenamento.

\begin{tabular}{ccccc} 
Tratamento & \multicolumn{4}{c}{ Período (Dias) } \\
\cline { 2 - 5 } & 22 & 29 & 36 & 43 \\
ATM & $5,37 \pm 0,45 \mathrm{Aa}$ & $4,95 \pm 0,55 \mathrm{Aa}$ & $4,90 \pm 0,68 \mathrm{Aa}$ & $4,90 \pm 0,46 \mathrm{Aa}$ \\
Vácuo & $5,35 \pm 0,51 \mathrm{Aa}$ & $5,67 \pm 0,66 \mathrm{Aa}$ & $3,88 \pm 0,57 \mathrm{Ba}$ & $3,23 \pm 0,84 \mathrm{Ba}$
\end{tabular}

Nota: médias seguidas de letras distintas, maiúsculas nas linhas e minúsculas nas colunas, diferem entre si ao nível de $5 \%$ pelo teste de Tukey.

\subsubsection{Sabor}

O valor $\mathrm{F}$ dos atributos azedo, amargo, característico, salgado e estranho foram significativos para todos os fatores: tratamento, período e interação entre período e tratamento. Somente o doce não apresentou $F$ significativo (Tabela 26).

Tabela 26. Valor $F$, obtido da análise de variância, para o sabor do queijo Minas Frescal sob os três tratamentos (Controle, ATM e Vácuo) durante os 12 primeiros dias de armazenamento.

\begin{tabular}{ccccccc}
\hline & \multicolumn{6}{c}{ Valor F } \\
\hline & Azedo & Amargo & Característico & Salgado & Doce & Estranho \\
Tratamento & $75,28^{\star}$ & $20,08^{*}$ & $16,98^{*}$ & $18,74^{\star}$ & $8,74 \mathrm{~ns}$ & $86,39^{\star}$ \\
Período & $145,84^{*}$ & $84,13^{\star}$ & $88,89^{*}$ & $18,31^{*}$ & $7,17 \mathrm{~ns}$ & $181,87^{\star}$ \\
TxP & $110,62^{*}$ & $23,76^{\star}$ & $25,48^{*}$ & $11,84^{\star}$ & $2,78 \mathrm{~ns}$ & $82,22^{*}$ \\
\hline
\end{tabular}


Após a rejeição do Controle, comparou-se a ATM e Vácuo do $22^{\circ}$ ao $43^{\circ}$ dia de armazenamento, onde os valores de $F$ dos atributos, azedo, característico e estranho foram significativos para tratamento, período e interação período e tratamento, e o amargo apresentou significância para interação entre período e tratamento. Os demais atributos (salgado e doce) não apresentaram valor F significativo (Tabela 27).

Tabela 27. Valor F, obtido da análise de variância, para o sabor do queijo Minas Frescal sob ATM e Vácuo do $22^{\circ}$ ao $43^{\circ}$ dia de armazenamento.

\begin{tabular}{ccccccc}
\hline & \multicolumn{6}{c}{ Valor F } \\
\hline & Azedo & Amargo & Característico & Salgado & Doce & Estranho \\
Tratamento & $23,63^{\star}$ & $27,76^{*}$ & $64,29^{*}$ & $0,18 \mathrm{~ns}$ & $7,10 \mathrm{~ns}$ & $208,71^{\star}$ \\
Período & $41,14^{\star}$ & $10,24^{\star}$ & $35,45^{\star}$ & $1,21 \mathrm{~ns}$ & $4,80 \mathrm{~ns}$ & $150,84^{\star}$ \\
Tx P & $24,78^{\star}$ & $5,54 \mathrm{~ns}$ & $27,22^{*}$ & $3,44 \mathrm{~ns}$ & $1,17 \mathrm{~ns}$ & $70,67^{\star}$ \\
\hline
\end{tabular}

O Controle apresentou um forte sabor azedo no $12^{\circ}$ dia de armazenamento, enquanto que os demais tratamentos não apresentaram grande intensidade deste atributo durante os doze primeiros dias de armazenamento (Tabela 28), o mesmo ocorreu nos trabalhos de Scott et al (1991) com queijo fresco e Juric et al (2003) com queijos semi duros. Após a rejeição do Controle este sabor foi detectado no queijo sob Vácuo a partir do $43^{\circ}$ dia, enquanto que o queijo sob ATM manteve baixa intensidade do sabor azedo durante todo armazenamento (Tabela 29). A presença de sabor azedo no produto pode ser devido à produção de ácidos pelas bactérias. 
Tabela 28. Médias e desvios padrões do atributo azedo para os queijos sob os três tratamentos (Controle, ATM e Vácuo) dos 12 primeiros dias de armazenamento.

\begin{tabular}{cccc}
\hline Tratamento & \multicolumn{3}{c}{ Período (dias) } \\
\cline { 2 - 4 } & 5 & \multicolumn{1}{c}{8} & 12 \\
Controle & $1,40 \pm 0,37 \mathrm{Aa}$ & $1,55 \pm 0,43 \mathrm{Aa}$ & $7,10 \pm 0,78 \mathrm{Ba}$ \\
ATM & $1,50 \pm 0,47 \mathrm{Aa}$ & $1,87 \pm 0,83 \mathrm{ABa}$ & $2,96 \pm 0,60 \mathrm{Bb}$ \\
Vácuo & $1,62 \pm 0,53 \mathrm{Aa}$ & $1,98 \pm 0,39 \mathrm{Aa}$ & $2,15 \pm 0,29 \mathrm{Ab}$ \\
\hline
\end{tabular}

Nota: médias seguidas de letras distintas, maiúsculas nas linhas e minúsculas nas colunas, diferem entre si ao nível de $5 \%$ pelo teste de Tukey.

Tabela 29. Médias e desvios padrões do atributo azedo para os queijos sob ATM e Vácuo dos $22^{\circ}$ ao $43^{\circ}$ dia de armazenamento.

\begin{tabular}{ccccc}
\hline Tratamento & \multicolumn{4}{c}{ Período (Dias) } \\
\cline { 2 - 5 } & 22 & 29 & 36 & 43 \\
ATM & $3,16 \pm 0,43 \mathrm{Aa}$ & $3,28 \pm 0,30 \mathrm{Aa}$ & $3,42 \pm 0,40 \mathrm{Aa}$ & $3,62 \pm 0,43 \mathrm{Aa}$ \\
Vácuo & $2,68 \pm 0,31 \mathrm{Aa}$ & $3,43 \pm 0,52 \mathrm{Aa}$ & $3,77 \pm 0,58 \mathrm{Aa}$ & $6,17 \pm 0,91 \mathrm{Bb}$ \\
\hline
\end{tabular}

Nota: médias seguidas de letras distintas, maiúsculas nas linhas e minúsculas nas colunas, diferem entre si ao nível de $5 \%$ pelo teste de Tukey.

O amargo apresentou característica similar ao sabor azedo, para o Controle no $12^{\circ}$ dia de armazenamento. Essa característica, juntamente com o azedo, foi prontamente observada pelos provadores no intervalo dos 8 aos 12 dias de armazenamento. Já no queijo sob ATM e Vácuo foi observado pouco sabor amargo durante os 12 primeiros dias de armazenamento (Tabela 30). Após a rejeição do Controle, verificou-se que o Vácuo apresentou uma maior 
intensidade de sabor amargo e com o envelhecimento do queijo este sabor se tornou mais intenso (Tabela 31 e 32).

Tabela 30. Médias e desvios padrões do atributo amargo para os três tratamentos durante os 12 primeiros dias de armazenamento.

\begin{tabular}{cccc}
\hline Tratamento & \multicolumn{3}{c}{ Período (dias) } \\
\cline { 2 - 4 } & 5 & 8 & 12 \\
Controle & $1,33 \pm 0,37 \mathrm{Aa}$ & $1,72 \pm 0,27 \mathrm{Aa}$ & $4,03 \pm 0,54 \mathrm{Ba}$ \\
ATM & $1,36 \pm 0,28 \mathrm{Aa}$ & $1,56 \pm 0,40 \mathrm{Aa}$ & $2,10 \pm 0,39 \mathrm{Ab}$ \\
Vácuo & $1,50 \pm 0,41 \mathrm{Aa}$ & $2,03 \pm 0,50 \mathrm{Aa}$ & $2,22 \pm 0,34 \mathrm{Ab}$ \\
\hline
\end{tabular}

Nota: médias seguidas de letras distintas, maiúsculas nas linhas e minúsculas nas colunas, diferem entre si ao nível de $5 \%$ pelo teste de Tukey.

Tabela 31. Médias e desvios padrões do atributo amargo para ATM e Vácuo do $22^{\circ}$ ao $43^{\circ}$ dia de armazenamento.

\begin{tabular}{cl}
\hline Tratamento & Média \\
\hline ATM & $2,68 \mathrm{a}$ \\
Vácuo & $3,40 \mathrm{~b}$ \\
\hline
\end{tabular}

Nota: médias seguidas de letras distintas diferem entre si ao nível de $5 \%$ pelo teste de Tukey. 
Tabela 32. Médias e desvios padrões do atributo amargo para os queijos sob ATM e Vácuo do $22^{\circ}$ ao $43^{\circ}$ dia de armazenamento.

\begin{tabular}{cc}
\hline Período (Dias) & Média \\
\hline 22 & $2,65 \pm 0,35 \mathrm{a}$ \\
29 & $2,90 \pm 0,16 \mathrm{a}$ \\
36 & $2,93 \pm 0,46 \mathrm{a}$ \\
43 & $3,68 \pm 0,69 \mathrm{~b}$ \\
\hline
\end{tabular}

Nota: médias seguidas de letras distintas diferem entre si ao nível de $5 \%$ pelo teste de Tukey.

O sabor característico manteve-se intenso para os tratamentos ATM e Vácuo, já para o Controle, a intensidade desse atributo foi diminuindo até o $12^{\circ}$ dia (Tabela 33). A perda do sabor característico também foi observada por Pintado et al. (2000) em requeijão e por Rodrigues et al. (1995) em queijo Minas Frescal. Após a rejeição do Controle, houve uma grande perda do sabor característico do produto embalado a Vácuo, enquanto que no produto embalado sob ATM esse sabor foi mantido até o final do período de armazenamento (Tabela 34).

O sabor característico do queijo Minas Frescal foi mantido por 43 dias no queijo sob ATM, sendo este o melhor tratamento para conservar este produto sensorialmente, pois o Controle apresentou alteração aos 12 dias e o Vácuo aos 29 dias de armazenamento (Tabela 32). 
Tabela 33. Médias e desvios padrões do atributo característico para os queijos sob os três tratamentos (Controle, ATM e Vácuo) durante os 12 primeiros dias de armazenamento.

\begin{tabular}{cccc}
\hline Tratamento & \multicolumn{3}{c}{ Período (dias) } \\
\cline { 2 - 4 } & 5 & 8 & 12 \\
Controle & $9,21 \pm 0,43 \mathrm{Aa}$ & $8,93 \pm 0,53 \mathrm{Aa}$ & $5,02 \pm 0,69 \mathrm{Ba}$ \\
ATM & $9,08 \pm 0,38 \mathrm{Aa}$ & $8,68 \pm 0,44 \mathrm{Aa}$ & $7,38 \pm 1,25 \mathrm{Ab}$ \\
Vácuo & $9,11 \pm 0,42 \mathrm{Aa}$ & $8,61 \pm 0,51 \mathrm{Aa}$ & $8,45 \pm 0,60 \mathrm{Ac}$ \\
\hline
\end{tabular}

Nota: médias seguidas de letras distintas, maiúsculas nas linhas e minúsculas nas colunas, diferem entre si ao nível de $5 \%$ pelo teste de Tukey.

Tabela 34. Médias e desvios padrões do atributo característico para os queijos sob ATM e Vácuo do $22^{\circ}$ ao $43^{\circ}$ dia de armazenamento.

\begin{tabular}{ccccc}
\hline Trat. & \multicolumn{4}{c}{ Período (Dias) } \\
\cline { 2 - 5 } & 22 & 29 & 36 & 43 \\
ATM & $7,15 \pm 1,34 \mathrm{Aa}$ & $7,75 \pm 0,67 \mathrm{Aa}$ & $7,63 \pm 0,77 \mathrm{Aa}$ & $6,91 \pm 0,60 \mathrm{Aa}$ \\
Vácuo & $8,05 \pm 0,75 \mathrm{Aa}$ & $6,92 \pm 1,23 \mathrm{ABa}$ & $4,97 \pm 0,56 \mathrm{ACa}$ & $2,82 \pm 0,51 \mathrm{Cb}$ \\
\hline
\end{tabular}

Nota: médias seguidas de letras distintas, maiúsculas nas linhas e minúsculas nas colunas, diferem entre si ao nível de $5 \%$ pelo teste de Tukey.

Para o Controle, o sabor salgado apresentou um pequeno aumento nos 12 primeiros dias de armazenamento, enquanto que a ATM e Vácuo mantiveram a mesma intensidade de sabor (Tabela 35). A perda de umidade do Controle pode ter influenciado no resultado a qual intensificou a concentração de sal no produto. 
Tabela 35. Médias e desvios padrões do atributo salgado para os três tratamentos (Controle, ATM e Vácuo) dos 12 primeiros dias de armazenamento.

\begin{tabular}{cccc}
\hline Tratamento & \multicolumn{3}{c}{ Período (dias) } \\
\cline { 2 - 4 } & 5 & 8 & 12 \\
Controle & $1,45 \pm 0,40 \mathrm{Aa}$ & $2,03 \pm 0,66 \mathrm{Aa}$ & $3,33 \pm 0,69 \mathrm{Ba}$ \\
ATM & $1,45 \pm 0,32 \mathrm{Aa}$ & $1,52 \pm 0,34 \mathrm{Aa}$ & $1,85 \pm 0,45 \mathrm{Ab}$ \\
Vácuo & $1,50 \pm 0,32 \mathrm{Aa}$ & $1,80 \pm 0,44 \mathrm{Aa}$ & $1,50 \pm 0,42 \mathrm{Ab}$ \\
\hline
\end{tabular}

Nota: médias seguidas de letras distintas, maiúsculas nas linhas e minúsculas nas colunas, diferem entre si ao nível de $5 \%$ pelo teste de Tukey.

No Controle foi detectado um intenso sabor estranho no $12^{\circ}$ dia sendo assim rejeitado este produto, esse sabor também foi verificado por Olarte et al. (2000) em queijo de cabra. Já para o queijo armazenado sob Vácuo este sabor só foi intenso no $36^{\circ}$ dia e os queijos sob ATM apresentaram baixa intensidade deste sabor durante todo o armazenamento. Assim pode-se afirmar que o queijo sob ATM manteve todas as características iniciais de sabor por 43 dias de armazenamento, sendo esse considerado o melhor tratamento para manter as características sensoriais do produto (Tabela 36 e 37 ). 
Tabela 36. Médias e desvios padrões do atributo estranho para os queijos sob os três tratamentos (Controle, ATM e Vácuo) dos 12 primeiros dias de armazenamento.

\begin{tabular}{cccc}
\hline Tratamento & \multicolumn{3}{c}{ Período (dias) } \\
\cline { 2 - 4 } & 5 & 8 & 12 \\
Controle & $0,86 \pm 0,33 \mathrm{Aa}$ & $1,46 \pm 0,45 \mathrm{Aa}$ & $7,11 \pm 0,81 \mathrm{Ba}$ \\
ATM & $0,88 \pm 0,37 \mathrm{Aa}$ & $1,22 \pm 0,26 \mathrm{Aa}$ & $2,12 \pm 0,86 \mathrm{Ab}$ \\
Vácuo & $0,92 \pm 0,33 \mathrm{Aa}$ & $1,41 \pm 0,64 \mathrm{Aa}$ & $1,72 \pm 0,45 \mathrm{Ab}$ \\
\hline
\end{tabular}

Nota: médias seguidas de letras distintas, maiúsculas nas linhas e minúsculas nas colunas, diferem entre si ao nível de $5 \%$ pelo teste de Tukey.

Tabela 37. Médias e desvios padrões do atributo estranho para os queijos sob ATM e Vácuo do $22^{\circ}$ ao $43^{\circ}$ dia de armazenamento.

\begin{tabular}{ccccc}
\hline Tratamento & \multicolumn{4}{c}{ Período (Dias) } \\
\cline { 2 - 5 } & 22 & 29 & 36 & 43 \\
ATM & $2,15 \pm 0,56 \mathrm{Aa}$ & $2,37 \pm 0,69 \mathrm{Aa}$ & $2,80 \pm 0,68 \mathrm{Aa}$ & $3,43 \pm 0,58 \mathrm{Aa}$ \\
Vácuo & $2,37 \pm 0,62 \mathrm{Aa}$ & $2,73 \pm 0,43 \mathrm{Aa}$ & $5,13 \pm 0,67 \mathrm{Bb}$ & $8,88 \pm 0,41 \mathrm{Cb}$ \\
\hline
\end{tabular}

Nota: médias seguidas de letras distintas, maiúsculas nas linhas e minúsculas nas colunas, diferem entre si ao nível de $5 \%$ pelo teste de Tukey. 


\section{CONCLUSÕES}

- O uso da ATM e Vácuo estabilizaram a população de mesófilos aeróbios totais a partir do $13^{\circ}$ dia de armazenamento a $4^{\circ} \mathrm{C}$, enquanto que, no Controle, esta população proliferou continuamente até o final do armazenamento.

- Os tratamentos (ATM e Vácuo) foram eficazes sobre a população de psicrotróficos aeróbios, estabilizando sua população nos queijos a partir da segunda semana.

- ATM e Vácuo não inibiram a população de bactérias psicrotróficas anaeróbias presentes nos queijos.

- O tratamento Vácuo reduziu em um ciclo logarítmico a população de Staphylococcus coagulase positiva e a ATM reduziu 0,5 ciclos logarítmico desta população, durante o período de armazenamento das amostras de queijo.

- Os tratamentos utilizados não foram eficientes sobre as populações de coliformes totais e Escherichia coli presentes nos queijos, pois estas proliferaram continuamente até o $21^{\circ}$ dia de armazenamento.

- Os tratamentos ATM e Vácuo mantiveram aceitação sensorial dos queijos por 40 dias, enquanto que o Controle foi rejeitado no $17^{\circ}$ dia de armazenamento.

- A irradiação do queijo Minas Frescal com 2 KGy reduziu todas as populações de bactérias estudadas. 
- A irradiação com 2 KGy foi mais eficiente nos queijos embalados sob ar atmosférico, contudo durante o armazenamento as populações de mesófilos e psicrotróficos aeróbios recuperaram-se, atingindo contagens superiores as iniciais antes da irradiação, em 26 dias.

- Os tratamentos ATM e Vácuo após a irradiação, inibiram a população de mesófilos aeróbios e psicrotróficos aeróbios nos queijos armazenados.

- Os tratamentos ATM e Vácuo mais irradiação não foram eficazes sobre a população de microrganismos psicrotróficos anaeróbios.

- A irradiação do queijo com 2 KGy foi muito eficaz sobre a população de Staphylococcus coagulase positiva.

- Os tratamentos utilizados, após a irradiação, foram eficazes sobre as populações de coliformes totais e Escherichia coli, havendo declínio destas durante todo o armazenamento.

- Segundo as características sensoriais, após a irradiação do produto, o tratamento ATM foi o melhor, pois este manteve a aparência, textura e sabor por 43 dias, o Vácuo por 36 dias e o Controle por apenas 8 dias.

- A utilização da irradiação com atmosfera modificada juntamente com baixas temperaturas de armazenamento aumentaram a vida útil do queijo, impedindo o desenvolvimento microbiano no produto e mantendo as características sensoriais. 


\section{REFERÊNCIAS BIBLIOGRÁFICAS}

\section{ASSOCIATION OF OFFICIAL ANALYTICAL CHEMISTY (AOAC). Official}

methods of analysis. 16.ed. Arlington, 1995. 2v.

ABDEL BAKY, A.A.; FARAHAT, S.M.; RABIE, A.M. et al. The manufacture of ras cheese from gamma irradied milk. Food Chemistry, v.20, n.10, p.201-212, 1986.

ADAMS, D.M.; BARACH, J.T.; SPECK, M.L. Heat resistant proteases in milk by psychrotrophic bacteria of dairy origin. Journal of Dairy Science, v.58, n.6, p.828-834, Dec. 1974.

ADAMS, D.M.; BRAWLEY, T.G. Heat resistant bacterial lipases and ultra-high temperature sterilization of dairy products. Journal of Dairy Science, v.64, n.10, p.1951-1957, Oct. 1981.

AHMED, A.A.H.; MOUSTAFA, M.K.; M.K.; MARTH, E.H. Incidence of Bacillus cereus in milk and some milk products. Journal of Food Protection, v.46, n.2, p.126-128, Feb.1983.

ALMEIDA FILHO, E.S.; NADER FILHO, A. Ocorrência de Staphylococcus aureus em queijo tipo frescal. Revista de Saúde Pública, v.34, n.6, p.25-29, dez. 2000. 
ALVES, R.M.V.; SARANTÓPOULOS, C.; VAN DENDER, A.G.F. et al. Stability of sliced mozzarella cheese in modified atmosphere packaging. Journal of Food Protection, v.59, n.8, p.838-844, 1996.

ANDERSON, R.E; HEDLUND, C.B.; JONSSON, U. Thermal inactivation of a heat-resistant lipase produced by the psychritrophic bacterium Pseudomonas fluorescens. Journal of Dairy Science, v.62, n.3, p.361-367, Mar. 1979.

BEHMER, M.L.A. Tecnologia de leite. 13.ed. São Paulo: Nobel, 1984. 250p.

BISHOP, J.R.; WHITE, C.H. Assessment of dairy product quality and potential shelf life: a review. Journal of Food Protection, v.49, n.9, p.739-753, Sept. 1986.

BONASSI, J.A. Influência de algumas espécies de bactérias lácticas na elaboração do queijo tipo Minas. Botucatu, 1979. 133p. Tese (Livre-Docência) - Faculdade de Ciências Agronômicas, Universidade Estadual Paulista "Júlio de Mesquita Filho".

BORELLI, B.M.; LACERDA, I.C.A.; FERREIRA, E.G.; DIAS, R.S. et al. Perfil microbiológico de queijo Minas curado produzido na região da Serra da Canastra-MG. In: CONGRESSO BRASILEIRO DE CIÊNCIA E TECNOLOGIA DE ALIMENTOS, 17., Fortaleza, 2000. Anais. Fortaleza: SBCTA, 2000. p.4.91.

BOUGLE, D.L.; STAHL, V. Survival of Listeria monocytogenes after irradiation treatment of camembert cheeses made from raw milk. Journal of Food Protection, v.57, n.9, p.811-813, 1994b. 
BOUGLE, D.L.; STAHL, V. Survival of Listeria monocytogenes after irradiation treatment of Cammembert cheeses made. Journal of Food Protection, v.29, n.57, p.811-813, 1994a.

BOURGEOIS, C.M.; MESCLE, J.F.; ZUCCA, J. Microbiologia alimentaria. Zaragoza: Acribia, 1994. 437p.

BRASIL. Ministério da Agricultura e do Abastecimento. Portaria $n^{\circ} 2244$ de 04 de julho de 1997. Nova legislação de produtos lácteos e de alimentos para fins especiais, diet, light e enriquecidos. São Paulo: Fonte Comunicações, 1998. 76p. Aprova regulamento técnico de identidade dos queijos.

BRASIL. Ministério da Agricultura e do Abastecimento. Agência Nacional de Vigilância Sanitária (ANVISA). Resolução no 12 de 02 de janeiro de 2001. Diário Oficial da União, n.7, jan. 2001. Seção 1, p.45-53. Aprova os padrões microbiológicos sanitários de diferentes grupos de produtos alimentícios para fins de registro e fiscalização.

BRASIL. Ministério da Agricultura e do Abastecimento. Laboratório de Referência Nacional (LANARA). Métodos analíticos oficiais para o controle de produtos de origem animal e seus ingredientes: I. Métodos microbiológicos II. Métodos físicos e químicos. Brasília, 1981. 510p.

BRECHT, P. Use of controlled atmospheres to retard deterioration of produce. Food Technology, v.34, n.3, p.45-50, 1980.

BRODY, A.L. The market. In: PARRY, R.T. Principles and applications of modified atmosphere packaging of food. London: Blackie Academic \& Professional, 1993. cap.2, p.19-40. 
BRYAN, F.L. Microbiological food hazards today: based on epedemiological information. Food Tecnology, v.28, n.9, p.52-84. Sept. 1974.

BRYAN, F.L. Risks associed with vehicles of foodborne pathogenes and toxins. Journal of Food Protection, v.51, n.6, p.498-508, June 1988.

BUCHANAN, R.E.; GIBBONS, R.E. (Ed.). Bergey's manual of determinative bacteriology. 8.ed. Balimore: Willians e Wilkins, 1994. 1268p.

CALCI, K.R.; BURKHARDT III, W.; WATKINS, W.D. Occurrence of male especific bacteriophage in fecal and domestic animal wastes, human feces and human associated wastewaters. Applied and Environmental Microbiology, v.64, n.12, p.5027-5029, Dec. 1998.

CARMO, L.S.; DIAS, R.S.; ANUNCIAÇÃO, L.L.C. et al. Staphylococcal food poisoning in Minas Gerais State, Brasil. Arquivo Brasileiro de Medicina Veterinária e Zootecnia, v.47, n.2, p.133-122. 1995.

CARVALHO, E.P. Microbiologia de alimentos. Lavras: UFLA/FAEPE, 1999. 76p. (Curso de especialização pós-graduação "lato sensu" ensino à distancia: processamento e controle de qualidade em carne, leite, ovos e pescado)

CARVALHO, E.P.; MOCHEL, A.C.; LEAL, D.D.M. et al. Qualidade de queijo Minas Frescal comercializado em feiras livres. In: CONGRESSO NACIONAL DE LATICÍNIOS, 14., Juiz de Fora, 1996. Anais. Juiz de Fora: EPAMIG, 1996. p.111-118. 
CASAGRANDE, H.R.; WOLFSCHONN-POMBO, A.F. Fermentação da lactose no queijo Minas Frescal. Revista do Instituto de Laticínios Cândido Tostes, v.267-272, n.45, p.38-52, 1990.

CECHI, L.; BRASCA, M.; LODI, R. et al. Irradidation of dairy products: sensitivity of different microorganisms. Latte, v.8, n.8, p.84-92, 1996.

CERQUEIRA, M.M.O.P.; SOUZA, M.R.; FONSECA, R.E. et al. Surto epidêmico de toxinfecção alimentar envolvendo queijo Minas Frescal em Pará de Minas/MG. In: CONGRESSO NACIONAL DE LATICÍNIOS, 8., Juiz de Fora, 1995. Anais. Juiz de Fora: EPAMIG, 1995. p.233-235.

CHAVES, J.B.P. A análise sensorial na indústria de laticínios. Revista do Instituto de Laticínio Cândido Tostes, v.45, n.267/272, p.38-52, 1990.

CHAVES, J.B.P. Métodos de diferença em avaliação sensorial de alimentos e bebidas. Viçosa: Editora da UFV, 1993. 91p.

CHEN, J.H.; HOTCHKISS, J.H. Effect of dissolved carbon dioxide on the growth of psychrotrophic organisms in Cottage cheese. Journal of Dairy Science, v.74, n.9, p.2941-2945, 1991.

CHEN, J.H.; HOTCHKISS, J.H. Growth of Listeria monocytogenes and Clostridium sporogenes in cottage cheese in modified atmosphere packaging. Journal of Dairy Science, v.76, n.4, p.972-977, 1993.

CHORDASH, R.A.; POTTER, N.N. Stability of staphylococcal enterotoxin a to selected conditions encountered in food. Journal of Food Science, v.41, n.4, p.906-909, July/Aug. 1976. 
CHURCH, I.J; PARSONS, A.L. Modified atmosphere packaging technology: a review. Journal Science Food Agriculture, v.67, p.143-152, 1995.

CHURCH, P.N. Meat products. In: PARRY, R.T. Principles and applications of modified atmosphere packaging of food. London: Blackie Academic \& Professional, 1993. cap.10, p.229-268.

COLEN, G.; PEREIRA, M.L.; CARMO, L.S. et al. Avaliação microbiológica do leite tipo C e queijo tipo "Minas" comercializado em Belo Horizonte. In: CONGRESSO NACIONAL DE LATICÍNIOS, 7., Juiz de Fora, 1993. Anais. Juiz de Fora: EPAMIG, 1996. p.1984.

COUSIN, M.A.; JAY, M.J.; VASAVADA, P.C. Pshychorotrophic microorganisms. In: VANDERZANT, C.; SPLITTSTOESSER, D.F. Compedium of methods for the microbiological examination of foods. 3.ed. Washington: American Public Health Association (APHA), 1992. 340p.

DAMÁSIO, M.H.; COSTELL, E. Analisis sensorial descriptiva: generacion de descriptors y selecion de catadores. Revista Agroquímica Tecnologica de Alimentos, v.31, n.2, p.165-178, 1991.

DANIELS, J.A.; KRISHNAMURTH, R.; RIZVI, S.S.H. A review of effects of carbon dioxide on microbial growth and food quality. Journal of Food Protection, v.48, n.6, p.532-537, June 1985.

DAY, B.P.F. Guidelines for the good manufacturing and handing of modified atmosphere packed food products. Gloucestershire: The Campden Food and Drink Research Association, 1992. 79p. (Technical Manual, 34) 
DIAS, R.S.; SILVA, S.O.; SOUZA, J.M. et al. Surtos de toxinfecção alimentar provocados por queijos comercializados em Minas Gerais, no período de 1992 a 1994. In: CONGRESSO NACIONAL DE LATICÍNIOS, 8., Juiz de Fora, 1995. Anais. Juiz de Fora: EPAMIG, 1995. p.143-144.

DIEHL, J.F. Safety of irradiated foods. 2.ed. New York: Marcel Dekker, 1996. $297 p$.

DUTCOSKY, S.D. Análise sensorial de alimentos. Curitiba: Editora Universitária Champagnat, 1996. 123p.

EIFERT, J.D.; GENNINGS, C.; CARTER JUNIOR, L. et al. Predicative model with improved statistical analysis of interative factors affecting the growth of Staphylococcus aureus. Journal of Food Protection, v.59, n.6, p.608-614, June 1996.

EL-BATAWAY, M.A.; EWAIS, S.M.; IBRAHIM, M.K.E. Shelf life of Kareish cheese as affected by gamma-irradiation. Egyptian Journal of Dairy Science, v.16, n.1 p.99-105, 1988. /Resumo em Food Science and Technology Abstract, 1988/

ELIOT, S.C.; VUILLEMARD, J.C.; EMOND, J.P. Estability of shredded mozzarella cheese under modified atmospheres. Journal of Food Science, v.63, n.6, p.1075-1080, 1998.

EWAIS, S.M.; EL-BATAWY, M.A.; IBRAHIM, M.K. Utilization of gamma irradiation to control Egyptian blue mould cheese ripening. Egyptian Journal of Dairy Science, v.17, n.2, p.317-326, 1990. /Resumo n.5331 em Dairy Science Abstract, v.52. n.7, p.598, 1990/ 
FABER, J.M. Microbiological aspects of modified: atmosphere packing technology: a review. Journal of Food Protection, v.54, n.1, p.58-70. 1990.

FANDOS, E.; SANZ, S.; OLARTE, C. Microbiological, physicochemical and sensory characteristics of Cameros cheese packeged under modified atmospheres. Food Microbiology, v.17, n.10, p.407-414, 2000.

FAO. Summary information on the role of international fishery and other bodies with regard to the conservation and management of living resources of the high seas. Roma, 1996. 104p.

FAO. International Organization of Energy Atomic; ORGANIZACION MUNDIAL DE LA SALUD (OMS). Bases tecnicas para la legislacion referente a los alimentos irradiados. Roma,1966. 62p.

FARKAS, J. Irradiation as a method for decontaminating food: a review. International Journal of Food Microbiology, v.51, n.44, p.189-204, 1998.

FARRAG, S.A.; MARTH, E.H. Growth of Listeria monocytogenes in the presence of Pseudomonas fluorescens at 7 or $13^{\circ} \mathrm{C}$ in skim milk. Journal of Food Protection, v.52, n.12, p.852-855, Dec. 1989.

FEITOSA, T. Aspecto higiênico e sanitário do queijo tipo Coalho do estado do Ceará. Ciência Agronômica, v.16, n.2, p.27-32, Dez. 1985.

FELÍCIO FILHO, A. Eficiência econômica de estocagem de queijos. Informe Agrupecuário, v.10, n.21, p.6-11, 1984.

FRANCO, B.D.G.M.; LANDGRAF, M. Microbiologia dos alimentos. São Paulo: Atheneu, 1996. 182p. 
FURTADO, M.M.; LOURENÇO NETO, J.P.M. Tecnologia de queijos: manual técnico para produção de industrial de queijos. São Paulo: Dipamar, 1994. $112 p$.

FURTADO, M.M. Principais problemas dos queijos: causas e prevenção. São Paulo: Fonte Comunicações, 1999. 176p.

FURTADO, M.M.; LOURENÇO NETO, J.P.M.; WOLSFSCHOON-POMBO, A.F. Estudo exclusivo a respeito da fabricação do queijo Minas frescal por diferentes processos. Revista do Instituto de Laticínios Cândido Tostes, v.208, n.35, p.13-16,1980.

GERMANO, P.M.L.; GERMANO, M.I.S. Higiene e vigilância sanitária de alimentos. São Paulo: Varela, 2001. 630p.

GODOY, R. Atmosfera modificada: conservação natural dos alimentos. Revista Nacional da Carne, v.1995, n.223, p.54-61, 1995.

GOMES, H.A.; GALLO, C.R. Ocorrência de Staphylococcus aureus e produção de enterotoxinas por linhagens isoladas a partir de leite cru, leite pasteurizado tipo "C" e queijo "Minas frescal" comercializados em Piracicaba - SP. Ciência e Tecnologia de Alimentos, v.15, n.2, p.158-161, 1995.

GURGEL, M.S.C.C.A. Efeito da radiação gama na resistência aos Staphylococcus aureus (Rosembach, 1884) e nas propriedades físicoquímicas e sensoriais do queijo Minas Frescal. Piracicaba, 2000. 81p. Tese (Doutorado) - Centro de Energia Nuclear na Agricultura, Universidade de São Paulo. 
GUTIERREZ, E.M.R. Efeito da radiação gama na maturação do queijo prato. Piracicaba, 2001. 115p. Tese (Doutorado) - Centro de Energia Nuclear na Agricultura, Universidade de São Paulo.

HARPER, R. Control of food quality and food analysis. London: Elsevier, 1984. cap.4, p.181-202: Sensory quality control.

HASHISAKA, A.E.; MATCHES, J.R.; BATTERS, Y. et al. Effects of gamma irradiation at $-78^{\circ} \mathrm{C}$ on microbial populations in dairy products. Journal of Food Science, v.55, n.5, p.1284-1289, 1990.

HASHISAKA, A.E.; WEAGANT, S.D.; DONG, F.M. Survival of Listeria monocytogenes in mozzarella cheese and ice cream exposed to gamma irradiation. Journal of Food Protection, v.52, n.7, p.490-492, 1989.

HATAKKA, M.; BJORKROTH, K.J.; ASPLUND, K. et al. Genotypes and enterotoxicity of Staphylococcus aureus isolated from the hands and nasal cavities of flight-catering employees. Journal of Food Protection, v.63, n.11, p.1487-1491, Nov. 2000.

HAYES, P.R. Microbiología e higiene de los alimentos. Zaragoza: Acribia, 1993. 369p.

HOBBS, B.C.; ROBERTS, D. Higiene y toxicología de los alimentos. 3.ed. Zaragoza: Acribia, 1997. 478p.

HOLT, J.G.; KRIEG, N.R.; SNEATH, O.H.A. et al. Bergey's manual of determinative bacteriology. Baltimore: Williams and Wikins, 1994. 787p. 
HURST, A.; HUGHES, A. The protective effect of some food ingredients on Staphylococcus aureus. Journal of Applied Bacteriology, v.55, n.1, p.8188, Aug. 1983.

IBRAHIM, M.K.; EL-BATAWAY, M.A.; EWAIS, S.M. Changes in some microbiological properties of Ras cheese during ripening as affected by gamma irradiation. Egyptian Journal of Dairy Science, v.15, n.1, p.161168, 1987. /Resumo em Food Science and Technology Abstract/

INTERNATIONAL COMMISSION ON MICROBIOLOGICAL SPECIFICATIONS FOR FOODS (ICMFS). Microrganismos de los alimentos: técnicas de análisis microbiológico. 2.ed. Zaragoza: Acribia, 1983. 606p.

INTERNATIONAL COMMISSION ON MICROBIOLOGICAL SPECIFICATIONS FOR FOODS (ICMFS). Microrganismos de los alimentos: características de los patógenos microbianos. Zaragoza: Acribia, 1998. v.1. 431p.

ISEPON, J.S.; OLIVEIRA, A.J. Influencia do emprego de culturas lácteas nas características do queijo tipo Minas Frescal. Ciência e Tecnologia de Alimentos, v.15, n.1, p.1-5, 1995.

JARRET, R.D. Isotope (gamma) radiation sources. In: JOSEPHSON, E.S.; PETERSON, M.S. Preservation of food by ionizing radiation. Boca Raton: CRC Press, 1987. v.1, cap.3, p.137-163.

JAY, J.M. Microbiologia moderna de los alimentos. 3.ed. Zaragoza: Acribia, 1994. 580p. 
JOMES, T.H.; JELEN, P. Low dose gamma-irradiation of Camembert, Cottage cheese and Cottage cheese whey. Milchwissenschaft, v.43, n.4, p.233-235, 1988.

JURIC, M.; BERTELSEN, G.; MORTENSEN, G.; PETERSEN, M. Light-induced colour and aroma changes in sliced, modified atmosphere packaged semihard cheeses. International Dairy Journal, v.13, n.4, p.239-249, 2003.

KADER, A.A. Prevention of ripening in fruits by use of controlled atmospheres. Food Tecnhology, v.34, n.3, p.51-54, 1980.

KING, A.D.; NAGEL, C.W. Influence of carbon dioxide upon the metabolism of Pseudomonas aeroginosa. Journal of Food Science, v.40, n.21, p.362-366, 1975.

KOSIKOWSKI, F.V.; BROWN, D.P. Influence of carbon dioxide and nitrogen on microbial populations and shelf life of cottage cheese and sour cream. Journal of Dairy Science, v.56, n.1, p.13-18, 1973.

KRCAL, Z.; PREKOPPOVA, J.; SLOTTOVA, P.T. Possibility of using ionizing radiation for extending the storage life of Brydza. Prumysl-Potravin, v.29, n.12, p.689-690, 1978. /Resumo em Food Science and Technology Abstract/

LAICINI, Z.M. Avaliação dos laudos analíticos das amostras de alguns tipos de queijo recebidos de Ribeirão Preto. Revista do Instituto Adolfo Lutz, v.53, n.53, p.17-20, 1993.

LALAGUMA, F. Physicochemical reponse of Palmita cheese to low dose irradiation. Journal of Food Science, n.68, v.1, p.26-30. 2003. 
LAMB, J.L.; GOGLEY, J.M.; THOMPSON, M.J. et al. Effect of low-dose gamma irradiation on Staphylococcus aureus and product packaging in ready-to-eat ham and cheese sandwiches. Journal of Food Protection, v.11, n.65, p.1800-1805, 2002.

LEITÃO, M.F.F. Fatores que afetam o desenvolvimento microbiano em alimentos. In: ROITMAN, I.; TRAVASSOS, L.R.; AZEVEDO, J.L. Tratado de microbiologia. São Paulo: Mamole, 1988. v.2. 214p.

LEITE BRASIL. Banco de dados: índices tabelas (produção brasileira de queijos comuns e especiais em esbabelecimento sob inspeção federal). http://www.leitebrasil.org.br (18 fev. 2003)

LEITE JUNIOR, A.F.S.; FLORENTINO, E.R.; OLIVEIRA, E.B. et al. Qualidade microbiológica de queijo coalho comercializado à temperatura ambiente ou sob refrigeração, em Campina Grande-PB. Higiene Alimentar, v.4, n.73, p.53-59, jun. 2000.

LIN, J.; SMITH, M.P.; CHAPIN. K.C. et al. Mechanisms of acid resistance in enterohemorrhagic Escherichia coli. Applied and Environmental Microbiology, v.62, n.9, p.3094-3100, Sept. 1996.

LÜCK, H. Control de la calidad de la industria lactológica. In: ROBISON, R.K. (Ed.). Microbiologia lactologica. Zaragoza: Acribia, 1987. v.2, cap.6, p.255-94.

LYON, D.H.; FRANCOMBE, M.A.; HASDELL, T.A. et al. Guidelines for sensory analysis in food products development and quality control. London: Chapman and Hall, 1992. 131p. 
MACKEY, B.M. The recovery of sublethally injured Escherichia coli from frozen meat. Journal of Applied Bacteriology, v.48, n.24, p.315-324, 1980.

MANDIL, A.; MORAIS, V.A.D.; PEREIRA, M.L. et al. Staphylococcus aureus em queijo tipo "Minas". Ciência e Tecnologia de Alimentos, v.2, n.23, p.233-241, 1982.

MANIAR, A.B.; JOSEPH, E.M.; BISHOP, J.R. et al. Modified atmosphere packaging to maintain direct-set cottage cheese quality. Journal of Food Science, v.59, n.6, p.1305-1308, 1994.

MANNHEIM, C.H.; SOFFER, T. Shelf life extension of cottage cheese by modified atmosphere packaging. Wissenchaft und Technologie, v.29, n.10, p.767-771, 1996.

MERCHANT, I.A. Veterinary bacteriology and viriology. 4.ed. Ames: The lowa College, 1950.

MOIR, C.J.; EYLES, M.J.; DAVEY, J.A. Inibition of pseudomonads in cottage cheese by packaging in atmospheres containing carbon dioxide. Food Microbiology, v.10, n.4, p.343-351, Aug. 1993.

MONK, J.D.; BEUCHAUT, L.R.; DOYLE, M.P. Irradiation inactivation of foodborne microorganisms. Journal of Food Protection, v.58, n.2, p.197-208,1995.

MONTEIRO, C.L.B. Técnicas de análise sensorial. 2.ed. Curitiba: Editora da Universidade Federal do Paraná,1984.101p. 
MORALES, A.A. La evaluación sensorial de los alimentos en la teoría y la práctica. Zaragoza: Acribia, 1997. 198p.

MORI. E.E.M. (Coord.). Métodos sensoriais e físicos para a avaliação de alimentos e bebidas: princípios e aplicações. Campinas: ITAL, 1992. 112p.

ODEGOV, I.; UMANSKII, M.S.; OSTROUMOV, L.A. Effect of ionizing radiation on microbiological processes in Rossiiski cheese. Milk and Dairy Products, v.25, n.34, p.336-338, 1974. /Resumo em Food Science and Technology Abstract on CD-ROM, 1969-95/

OLARTE, C.; GONZÁLEZ-FANDOS, E.; GIMÉNEZ, M. et al. The growth of Listeria monocytogenes in fresh goat cheese (Cameros cheese) packaged under modified atmospheres. Food Microbiology, v.19, n.19, p.75-82, 2002.

OLIVEIRA, C.A.F.; MORENO, J.F.G.; MESTIERI, L.; GERMANO, P. Características física-química e microbiológicas de queijo Minas frescal e Mussarela, produzidos em algumas fabricas de lacticínios do Estado de São Paulo. Higiene Alimentar, v.12, n.55, p.31-35, 1998.

OLIVEIRA, J.S. Queijo: fundamentos tecnológicos. São Paulo: Ícone; Campinas: Unicamp, 1986. p.105-114.

PARRY, R.T. Introduction. In: PARRY, R.T. Principles and applications of modified atmosphere packaging of food. London: Blackie Academic \& Professional, 1993. cap.1, p.1-18.

PATTERSON, M. Sensitivity of bactéria to irradiation on poultry meat under varies atmosphere. Letters in Applied Microbiology, v.7, n.3, p.55-58, 1998. 
PELCZAR, M.J.; CHAN, E.C.S.; KRIEG, N.R. Microbiologia: conceitos e aplicações. 2.ed. São Paulo: Makron Books do Brasil, 1997. v.1, 524p.

PELCZAR, M.J.; REID, R.; CHAN, E.C.S. Infecções humanas transmitidas pelos alimentos e água. Microbiologia. São Paulo: McGraw-hill, 1981. v.2, cap.29, p.696-697.

PEREIRA, M.L.; CARMO, L.S.; COLEN, G. et al. Avaliação das condições higiênico-sanitárias de queijos comercializados no município de Belo Horizonte, MG. 1987. In: ENCONTRO NACIONAL DE ANALISTAS DE ALIMENTOS, 3., Florianópolis, 1987. Anais. Florianópolis: UFSC, 1987. p.45-48.

PEREIRA, M.L.; LARA, M.A.; DIAS, R.S. Intoxicação por Staphylococcus aureus provocada por queijo tipo "Minas". Revista Microbiologia, v.22, n.29 p.22-27, 1996.

PEREIRA, M.L.; PEREIRA, J.L.; SERRANO, A.M. et al. Estafilococos e alimentos: possibilidades de disseminação através do portador humano e animal. Higiene Alimentar, v.13, n.66/67, p.48-55, nov. 1999.

PINTADO, M.E.; MALCATA, F.X. Optimization of modified atmosphere packaging with respect to physicochemical characteristics of Requeijão. Food Research International, v.33, n.39, p.821-832, 2000.

PINTO, P.S.A.; GERMANO, M.I.S.; GERMANO, P.M.L. Queijo minas: problema emergente de vigilância sanitária. Higiene Alimentar, v.10, n.44, p.22-27, 1996. 
PREGNOLATTO, W.; PREGNOLATTO, N. Normas analíticas do instituto Adolfo. São Paulo: Instituto Adolfo Lutz, 1985. 533p. v.1.

QUINTO, E.J.; FRANCO, C.M.; FENTE, C.A. et al. Growth of Escherichia coli O157: $\mathrm{H} 7$ in the presence of Pseudomonas fluorescens in skimmed milk at 7 or $25^{\circ} \mathrm{C}$. Journal of Food Safety, v.16, n.4, p.273-285, Apr. 1997.

RAIBNITZ, M.G.R.; TAVARES, L.B.B.; GARCÍA, J.A. Presencia de coliformes fecales, Escherichia coli y Staphylococcus aureus coagulasa y DNAsa positivos em queso. Revista Argentina de Microbiologia, v.30, n.1, p.8-12, 1998.

RAIMUND, S.M.C. Qualidade microbiológica do queijo "Minas frescal" no comércio do Rio de Janeiro. Revista do Instituto Cândido Tostes, v.47, n.52, p.169-173, 1992.

REINbOLD, G.W. Indicador organisms in dairy products. Food Technology, v.37, n.6, p.111-113, June 1983.

RIBEIRO, G.A.; ALEIXO, J.A.G.; LIMA, N.B.F. Ocorrência de Escherichia coli enteropatogênicas em produtos lácteos comercializados em Pelotas, RS. Boletim da Sociedade Brasileira de Ciência e Tecnologia de Alimentos, v.25, n.2, p.62, jul./dez. 1991.

RIBEIRO, M.G.; PINTO, J.P.A.N.; SILVA, E.O.T.R. Escherichia coli O157:H7 de hambúrguer, leite e outros gêneros alimentícios à colite hemorrágica e síndrome urêmico-hemolítica. Higiene Alimentar, v.13, n.66/67, p.88-89, nov./dez. 1999. 
RODRIGUES, F.T.; VIEIRA, M.D.; SANTOS, J.L. et al. Características do queijo tipo Minas Frescal comercializado em Viçosa-MG. In: CONGRESSO NACIONAL DE LATICÍNIOS, 8., Juiz de Fora, 1995. Anais. Juiz de Fora: EPAMIG, 1995. p.233-235.

ROITMAN, I.; TRAVASSOS, L.R.; AZEVEDO, J.L. Tratado de microbiologia. São Paulo: Mamole, 1988. 2v.

ROSENTHAL, I.; MARTINOT, M.; LINDNER, P. et al. A study of ionizing irradiation of dairy products. Milchwissenschaft, v.38, n.8, p.467-470, 1983.

SABIONE, J.C. Intoxicação alimentar por queijo minas contaminado com S. aureus. Revista Saúde Pública, v.22, n.41, p.458-461, 1993.

SANTOS, E.S.; CARVALHO, E.P.; ABREU, L.R. Psicrotróficos: conseqüências de sua presença em leites e queijos. Boletim da Sociedade Brasileira de Ciência e Tecnologia de Alimentos, v.33, n.2, p.129-138, jul./dez. 1999.

SANTOS, F.A.; NOGUEIRA, N.A.P.; CUNHA, G.M. Aspectos microbiológicos do queijo tipo coalho comercializado em Fortaleza-CE. Boletim Centro de Pesquisa e Processamento de Alimentos, v.13, n.1, p.31-36. jan./jun. 1995.

SARANTÓPOULOS, C.I.G.L; OLIVEIRA, L.M. A embalagem plástica e a conservação de produtos cárneos. Alimentos \& Tecnologia, v.6, n.30, p.86-92, 1990.

SARANTÓPOULOS, C.I.G.L; SOLER, R.M. Embalagens com atmosfera modificada/controlada. Catálogo Brasileiro de Produtos e Serviços. Campinas: ITAL, jul. 1994. p.32-42. 
SARANTÓPOULOS, C.I.G.L. Embalagem a vácuo e com atmosfera modificada para carnes frescas. Embalagem para produtos cárneos. Campinas: ITAL, Centro de Tecnologia de Embalagem de Alimentos, 1991. cap.1, p.1-20.

SARANTÓPOULOS, C.I.G.L.; ALVES, R.M.V.; MORI, E.E.M. et al. Efeitos da embalagem com atmosfera na preservação do queijo parmesão ralada. Coletânea do Instituto de Tecnologia de Alimentos, v.25, n.1, p.67-79, 1995.

SARANTÓPOULOS, C.I.G.L; OLIVEIRA, L.M.; EIROA, M.U. et al. Effect of MAP on quality and shelf-life of buffalo mozzarella cheese. In: IAPRI - WORLD CONFERENCE ON PACKAGING, 8., São Paulo, 1993. Proceedings. Campinas: CETEA, 1993. v.2, p.637-650.

SAS INSTITUTE. SAS user's guide: statistics. 6.ed. Cary, 1988. 584p.

SCHEUSNER, D.L.; HARMON, L.G. Growth and enterotoxin production by various strains of Staphylococcus aureus in selected foods. Journal of Food Science, v.38, n.3, p.474-476, Mar./Apr. 1973.

SCOTT, R.C.; SMITH, H.O. Cottage cheese shelf life and special gas atmospheres. Journal of Food Science, v.36, n.12, p.78-80, 1971.

SCOTT, R. Fabricación de queso. Zaragoza: Acribia, 1991. 520p.

SILVA JUNIOR, E.A. Manual de controle higiênico-sanitário em alimentos. 4.ed. São Paulo: Varela, 2001. 477p. 
SILVA, C.A.M.; LEITÃO, M.F. Influência da temperatura de armazenamento e proliferação microbiana e no tempo de vida útil do queijo tipo "Minas Frescal". In: CONGRESSO BRASILEIRO DE CIÊNCIA E TECNOLOGIA DE ALIMENTOS, 4., Rio de Janeiro, 1980. Resumos. Rio de Janeiro: Sociedade Brasileira de Ciência e Tecnologia de Alimentos, 1980. p.186.

SILVA, J.V.; HOFFMANN, F.L.; MANSOR, A.P. et al. Monitoramento da qualidade microbiológica de queijos tipo "Minas frescal" fabricados artesanalmente. Indústria de Laticínios, v.10, n.24, p.71-75, 2001.

SILVA, N.; JUNQUEIRA, V.C.A.; SILVEIRA, N.F.A. Manual de métodos de análises microbiológicas de alimentos. São Paulo: Varela, 1997. 310p.

SMITH, J.L.; BUCHANAN, R.L.; PALUMBO, S.A. Effect of food environment on staphylococcal enterotoxin synthesis: a review. Journal of Food Protection, v.46, n.6, p.545-555, June 1983.

SMITH, J.; RAMASWAMY, H.; SIMPSON, B. Developments in food packaging technology. Part 2: Storage aspects. Trends Food Science Technology, v.1, n.5, p.111-118, 1990.

SOUZA, J.M.; SILVA, M.C.C.; MARTINS VIEIRA, M.B.C. et al. Avaliação da qualidade microbiológica de queijos comercializados em Belo Horizonte, MG, no período de 1984 a 1991. In: ENCONTRO NACIONAL DE ANALISTAS DE ALIMENTOS, 8., Porto Alegre, 1993. Anais. Porto Alegre: UFRGS, 1933. p.79. 
SOUZA, J.P.; JONG, E.V.; GOULART, H.H.R. Aumente o tempo de conservação dos alimentos e obtenha mais lucros. Porto Alegre: Imprensa Livre, 2001. 112p.

SPECK, M.L. Compendium of methods for the microbiological examination of foods. Washington: APHA, 1992. 421p.

SPEER, E. Lactologia industrial. 2.ed. Zaragoza: Acribia, 1991. 321p.

STECCHINI, M.L.; SARAIS, I.; DEL TORRE M. et al. Effect of electron irradiation and packaging atmosphere on the surival of Aeromonas hydrophila in minced poultry meat. Radiation Physical Chemistry, v.46, n.4-6, p.779784, 1995.

STONE, H.; SIDEL, J.L. Descriptive analysis: In: STONE, H.; SIDEL, J.L. Sensory evalution pratices. London: Academic Press, 1985. p.202-206.

TATINI, S.R.; CORDS, B.R.; GRAMOLI, J. Screening for Staphylococcal Enterotoxins in food. Food Technology, v.30, n.4, p.64-74, Apr. 1976.

TAVARES, L.B.B.; GARCIA, J.A. Ocorrência de coliformes fecais e Escherichia coli em queijo colonial comercializado no município de Blumenau - Estado de Santa Catarina. Boletim Centro de Pesquisa e Processamento de Alimentos, v.11, n.2, p.139-146, jul./dez. 1993.

THAKUR, B.R.; SINGH R.K. Combination process in food irradiation. Trends in Food Science \& Technology, v.6, n.14, p.7-11, 1995. 
TIBANA, A.; RAYMAN, K.; AKHTAR, M.; SZABO, R. Thermal stability of Staphylococcal enterotoxins $A, B$ and $C$ in a buffered system. Journal of Food Protection, v.50, n.3, p.239-242, Mar. 1987.

TRABULSI, L.R.; ALTERTHUM, F.; COMPERTZ, O.F. et al. Microbiologia. 3.ed. São Paulo: Atheneu, 1999. 586p.

VANDERZANT, C.; SPLITTSTOESSER, D.F. Compedium of methods for the microbiological examination of foods. 3.ed. Washington: American Public Health Association (APHA), 1992. 525p.

VIEIRA, S.D.A.; NETO, J.P.M. Elaboração de queijos frescais em pequena escala. Informe Agropecuário, v.8, n.88, p.28-29, 1982.

VOSNIAKOS, F.K.; HATZIIOANNOU, K.A. The preservation and maturing of dairy products by using an irradiation process. Advances in Food Science, v.19, n.1/2, p.8-11, 1997. /Resumo em Food Science and Technology Abstract/

WAGNER, S.C. Alimentos irradiados: uma tendência com grandes perspectivas. Industria Alimentícia, v.30, n.8, p.28-32, 2000.

WANG, G.; ZHAO, T.; DOYLE, M.P. Fate of enterohemorrhagic Escherichia coli O157:H7 in bovine feces. Applied and Environmental Microbiology, v.62, n.7, p.2567-2570, July 1996.

WORLD HEALTH ORGANIZATION (WHO). Safety and nutritional adequacy of irradied food. Rome, 1994. 164p. 
WOSFSCHOON-POMBO, A.F.; FURTADO, M.M.; MUNCK, A.V. Estudo da fabricação do queijo Minas Frescal com ácido lático em substituição ao fermento láctico. In: CONGRESSO NACIONAL DE LATICÍNIOS, 5., Juiz de Fora, 1978. Anais. Juiz de Fora: EPAMIG, 1978. p.161-182.

YÜCEER, S.; GÜNDÜZ, G. Preservation of cheese and plain yogurt by low dose irradiation. Journal of Food Protection, v.43, n.2, p.114-118, 1980. 